UNIVERSIDADE DE SÃO PAULO

FACULDADE DE FILOSOFIA, LETRAS E CIÊNCIAS HUMANAS DEPARTAMENTO DE CIÊNCIA POLÍTICA PROGRAMA DE PÓS-GRADUAÇÃO EM CIÊNCIA POLÍTICA VICTOR AUGUSTO ARAÚJO SILVA

Mecanismos de Alinhamento de Preferências em Governos Multipartidários: Controle de Políticas Públicas no Presidencialismo Brasileiro 


\section{Mecanismos de Alinhamento de Preferências em Governos Multipartidários: Controle de Políticas Públicas no Presidencialismo Brasileiro}

Dissertação apresentada ao programa de pósgraduação do Departamento de Ciência Política da Universidade de São Paulo, como requisito para a obtenção do título de Mestre em Ciência Política.

Orientador: Prof. Dr. Fernando de Magalhães Papaterra Limongi

SÃO PAULO 


\section{FOLHA DE APROVAÇÃO}

Autor: Victor Augusto Araújo Silva

Título: Mecanismos de Alinhamento de Preferências em Governos Multipartidários: Controle de Políticas Públicas no Presidencialismo Brasileiro.

Dissertação apresentada ao programa de pósgraduação do Departamento de Ciência Política da Universidade de São Paulo, como requisito para a obtenção do título de Mestre em Ciência Política.

Aprovada em:

Banca examinadora:

Prof(a). Dr

Julgamento:

Prof(a). Dr

Julgamento:

$\operatorname{Prof}(\mathrm{a}) . \operatorname{Dr}$

Julgamento:
Instituição:

Assinatura:

Instituição:

Assinatura:

Instituição:

Assinatura: 
Ao meu primo e melhor amigo Leonardo Figueira (in memorian) 


\section{Agradecimentos}

Este trabalho é um resultado da generosidade, carinho, paciência e amor de várias pessoas comigo. Em primeiro lugar, agradeço aos meus pais (Laura e Vitório), irmão (Raphael) e avô (Vitório) pelo suporte psicológico e logístico. Agradeço por suportarem as minhas muitas ausências, inconstâncias e recorrentes despedidas. À Luiza, a minha melhor amiga nos últimos tempos, devo enorme gratidão pelo amor e carinho.

No âmbito acadêmico, sou grato a muitos parceiros. Primeiramente, devo manifestar a minha enorme gratidão ao meu orientador, Fernando Limongi. Na minha trajetória de 1/4 de século de vida, poucas pessoas foram comigo tão generosas, leais e disponíveis. Agradeço por você ter extraído o melhor que eu poderia dar, sem, contudo, desconsiderar as minhas fraquezas e limitações de ser humano. Foi um privilégio poder tirar lições da convivência com um exímio pesquisador e, acima de tudo, uma pessoa de brio e caráter.

Aos meus colegas do NECI, em especial Andréa Freitas, Maurício Izumi (Samurai) e Joyce Luz, sou grato pelas prosas, divergências, críticas, dicas e momentos juntos. A Andréa Freitas, devo especial gratidão pela confiança e pelas muitas horas "investidas" no meu trabalho. Sem as suas pitadas diárias de desconfiança e sagacidade a qualidade deste trabalho seria muito inferior. Devo também especial agradecimento a Paulo Hubert, nosso estatístico/programador/pesquisador/cantor/poeta que gentilmente me ajudou com tecnicalidades em vários momentos do desenvolvimento da minha pesquisa. Por minha culpa, Paulo, você nunca mais irá esquecer o termo "RIC". Sou grato ainda aos meus colegas pesquisadores Diego Corrêa, Fernanda Machado, Andréa Junqueira, Ana Beatriz, Leonardo Diegues, Alexia Aslan, Leonardo Barone, Samuel Moura e Danilo Medeiros.

A Juliana Oliveira, o meu anjo da guarda durante o mestrado, devo um agradecimento especial. Muito obrigado pela sua dedicação, seriedade e amizade durante o tempo em que trabalhamos juntos. Ninguém esteve tão entusiasmada - mesmo fazendo um trabalho muito chato de coleta de dados - com este projeto de pesquisa quanto você. Vibrou com cada gráfico, artigo ou modelo que conseguíamos fazer. Chorou comigo também algumas vezes e me encorajou a seguir em frente. Merci, Julliette! 
Agradeço aos professores Magna Inácio, Bruno P.W Reis, Jerônimo Muniz, Glauco Peres da Silva (Glauco), Rogério Arantes, Bruno Speck, Manoel Leonardo Santos, Royce Carroll e Carlos Eduardo Guerra pelos conselhos e ajuda em várias oportunidades. À professora Marta Arretche, devo um agradecimento especial pelo tempo investido na minha formação durante o mestrado. Em inúmeras ocasiões, abdicou de outras atividades e compromissos para me instruir, admoestar e, quando foi preciso, me colocar novamente nos trilhos.

Aos amigos Luciano Cunha (Diamond), Adualdo Rodrigues (Du), Marco Antônio Soares, Thiago Silva, Marcelo Vieira, Júlio Cesar, Bruno Arcas, Lucas Cunha, Alessandra Costa, Felipe Lima Eduardo, Filipe Corrêa, Nathália Porto e Natalia Bueno agradeço pelas excelentes conversas à distância, lições, e boas vibrações enviadas para que este trabalho se concretizasse.

Agradeço também aos meus colegas de departamento Thiago Oliveira, Thiago Moreira, Vitor Diniz, Daniela Constanzo, Mona Oliveira, Marcos Campos, Hellen Guicheney, Sergio Simoni, Paulo Flores, Eduardo Lazzari, Lucas Petroni, Thais Camargo e Natália Moreira. Devo um agradecimento especial a Stefania Cantoni, a melhor companheira para todos os momentos, e a Andressa Matias, pela revisão cuidadosa do texto.

Por fim, agradeço ao Bernardo Araújo, o bebê mais lindo e charmoso do mundo, que conseguiu a proeza de roubar sorrisos e suspiros meus nos últimos instantes deste trabalho de mestrado, um período, como muitos sabem, solitário e doloroso. 
"Existem duas maneiras de um teórico se desviar do caminho: 1. O diabo o guia pelo nariz com uma falsa hipótese (por isso, ele merece piedade); 2. Seus argumentos são equivocados e ridículos (por isso, ele merece uma surra)". (Albert Einstein, 1915).

"[.]Politics is a contest where some gain the authority to make decisions of fundamental significance for others[...] Given this, the center of story is not elections but policy. For most of those engaged in politics over sustained periods, elections are only a means to an end: control over authority, or the capacity to make policies. (Hacker \& Pierson, 2010). 


\section{Resumo}

O principal objetivo deste trabalho é mostrar que, no presidencialismo multipartidário brasileiro, as políticas públicas implementadas pelo Executivo são resultantes do processo de agregação de preferências dos diferentes atores partidários que integram o gabinete de governo. Posto que os partidos aceitam integrar coalizões de governo em função da expectativa de agregar suas preferências à agenda de políticas do Executivo, os conflitos intragabinete são derivados da não efetivação desta expectativa. Argumento que, embora sejam delegadas aos integrantes do gabinete áreas ministeriais específicas, os partidos da coalizão monitoram as áreas de policy dos seus parceiros de governo, na tentativa de diminuir a assimetria de informação e agregar suas preferências às políticas que lhes interessam. Para tanto, investigo de que forma os parlamentares utilizam as suas prerrogativas de controle horizontal - [i] Requerimentos de Informação (RIC), [ii] Propostas de Fiscalização e Controle (PFC) e [iii] Projeto de Decreto Legislativo (PDC) - para obter informações sobre a implementação de políticas nos ministérios dos partidos parceiros do gabinete. A análise compreende o período entre 1995 e 2014, nos governos Fernando Henrique Cardoso (FHC), Luís Inácio da Silva (LULA) e Dilma Rousseff (DILMA). As evidências apresentadas neste trabalho sugerem que a taxa de controle horizontal intragabinete varia positivamente com o grau de dispersão de preferências dos partidos representados no governo. Em função da motivação policyseeking dos atores que integram o gabinete, os partidos que possuem mais recursos para a implementação de políticas públicas são também aqueles que recebem o maior volume de controle dos seus parceiros de gabinete. Como consequência, são os partidos da coalizão de governo os principais responsáveis por monitorar as ações de implementação de políticas públicas do Executivo. Ao contrário do que ocorre no momento de formulação das políticas no gabinete e no parlamento, o peso legislativo dos partidos integrantes do governo importa pouco para a capacidade destes atores agregarem suas preferências às policies. Isso explica o que ganham os partidos que aceitam integrar as coalizões de governo e revela qual o mecanismo que viabiliza a manutenção de um pacto político firmado entre atores com preferências distintas e heterogêneas. 


\section{Abstract}

The aim of this study is to show that public policies implemented by the executive branch in the Brazilian multiparty presidential system are the result of aggregating the preferences of different party members within the government cabinet. Parties agree to integrate into the coalition government because they expect to be able to add their preferences to the government policy agenda. However, when parties are unable to influence the policy agenda, it often results in intra-cabinet conflicts. I argue that, although the chief executive delegates specific portfolios to each cabinet member, the parties scrutinize the policies carried out by the government members in an attempt to reduce the asymmetric information and add their preferences to policies that concern them. For this purpose, I investigate how legislative membres use their horizontal control prerogative - [i] Requerimentos de Informação (RIC), [ii] Propostas de Fiscalização e Controle (PFC) e [iii] Projeto de Decreto Legislativo (PDC) - to obtain information on the policy process of policy implementation within the portfolios held by cabinet members. This study analyzes data from 1995 to 2014, in the Fernando Henrique Cardoso (FHC), Luís Inácio da Silva (LULA) and Dilma Rousseff (DILMA) administrations. The evidence presented in this study suggests that the intra-cabinet horizontal control varies positively with the degree of dispersion of policy preferences in the cabinet government. As a result of the policy-seeking motivation of the actors who comprise the government coalition, parties with more resources for the implementation of public policies are also those that receive the greatest amount of control over other members of the cabinet. Thus, the government coalition parties are primarily responsible for monitoring the implementation of federal programs. Unlike what is observed at the time of policy formulation in the cabinet and in parliament, the proportion of coalition seats/votes a member contributed is of small importance to the ability of these actors to aggregate their prefered policies. This explains what the parties receive when they agree to integrate into the cabinet and reveals the mechanism that enables the maintenance of a political pact between actors with different and heterogeneous preferences. 


\section{Resumen}

El principal objetivo de este trabajo es mostrar que, en el presidencialismo multipartidista brasileño, las políticas públicas implementadas por el Poder Ejecutivo son resultado del proceso de agregación de preferencias de los diferentes actores partidarios que conforman el gabinete de gobierno. Dado que los partidos aceptan integrar coaliciones de gobierno en función de la expectativa de agregar sus preferencias a la agenda del Ejecutivo, los conflictos intra-gabinete derivan del no cumplimiento de tal expectativa. Argumento que, a pesar de que sean delegadas a los integrantes del gabinete áreas ministeriales específicas, los partidos de la coalición monitorean las áreas de policy de sus socios del gobierno, en el intento de reducir la asimetría de información y agregar sus preferencias a las políticas que les interesan. Para ello, investigo de qué forma los parlamentarios utilizan sus prerrogativas de control horizontal - [i] Requerimentos de Informação (RIC), [ii] Propostas de Fiscalização e Controle (PFC) e [iii] Projeto de Decreto Legislativo (PDC) - para obtener informaciones sobre la implementación de políticas en los ministerios de los partidos socios del gobierno. El análisis comprende el período entre 1995 y 2014, en los gobiernos de Fernando Henrique Cardoso (FHC), Luís Inácio da Silva (LULA) y Dilma Rousseff (DILMA). Las evidencias presentadas en este trabajo sugieren que la tasa de control horizontal intra-gabinete varía positivamente con el grado de dispersión de las preferencias de los partidos representados en el gobierno. En función de la motivación policy-seeking de los actores que integran el gabinete, los partidos que poseen más recursos para la implementación de políticas públicas son también aquellos que reciben el mayor volumen de control de sus socios de gabinete. Como consecuencia, son los partidos de la coalición de gobierno los responsables principales por monitorear las acciones de implementación de políticas públicas del Ejecutivo. Contrariamente a lo que ocurre en el momento de formulación de las políticas en el gabinete y en el Parlamento, el peso legislativo de los partidos integrantes del gobierno poco importa para la capacidad que tienen estos actores de agregar preferencias a las policies. Esto explica qué ganan los partidos que aceptan integrar coaliciones de gobierno y revela cuál es el mecanismo que viabiliza el mantenimiento de un pacto político firmado entre actores con preferencias distintas y heterogéneas. 


\section{Lista de Gráficos}

Gráfico 1.1. Grau de verticalização do processo de tomada de decisão no gabinete em 55 democracias por sistema de governo.

Gráfico 1.2. Boxplot do grau de verticalização do gabinete por sistema de governo.

Gráfico 3.1. Variação do número de requerimentos de informação em função do grau de heterogeneidade ideológica do gabinete de governo (19952014) . .44

Gráfico 3.2. Áreas ministeriais monitoradas pelos partidos via requerimento de informação (RIC), nos governos FHC, LULA e DILMA (1995 -2014).

Gráfico 3.3. Tema das ações de controle realizadas pelos partidos via requerimento de informação (RIC), nos governos FHC, LULA e DILMA (1995 - 2014)

Gráfico 3.4. Nível de agregação das ações de controle realizadas pelos partidos via requerimento de informação (RIC), nos governos FHC, LULA e DILMA (19952014).

Gráfico 4.1. Variação do número de Propostas de Fiscalização e Controle (PFC) em função do grau de heterogeneidade ideológica do gabinete de governo (19952014)

Gráfico 4.2. Variação do número de Projetos de Decreto Legislativo (PDC) em função do grau de heterogeneidade ideológica do gabinete de governo (20002014).

Gráfico 5.1. Participação na agendo do Executivo por partido e governo (1995-2014). 109

Gráfico 5.2. Participação nas modificações (dispositivos) das propostas de políticas do Executivo por partido e governo (1995-2010). 112

Gráfico 5.3. Participação nas ações de controle - via requerimento de informação - de implementação das políticas públicas do Executivo por partido e governo (19952014) 114

Gráfico 5.4. Influência dos partidos da coalizão de governo nas arenas de agregação de preferências, de acordo com o peso legislativo. 117 


\section{Lista de Tabelas}

Tabela 1.1. Teste de Tukey (análise de variância) - entre sistemas de governo. .29

Tabela 2.1. Características dos gabinetes formados no Brasil (1995 -2014)................................40

Tabela 3.1. Descritivas das redes de controle horizontal (RIC)..................................................50

Tabela 3.2. Descritivas das variáveis utilizadas nos modelos Logit e

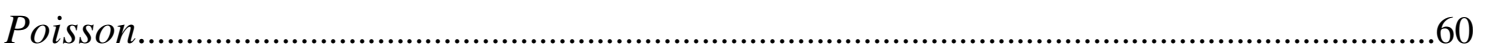

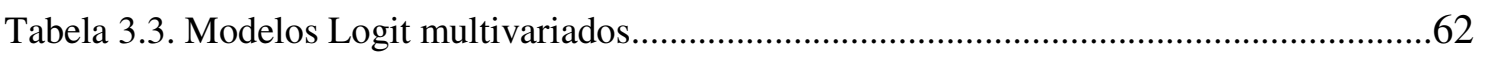

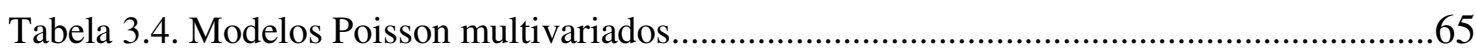

Tabela 3.5. Teste de Tukey (análise de variância) - proporção de controle (RIC) executado pela coalizão em cada governo (FHC, LULA e DILMA).

Tabela 3.6. Posição dos atores nas redes de controle horizontal (FHC, LULA e

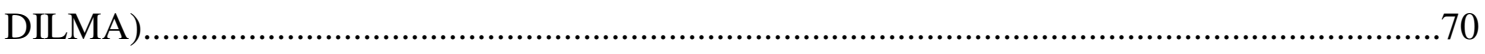

Tabela 3.7. Grau de centralidade nas redes de controle horizontal em função do volume de

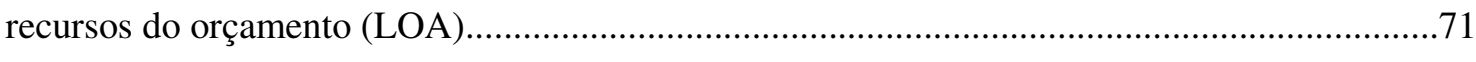

Tabela 3.8. Participação dos partidos da coalizão nas ações de controle por área ministerial e

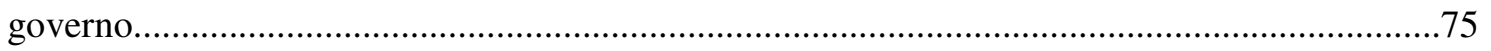

Tabela 3.9. Participação dos partidos da coalizão nas ações de controle por temática e governo.......

Tabela 3.10. Participação dos partidos da coalizão nas ações de controle por nível e governo.

Tabela 4.1. Descritivas das redes de controle horizontal (PFC)...

Tabela 4.2. Teste de Tukey (análise de variância) - proporção de Controle (PFC) executado pela coalizão em cada governo (FHC, LULA e DILMA). .91

Tabela 4.3. Descritivas das redes de controle horizontal (PDC). .95

Tabela 4.4. Teste de Tukey (análise de variância) - proporção de Controle (PDC) executado pela coalizão em cada governo (FHC, LULA e DILMA). 96

Tabela 5.1. Partidos, arenas e payoffs variáveis (1995-2014) 116 


\section{Lista de Figuras}

Figura 3.1. Redes de média densidade

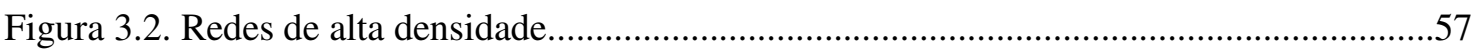

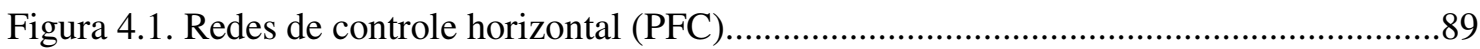

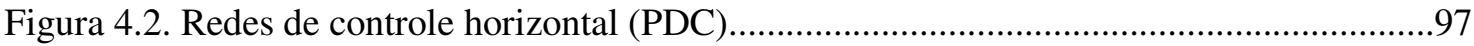

Figura 5.1. Cadeia de interação entre $n$ partidos que integram $o$

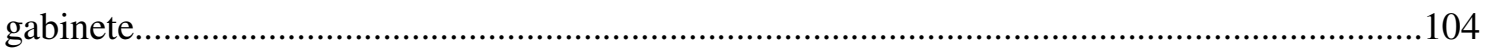

Figura 5.2. Cadeia de interação entre $n$ partidos que integram $o$

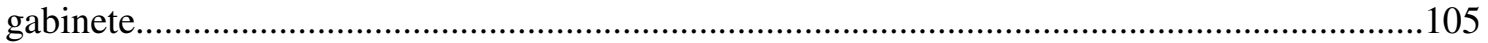




\section{Lista de Apêndices}

Apêndice A. Cálculo do grau de heterogeneidade do gabinete.

Apêndice B

Figura B.1. Redes de baixa densidade.

Apêndice C. Cálculo do grau de centralidade do ator na rede.

Apêndice D

Tabela D.1. Áreas de policy do partido formador e do principal parceiro do gabinete

Apêndice E

Quadro E.1. Exemplos dos requerimentos de informação (RIC) utilizados para compor as categorias da dimensão "Temática".....

Apêndice F

Quadro F.1. Exemplos do dos requerimentos de informação (RIC) utilizados para compor as categorias da dimensão "Nível".

Apêndice G

Tabela G.1. Partidos do gabinete e peso legislativo por governo. 


\section{Lista de Abreviaturas e Siglas}

DEM Democratas

PAN Partido dos Aposentados da Nação

PCdoB Partido Comunista do Brasil

PDT Partido Democrata Trabalhista

PL Partido Liberal

PMDB Partido do Movimento Democrático Brasileiro

PMN Partido da Mobilização Nacional

PPB Partido Progressista Brasileiro

PP Partido Progressista

PPS Partido Popular Socialista

PR Partido Republicano

PRB Partido Republicano Brasileiro

PRONA Partido da Reedificação da Ordem Nacional

PSB Partido Socialista Brasileiro

PSC Partido Social Cristão

PSDB Partido da Social Democracia Brasileira

PSOL Partido Socialismo e Liberdade

PT Partido dos Trabalhadores

PTB Partido Trabalhista Brasileiro

PV Partido Verde 


\section{Sumário}

Introdução 17

1. Incentivos formais para a distribuição de recursos para policy em governos multipartidários presidencialistas.

2. Delegação em governos com múltiplas preferências: gabinetes multipartidários no presidencialismo brasileiro. 34

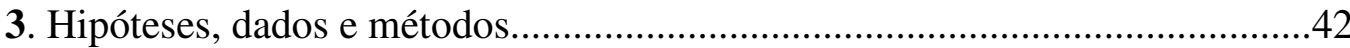

3.1. Hipóteses 42

3.2. Controle horizontal de políticas públicas via requerimento de informação (RIC)

3.3. As redes de controle horizontal no presidencialismo brasileiro.......46

3.4. Determinantes do controle horizontal - via RIC - no presidencialismo brasileiro .59

3.5. O que têm os partidos controlados: atributos dos atores partidários nas redes de controle horizontal

3.6. Análise do conteúdo das ações de controle: quais as áreas e os temas controlados pelos partidos da coalizão? .72

4. Evidências alternativas de controle horizontal em gabinetes multipartidários no Brasil.

5. Implicações teóricas e empíricas do controle da implementação de políticas públicas. 101

5.1. Parâmetros do modelo 102

5.1. Implicações do modelo para a estratégia dos partidos. 103

5.3. Partidos e coalizões de governo no Brasil: um jogo de múltiplas arenas e payoffs variáveis 105

Conclusão 116

Referências 121 


\section{Introdução}

O objetivo fundamental deste trabalho é analisar de que forma os partidos que integram o gabinete de governo monitoram o processo de implementação para influenciar as diversas áreas de política do Executivo. $\mathrm{O}$ pressuposto que norteia a presente análise é o de que os partidos integram o governo para agregar suas preferências às políticas do gabinete. Esse pressuposto possui duas implicações fundamentais para os objetivos deste trabalho: [a].os conflitos intragabinete são decorrentes da disputa por recursos para a implementação de políticas públicas e; [b].esses conflitos se expressam na arena parlamentar.

Nesse sentido, o pacto que sustenta o acordo político entre os partidos que aceitam integrar o governo, assumindo todos os riscos e dividendos embutidos nessa escolha, é baseado na expectativa desses autores de formular e implementar políticas o mais próximo possível do seu ponto ideal de policy. Essa motivação dos partidos para influenciar as políticas do Executivo foi absolutamente desconsiderada pelas primeiras gerações de estudos sobre o presidencialismo.

A análise realizada por Juan Linz (1990) lançou as bases para um entendimento equivocado da relação Executivo-Legislativo nas democracias presidencialistas. De acordo com este autor, o fato de o chefe do Executivo possuir um mandato fixo e independente da confiança do parlamento torna o presidencialismo um sistema rígido, onde Executivo e Legislativo competem por legitimidade. Desse modo, não haveria incentivos para a cooperação entre os dois Poderes, e, muito menos, incentivos para composição de coalizões de governo.

Ainda de acordo com o autor, se nos sistemas parlamentaristas a interdependência entre os dois poderes fomenta a composição de uma agenda única de políticas, no presidencialismo, apenas um dos lados pode sagrar-se vitorioso ${ }^{1}$. Em outros termos, se não existe cooperação entre os dois Poderes, as políticas públicas só podem ser resultantes das medidas unilaterais tomadas pelo chefe do Executivo e/ou da aceitação passiva do parlamento das propostas formuladas pelo presidente ${ }^{2}$.

\footnotetext{
${ }^{1}$ Esse efeito é denominado Winner-takes-all (politics) pelo autor.

${ }^{2}$ Seguindo o raciocínio do autor, se Executivo e Legislativo divergem acerca de uma determinada proposta de política, ocorre paralisia decisória. Esse constante incentivo para a paralisia está, de acordo com Linz (1990), relacionado com a pouca estabilidade verificada nos regimes presidencialistas latinoamericanos.
} 
Não obstante a seleção de casos pela variável dependente, a desconsideração dos possíveis impactos do sistema partidário e eleitoral e do evidente problema de endogeneidade ${ }^{3}$ presente em sua análise (Horowitz, 1990), a formulação oferecida por Juan Linz deixou marcas indeléveis no campo da política comparada. As análises subsequentes, ainda que com maior nível de rigor e incorporação de mais variáveis, seguiram a tendência de caracterizar o regime presidencialista enquanto sistema com um modus operandi não cooperativo. Ou seja, um sistema em que a relação ExecutivoLegislativo seria sustentada pelas relações de patronagem entre o chefe do Executivo e os partidos integrantes do gabinete.

Shugart \& Carey (1992) argumentam que a existência de dois agentes do eleitorado - uma assembleia e um presidente - que competem entre si seria a característica distintiva do sistema presidencialista. Para os autores, o elemento não cooperativo deste sistema seria explicado pela existência de presidentes com amplos poderes legislativos. Presidentes fortes - atores com muitas prerrogativas para a tomada de decisão unilateral - seriam estimulados a desconsiderar as preferências dos atores representados no Poder Legislativo.

Nos presidencialismos latino-americanos, o incentivo para a ação unilateral dos presidentes seria reforçado pela baixa disciplina partidária dos atores no legislativo e a não predisposição destes para decidir sobre temas de importância nacional ${ }^{4}$. Mainwaring (1993) e Mainwaring \& Shugart (1997) incluíram nessa conta os riscos provenientes do multipartidarismo. Num sistema pautado pela lógica não cooperativa entre os Poderes e pela falta de incentivo para a formação de coalizões governativas, presidentes suportados por minorias legislativas não teriam alternativa senão implementar a sua agenda de políticas unilateralmente.

Uma segunda geração de estudos não apenas contestou a utilização da variável "sistema de governo" como sendo capaz de predizer a capacidade de tomada de decisão (Tsebelis, 1995), como também demonstrou a existência de incentivos para a formação de coalizões de governo (Cheibub; Limongi, 2002, Cheibub; Przeworski; Saiegh, 2004,

\footnotetext{
${ }^{3}$ Os sistemas presidencialistas são menos estáveis ou os sistemas presidencialistas foram adotados em contextos políticos de menor estabilidade? Está uma questão inteiramente negligenciada pelo autor.

${ }^{4} \mathrm{O}$ que os autores denominam "Segredo Ineficiente" numa alusão ao termo "Segredo Eficiente", utilizado por Cox (1987) para explicar, na Inglaterra do período vitoriano (séc. XIX), o papel do gabinete na centralização da atividade legislativa, viabilizando a aprovação de políticas de interesse nacional, embora o sistema eleitoral majoritário produzisse incentivos para a representação de interesses locais. Amorim Neto \& Santos (2003) refutam parcialmente a aplicação do argumento do "Segredo Ineficiente" no caso brasileiro.
} 
Cheibub, 2007), para o comportamento disciplinado dos partidos no Legislativo (Figueiredo; Limongi, 2000), além de rechaçar a hipótese de que o multipartidarismo seria condição suficiente para a instabilidade política observada nos presidencialismos da América Latina (Power; Gasiorowski, 1997).

Esses estudos foram de fundamental importância para a erosão do argumento de que presidencialismos não poderiam funcionar sem crise e rupturas da ordem democrática. Todavia, os argumentos mobilizados por essa corrente em favor da governabilidade em sistemas presidencialistas foram também pautados nas capacidades excepcionais do chefe do Executivo.

O mecanismo explicativo utilizado por Figueiredo \& Limongi (1995) para explicar as altas taxas de sucesso legislativo do Executivo brasileiro se assenta, em grande medida, nas prerrogativas constitucionais que conferem ao presidente a capacidade de controlar a agenda legislativa. $\mathrm{O}$ presidente, enquanto agente da maioria, seria o ator responsável por coordenar as ações da coalizão de governo, fornecendo para o gabinete e os partidos representados no Legislativo os inputs necessários para a aprovação da agenda de políticas do Executivo. Dentro dessa perspectiva, tanto o poder de agenda do presidente (idem, 1999) quanto a prerrogativa de formular e propor o orçamento federal (Limongi; Figueiredo, 2005, 2008), são considerados mecanismos para resolver os conflitos internos da coalizão e para viabilizar um pacto cooperativo entre Executivo e Legislativo - em torno da formulação e implementação de políticas públicas.

Embora reconheçam o objetivo dos partidos de influenciar a agenda de políticas do Executivo, o modelo analítico utilizado pelos autores é centrado no cálculo do presidente, desconsiderando as estratégias utilizadas pelos partidos do gabinete para agregar as suas preferências em distintas arenas. É bem verdade que o acordo cooperativo sugerido pelos autores pressupõe consequências comportamentais dos atores. Isto é, a distribuição de portfólios no Executivo viabiliza um acordo político estável que garante apoio legislativo às propostas do Executivo votadas em plenário. Todavia, não há indicações de como esse acordo se mantém no tempo e nem de como os conflitos internos do gabinete influenciam o processo de formulação das políticas do governo.

Ainda na segunda geração de estudos sobre o presidencialismo, Amorim Neto (2000) apresenta uma leitura office-seeking da cooperação existente entre Executivo e Legislativo. Para esse autor, os dispositivos constitucionais garantidores da tomada de 
decisão unilateral do presidente explicariam a falta de incentivos para a distribuição proporcional de recursos em gabinetes presidencialistas. A prerrogativa do chefe do Executivo para nomear e demitir os ministros do gabinete a qualquer tempo é interpretada como a principal razão para que os partidos da coalizão de governo aceitem receber uma quantidade de recursos para a implementação de políticas inferior ao seu peso legislativo. Ademais, a composição do gabinete seria uma função apenas da estratégia do chefe do gabinete para implementar o seu portfólio de políticas. Por esse raciocínio, presidentes constitucionalmente fortes poderiam, inclusive, optar exclusivamente pela via unilateral de tomada decisão, adotando a estratégia de compor gabinetes minoritários e menos partidarizados (idem, 2006).

No modelo sugerido por esse autor e por outros trabalhos que o sucederam (Melo; Pereira, 2013; Raile; Pereira; Power, 2011; Chaisty; Cheeseman; Power, 2014), a relação de cooperação entre os dois Poderes é instável e sustentada pela operação permanente de compra de apoio político. Dessa forma, essas análises acabaram por reforçar uma visão estereotipada do presidencialismo segundo a qual os partidos são pautados exclusivamente pela orientação office-seeking. A simples correlação entre a distribuição de cargos e o apoio dos partidos no parlamento tem sido interpretada como uma prova cabal de que o acordo político entre os membros da coalizão é fundamentado em relações de patronagem.

No limite, assume-se que não existe uma agenda do Executivo, mas uma agenda de políticas do presidente que é concretizada através de acordos escusos, sendo desconsideradas por completo as preferências dos partidos que ocupam o gabinete, e, quando consideradas, associadas unicamente aos retornos eleitorais que os partidos podem obter ocupando cargos no Executivo.

O presente trabalho é um empreendimento teórico e empírico que pretende mostrar que os conflitos observados em gabinetes presidencialistas multipartidários são decorrentes do objetivo dos partidos de influenciar as políticas do Executivo. Busca-se, na esteira do que prescrevem Cheibub \& Limongi (2010), mostrar que a relação entre os Poderes no presidencialismo não é um jogo de soma zero, em que o sucesso do Executivo ocorre às expensas do Legislativo, mas uma relação de cooperação estável no tempo e sustentada pela oportunidade dos partidos que integram o gabinete agregarem suas preferências às políticas públicas.

A relação de cooperação entre Executivo-Legislativo só é possível se há a transferência de capacidade para influenciar as políticas do Executivo. Os partidos da 
coalizão de governo não agem apenas reativamente negando apoio às proposições do Executivo em situações de conflito, eles também atuam proativamente ao tentar agregar suas preferências às políticas do governo no momento da formulação e da implementação das políticas públicas.

Argumento que, no caso brasileiro, os partidos da coalizão de governo, via Poder Legislativo, controlam as ações de implementação de políticas públicas dos parceiros do gabinete para mitigar os problemas provocados pela delegação em governos multipartidários. A intensidade das ações de controle varia em função do grau de heterogeneidade das preferências partidárias representadas no Executivo. Nos gabinetes onde a distância entre as preferências do partido formador e as preferências dos partidos parceiros é maior, existem maiores incentivos para a prática do controle mútuo entre os partidos. Esse fato se deve tanto à expectativa de um cenário de desalinhamento entre as preferências do partido do chefe de governo e os seus parceiros políticos, quanto à tendência de cada partido da coalizão tentar agregar suas preferências às áreas ministeriais capitaneadas por outros partidos que compõem o Executivo.

Delegar a terceiros a tarefa de coordenar policies amplia o espectro das áreas que o governo pode atuar simultaneamente, no entanto, abre a possibilidade de que os resultados das políticas em cada área sejam um produto apenas das escolhas do partido que a conduz, em detrimento das preferências dos demais integrantes do gabinete. Nesse sentido, apesar do partido responsável por uma dada área de policy sempre ser mais bem informado acerca das políticas que o seu ministério coordena e executa - essa é uma consequência inexorável da relação de delegação que se processa entre o chefe de governo, seus ministros e a burocracia de cada ministério (Lupia, 2003; Lupia; McCubbins, 1998; McCubbins, 1985) -, os partidos não são indiferentes às áreas de políticas controladas por outros atores e buscam informações sobre as ações empreendidas por seus parceiros do gabinete (Thies, 2001).

O controle mútuo entre os integrantes do gabinete é uma forma de compensar a perda de informação ensejada pela relação de delegação, através do monitoramento das políticas públicas implementadas pelos parceiros de governo. Esse argumento não é propriamente novo. Martin e Vanberg (2011), investigando diversos contextos multipartidários parlamentaristas, encontram evidências de controle mútuo entre os partidos da coalizão. De acordo com os autores, os partidos recorrem à revisão das leis no parlamento para corrigir eventuais desvios dos ministros da agenda de políticas do governo. 
Analisando 19 democracias parlamentaristas com governos multipartidários, Carroll e Cox (2012) mobilizam o mesmo argumento para mostrar como os partidos da coalizão fazem uso das comissões parlamentares para monitorar as políticas elaboradas pelos seus parceiros de gabinete. Na mesma esteira, Freitas (2013) e Inácio e Rezende (2015) apresentam evidências de controle cruzado entre os parceiros da coalizão durante o processo legislativo no Congresso brasileiro. Os parlamentares, como asseveram as autoras, utilizam as comissões, as reuniões em plenário e outros institutos do processo legislativo para influenciar as políticas gestadas nos ministérios ocupados pelos partidos da coalizão.

A contribuição da presente análise é mostrar de que forma os conflitos intragabinete se traduzem em ações de controle de políticas públicas. Ao invés de focar na análise do processo de controle político das propostas de Leis, investigo de que forma os parlamentares utilizam as suas prerrogativas de controle horizontal instrumentos do Poder Legislativo para controle das ações do Poder Executivo - para obter informações sobre a implementação de políticas nos ministérios dos parceiros do gabinete. Para tanto, utilizo como medidas de controle horizontal três instrumentos de correção de assimetria de informação à disposição dos congressistas brasileiros: [a] Requerimentos de Informação (RIC), [b] Propostas de Fiscalização e Controle (PFC) e [c] Projeto de Decreto Legislativo (PDC). A análise compreende o período entre 1995 e 2014, nos governos Fernando Henrique Cardoso (FHC), Luís Inácio da Silva (LULA) e Dilma Rousseff (DILMA).

As evidências encontradas sugerem que a taxa de controle horizontal intragabinete varia positivamente com o grau de dispersão de preferências sobre policy dos partidos representados no governo. Isto é, o que explica a formação dessas redes de monitoramento é a motivação dos partidos para influenciar as políticas. Por essa razão, os partidos que possuem mais recursos para a implementação de políticas públicas são também aqueles que recebem o maior volume de controle dos seus parceiros de gabinete.

A apresentação dos argumentos teóricos, das hipóteses de trabalho, dos testes empíricos e das implicações da análise empreendida se dará através de cinco capítulos. No primeiro capítulo (1), apresento uma revisão crítica da tese da tomada de decisão vertical em gabinetes presidencialistas, argumentando de que maneira a utilização de um pressuposto equivocado tem prejudicado o entendimento das relações que se processam entre os partidos que integram o Executivo. Os elementos apresentados neste 
capítulo fornecem o substrato teórico que justifica a análise empírica empreendida nos capítulos subsequentes deste trabalho.

Posteriormente, no segundo capítulo (2), apresento as implicações da composição de governos multipartidários para a distribuição de recursos para policy. Argumento que existem conflitos inerentes ao processo de delegação em gabinetes com múltiplas preferências. No terceiro capítulo (3), apresento evidências empíricas de que esses conflitos se expressam no Legislativo. Mostro que os partidos utilizam a fase de implementação de políticas públicas para obter informação e influenciar as áreas ministeriais capitaneadas pelos partidos parceiros da coalizão. Através do uso dos requerimentos de informação (RIC) - instrumento legislativo de controle horizontal -, na tentativa de agregar suas preferências, os partidos monitoram as políticas públicas implementadas pelos parceiros da coalizão.

No quarto capítulo (4), apresento evidências alternativas de que o controle sobre políticas públicas executadas pela coalizão se intensifica em governos com preferências dispersas. Mostro que a utilização das propostas de fiscalização e controle (PFC) e do projeto de decreto legislativo (PDC) - outros instrumentos legislativos de controle horizontal - segue o mesmo padrão dos requerimentos de informação. Como cosequência da análise empírica empreendida, no quinto capítulo (5), mostro os ganhos relativos dos partidos da coalizão em cada uma das arenas de agregação de preferências. A consideração da influência que os partidos do gabinete exercem sobre a fase de implementação é crucial para entender o cálculo por trás da decisão dos partidos de compor o Executivo. Por fim, apresento as conclusões e discuto os limites dos modelos derivados da teoria da delegação para dimensionar a capacidade de influência dos partidos sobre os resultados das políticas públicas. 


\section{CAPÍTULO 1}

Incentivos formais para a distribuição de recursos para policy em governos multipartidários presidencialistas

Por muito tempo, foram hegemônicos os juízos em favor da grande dessemelhança no processo de tomada de decisão em sistemas presidencialistas e parlamentaristas. A separação formal de poderes foi utilizada para embasar o argumento em favor de um modelo colegiado (horizontal) de decisão em sistemas parlamentaristas e, em outro extremo, um modelo verticalizado (autárquico) de formulação de políticas em gabinetes presidencialistas. Enquanto, no parlamentarismo, o primeiro ministro seria apenas um entre iguais no gabinete (primus inter pares), no presidencialismo, o governo seria exercido exclusivamente (sole executivo) pelo presidente (Verney, p. 35, 1992).

Sartori (1997) vai ainda mais longe e assevera que essa seria uma característica fundamental para a diferenciação dos dois sistemas de governo. Dado que o presidente nomeia e demite os ministros discricionariamente, sistemas presidencialistas deveriam ser identificados enquanto regime de governo em que o chefe do Executivo dirige os governos que nomeia. Em outros termos, "o poder Executivo seria investido em uma única pessoa" (Lijphart, pag.7, 1992).

Visto que o Primeiro Ministro depende da confiança dos parlamentares, segue que as propostas de políticas do governo precisariam necessariamente levar em consideração as preferências dos atores representados no gabinete. Isso porque as decisões colegiadas no parlamentarismo seriam consequência da existência de uma agenda única entre parlamento e gabinete. Nesse caso, as regras formais do sistema parlamentarista de governo induziriam à distribuição proporcional - em função do peso legislativo de cada partido que ocupa o gabinete - de recursos para a implementação de políticas públicas.

No caso do presidencialismo, em virtude da prerrogativa do presidente para demitir todo o gabinete a qualquer tempo sem prejuízo do seu mandato, as políticas não precisariam refletir as preferências de outros atores além do partido formador do gabinete (partido do presidente). De acordo com Amorim Neto (2000),

como nos sistemas presidencialistas a Constituição dá liberdade aos presidentes para formar os gabinetes que quiseram, eles podem nomear um Ministério multipartidário que não necessariamente recompense os partidos de acordo com o princípio de proporcionalidade (p. 480). 
A consequência lógica do argumento supracitado é que, em virtude das regras que estruturam a tomada de decisão no presidencialismo, não existem incentivos para que o chefe do Executivo proceda a uma distribuição proporcional de recursos no gabinete. Mais do que isso, mesmo aceitando o fato de que existem incentivos para a formação de coalizões, as regras do sistema presidencialista dotariam o chefe do gabinete de poder para fazer valer apenas as suas vontades pessoais na agenda de políticas do Executivo, em detrimento das preferências dos outros integrantes do governo.

Dentro dessa perspectiva, se não há garantias de que suas preferências políticas sejam consideradas e/ou que recursos sejam compartilhados, por que partidos aceitariam integrar coalizões em regimes presidencialistas? Assumindo a motivação racional dos atores, a única hipótese plausível para a entrada e permanência dos partidos na coalizão de governo é a motivação para ocupar cargos e transformá-los em benefícios eleitorais. Esse argumento é, no entanto, fracamente amparado por análise empírica sistemática. Nenhuma evidência leva a crer que o presidente personaliza a agenda de políticas do gabinete. Em última análise, esse raciocínio se sustenta sob a hipótese de que, exceto o partido do presidente, todos os demais são movidos exclusivamente pelo desejo de ocupar cargos e que estes, por si só, garantem benefícios eleitorais.

Deixando de lado momentaneamente este ponto (a da motivação dos partidos em se juntar a uma coalizão comandada pelo presidente), cabe notar que tal visão acentua demasiadamente o poder pessoal da presidência seja do ponto de vista formal (o que diz a constituição), seja do ponto de vista da estrutura dos incentivos. Dito de forma mais clara, a afirmação de que presidentes podem escolher livremente seus ministros é exagerada. Além disso, mesmo que não fossem limitados formalmente, não segue que não sejam limitados pela contribuição e força dos partidos que integram a coalizão.

Análises empíricas recentes mostram que, do ponto de vista formal e institucional, presidentes estão longe ser atores plenipotenciários (Cheibub; Elkins; Ginsburg, 2014; Elgie, 1997; Vercesi, 2012). Araújo et al (2015), ao analisarem dezoito presidencialismos latino-americanos, mostram que existe grande variação intrassistema no que diz respeito ao grau de dominância do presidente no gabinete. Além de existirem atores com capacidade para vetar formalmente as nomeações e/ou demissões que o chefe de governo propõe, em vários dos países analisados, o presidente 
precisa da anuência dos outros integrantes do gabinete para formular e enviar propostas de políticas ao parlamento.

Utilizo o mesmo indicador anteriormente operacionalizado pelos autores supracitados na análise do grau de dominância do chefe do Executivo em sistemas presidencialistas, para investigar comparativamente o grau de verticalização do gabinete em sistemas parlamentaristas, semi-presidencialistas e presidencialistas. A composição do indicador leva em consideração cinco dimensões do processo formal de tomada de decisão em gabinetes:

1. Demissão de Ministros (Cabinet removal) - diz respeito à capacidade do chefe do Executivo para demitir os integrantes do gabinete a qualquer tempo, sem a anuência de alguma das casas legislativas;

2. Procedimento de seleção para o Gabinete (Cabinets' selection procedures) - diz respeito à prerrogativa exclusiva do chefe do Executivo para nomear os integrantes do gabinete;

3. Condições para a elegibilidade (The restrictions of eligibility to the office of minister) - diz respeito à possibilidade do chefe do Executivo compor o gabinete com os atores de sua preferência, sem que haja alguma regra que limite a sua escolha;

4. Anuência dos Ministros para a tomada de decisão (The minister's countersignature for executive decisions) - diz respeito à necessidade de concordância de outros integrantes de gabinete para que as decisões do gabinete de governo sejam tomadas;

5. Poderes Legislativos dos Ministros (The legislative powers of ministers) - diz respeito à prerrogativa dos ministros para enviar propostas de políticas ao parlamento.

As cinco dimensões foram operacionalizadas de forma dicotômica. Sempre que, numa dada dimensão, as regras do processo decisório favorecem a predominância do chefe do Executivo, foi imputado o valor 1 (um). Nos casos em que as regras não favorecem o chefe do Executivo, foi imputado o valor 0 (zero). O indicador de dominância do chefe do Executivo, denominado grau de verticalização do gabinete, varia entre nenhuma verticalização (0) - em que as regras formais de tomada de decisão no gabinete constrangem totalmente decisões unilaterais do chefe do Executivo (pimus inter pares) - e máxima verticalização (5) - em que as regras formais de tomada de decisão no gabinete habilitam o chefe do Executivo a tomar as decisões unilateralmente (sole executive). 
O gráfico 1.1 apresenta o grau de verticalização do gabinete em cinquenta e cinco (55) democracias, distribuídas entre os sistemas parlamentarista (22), semipresidencialista (14) e presidencialista (19).

Gráfico 1.1. Grau de verticalização do processo de tomada de decisão no gabinete em 55 democracias por sistema de governo ${ }^{5}$.

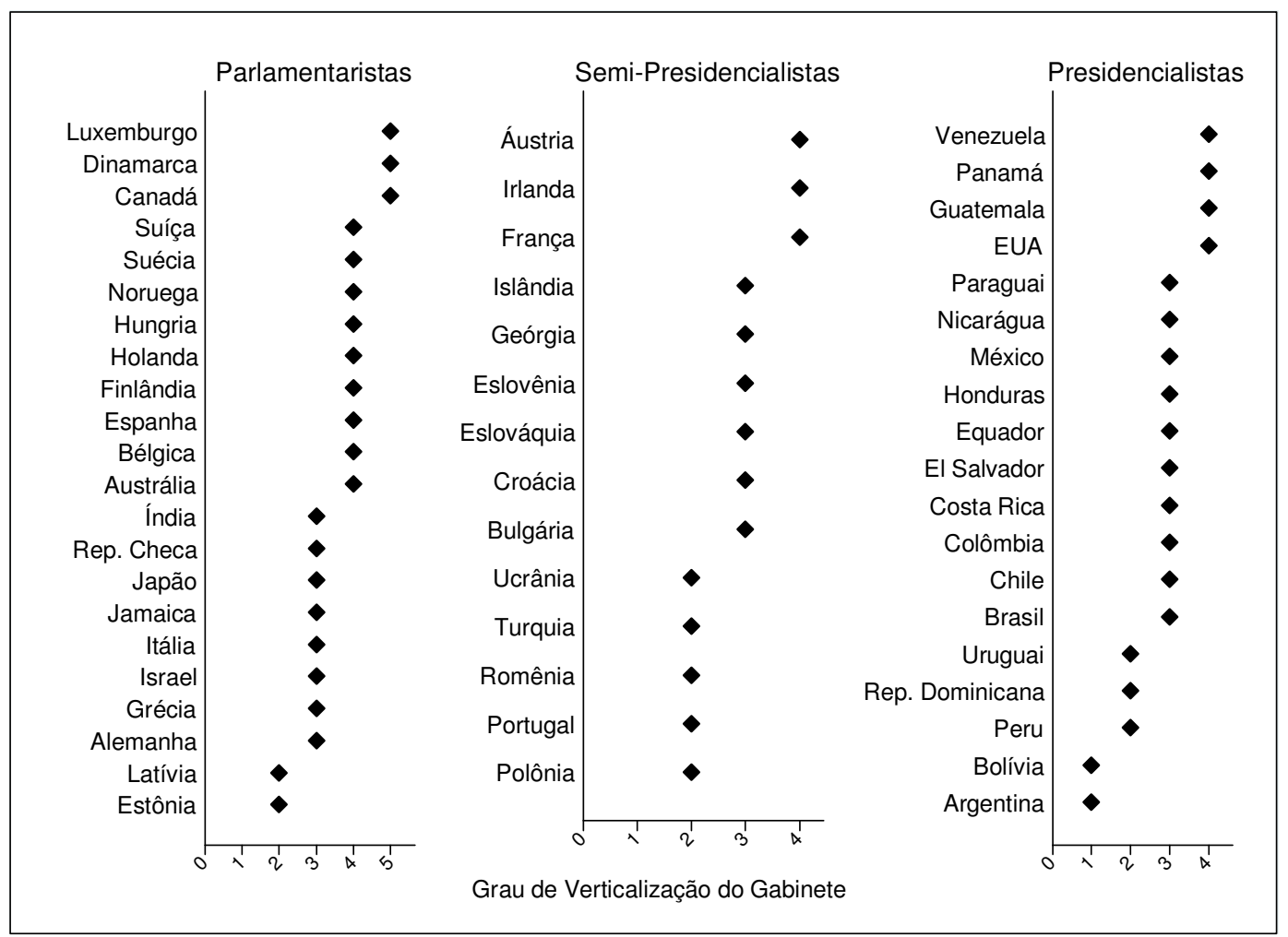

Fonte: Núcleo de Estudos Comparados e Internacionais (NECI/USP).

A primeira constatação empírica é que existe uma substantiva variação intrassistemas e muito menos variação intersistemas do que as formulações dicotômicas baseadas na distinção Linzeana costumam ressaltar. Formalmente, os sistemas semipresidencialista e presidencialista são bastante semelhantes, não havendo nenhum caso de extrema verticalização (5) nos dois sistemas. Na amostra dos casos presidencialistas, os países com maior grau de verticalização são Venezuela, Panamá, Guatemala e EUA,

\footnotetext{
${ }^{5}$ O Enquadramento dos países em cada sistema de governo segue o critério utilizado por Elgie (2007), segundo o qual as democracias semi-presidencialistas são aquelas em que o chefe de Estado (Presidente) é escolhido via sufrágio universal e o chefe de governo (primeiro ministro) é escolhido pelo parlamento, estando, esse último, sujeito à confiança do Legislativo. As democracias presidencialistas são aquelas nas quais, via sufrágio universal, é escolhido um presidente que desempenha, simultaneamente, o papel de chefe de Estado e chefe de governo. As democracias parlamentaristas são definidas pela escolha indireta via Legislativo - de um chefe de governo que depende da confiança dos partidos representados no parlamento.
} 
todos com score (4). Nesse grupo, o Brasil figura numa posição intermediária com score (3). Entre os casos semi-presidencialistas, Áustria, Irlanda e França são os casos onde o chefe do Executivo é mais dominante nas decisões do gabinete. Casos de extrema verticalização são observados apenas nas democracias parlamentaristas, nas quais o chefe do Executivo é hegemônico no processo decisório intragabinete em Luxemburgo, Dinamarca e Canadá.

Como informa o gráfico 1.2, a média de verticalização do gabinete nos países parlamentaristas é consideravelmente maior que nos dois outros sistemas. Isto é, além de haver menos diferença entre os sistemas do que normalmente a literatura costuma pressupor, são as regras dos sistemas parlamentaristas que delegam maior poder ao chefe do Executivo. O teste de diferença entre os sistemas pode ser visualizado na

\section{tabela 1.1}

Gráfico 1.2. Boxplot do grau de verticalização do gabinete por sistema de governo

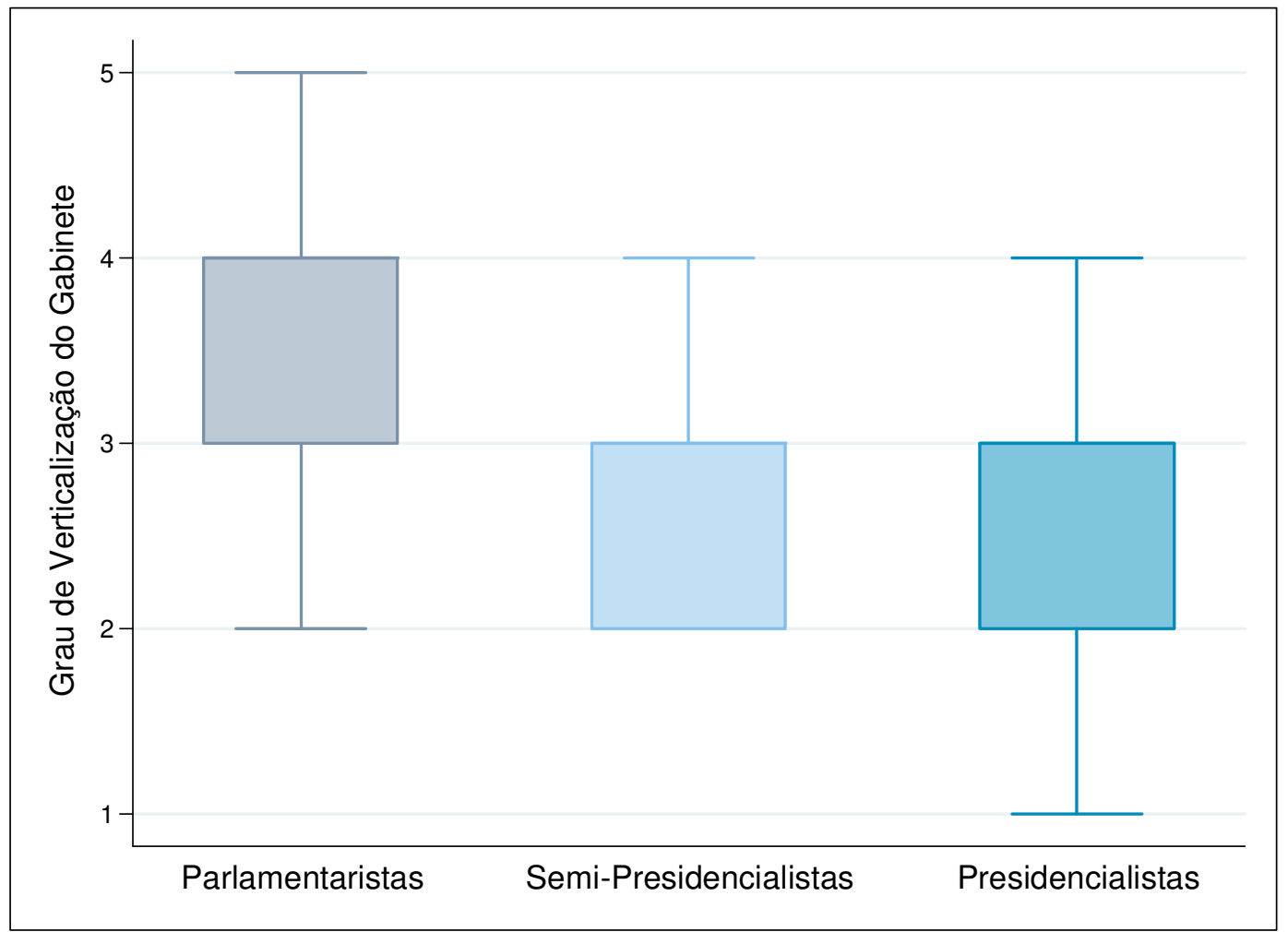

Fonte: Núcleo de Estudos Comparados e Internacionais (NECI/USP).

Não existe diferença estatisticamente significante entre o grau de verticalização observada nos sistemas presidencialistas e nos contextos semi-presidencialistas. A diferença é substantiva e estatisticamente significante apenas quando o grupo dos países parlamentaristas é comparado com os outros dois sistemas de governo. Na média, o 
processo decisório em gabinetes dos países parlamentaristas é mais verticalizado quando comparado aos países que adotam o sistema presidencialista e parlamentarista.

Tabela 1.1. Teste de Tukey (análise de variância) - entre sistemas de governo.

\begin{tabular}{ccccccc}
\hline Categoria & Diferença (média) & SD & T & p value & Inter. Confiança (95\%) \\
\hline Presidencialismo vs Parlamentarismo & -0.0748 & 0.0266 & -2.81 & 0.019 & -0.1390 & -0.0106 \\
Semi-Presidencialismo vs Parlamentarismo & -0.0733 & 0.0290 & -2.53 & 0.038 & -0.1434 & -0.0032 \\
Presidencialismo vs Semi-Presidencialismo & -0.0015 & 0.0299 & -0.05 & 0.999 & -0.0737 & 0.0707 \\
\hline
\end{tabular}

Fonte: elaborado pelo autor a partir dos dados do NECI/USP.

Não é possível, portanto, inferir o grau de compartilhamento de poder no gabinete a partir das regras formais de um dado sistema de governo. Em outras palavras, as distinções institucionais entre presidencialismo e parlamentarismo não levam a estruturas de incentivos diversas no que diz respeito à partilha do poder. Pode até ser verdade que presidentes não "recompensem os partidos de acordo com o princípio de proporcionalidade”, mas essa diferença não pode ser explicada com base no poder pessoal do chefe do executivo.

Embora existam evidências de que nos parlamentarismos europeus os recursos do gabinete para implementação de políticas sejam distribuídos de acordo com o peso legislativo dos partidos (Browne; Franklin, 1973; Budge; Keman, 1993; Schofield; Laver, 1985), essa não é, como sugere parte da literatura, uma decorrência das regras formais do processo decisório em gabinetes e, tampouco, deve ser tomada como necessária. Como mostram Laver \& Schofield (p.168, 1998), há considerável variação na proporcionalidade da distribuição de recursos nos gabinetes parlamentaristas europeus estudados.

Em qualquer sistema de governo, a distribuição de recursos entre parceiros políticos é uma decisão de caráter eminentemente político. Seja qual for o poder formal do chefe do Executivo sobre as decisões do gabinete, a antecipação da reação dos atores partidários no Legislativo informa a distribuição de pastas e recursos, o que não implica a anulação completa do componente arbitrário ou residual deixado nas mãos do chefe do executivo para nomear e demitir os integrantes do gabinete.

Da mesma forma que nos sistemas parlamentaristas, nos presidencialismos, a agenda do Executivo é construída politicamente a partir da antecipação - e consequente processamento - das preferências dos atores que integram os Poderes Executivo e Legislativo (Limongi; Figueiredo, 2009). Ao formar coalizões, presidentes e primeiros 
ministros respondem ao mesmo imperativo, a saber, à necessidade de assegurar maioria no interior do Legislativo. Contudo, como demonstrou Strom (1990a), isso não significa que a maioria legislativa seja obtida unicamente pela distribuição de pastas ministeriais. Isso seria verdade apenas se os atores políticos fossem movidos exclusivamente por cargos, isto é, se fossem, para usar o jargão, office-seeking (Cheibub, 2007, Cheibub; Limongi, 2010). A simples existência de governos minoritários bem sucedidos mostra que tal premissa é falsa. Não apenas os atores políticos se importam com policies como também controlar cargos não é a única forma de obter o que querem. Esse raciocínio tem consequências diretas para a interpretação da taxa de coalescência proposta por Amorim Neto (2000), isto é, uma relação desproporcional entre cadeiras e recursos não é uma evidência de um maior poder pessoal do presidente.

$\mathrm{O}$ argumento desenvolvido tem implicações tanto para as motivações do formador da coalizão quanto para os que a integram, uma vez que os partidos aceitam fazer parte de uma coalizão proposta pelo presidente. Não é demais lembrar que Linz argumentou que presidentes não buscariam formar coalizões ${ }^{6}$, mas se porventura o fizessem, seus apelos encontrariam ouvidos moucos nos partidos de oposição. Por aspirarem à presidência, estes partidos recusariam o convite. Como se vê, o argumento toma por base a premissa office-seeking ${ }^{7}$.

$\mathrm{Na}$ literatura dedicada ao presidencialismo brasileiro, a ênfase tem recaído sobre as motivações presidenciais. O presidente tem incentivos para formar uma coalizão e, por isso, teríamos o que se convencionou chamar de presidencialismo de coalizão. $\mathrm{O}$ presidente teria razões para partilhar o poder, mas o que de fato o chefe do Executivo partilha? Qual o objetivo ou o que quer um partido quando passa a apoiar o Executivo? Em boa parte dessa literatura, implicitamente, se assume que tudo que os partidos querem são os cargos, as pastas ministeriais. Partidos trocariam votos para aprovar a agenda do presidente pelo controle de pastas. Essa seria a essência do presidencialismo de coalizão.

\footnotetext{
${ }^{6} \mathrm{O}$ argumento de que no sistema presidencialista não existiriam incentivos para a cooperação entre os dois Poderes defendida por Linz (1990) foi também sustentada por Shugart \& Carey (1992), Mainwaring (1993), Stepan \& Skach (1993) e Mainwaring \& Shugart (1997). Para uma análise crítica dessa corrente da literatura ver Power \& Gasiorowski (1997) e Cheibub \& Limongi (2002). Para um balanço das análises sobre os efeitos da variável "sistema de governo" sobre o processo de tomada de decisão em democracias ver Elgie (2005) e Chaisty, Cheesman \& Power (2014).

7 Conceito que define o modelo de atuação partidária no qual os atores (políticos) desejam, prioritariamente, maximizar seu controle sobre cargos na estrutura estatal. Assumindo que vencer eleições é o maior dos objetivos partidários, ocupar o Executivo é a melhor das estratégias para acessar benefícios que lhes garantam a permanência no poder (Riker, 1962).
} 
Nesse tipo de argumento, os partidos integrados à coalizão só se interessariam por cargos e, portanto, seu apoio estaria condicionado à proporcionalidade entre sua contribuição em votos a recursos ou pastas. Onde e quando esta proporcionalidade não for obtida, o apoio ao presidente declina, isto é, a disciplina legislativa dos partidos da coalizão cai quando aumenta o grau de desproporcionalidade na distribuição de cargos (Amorim Neto, 2000; Melo; Pereira, 2013; Raile; Pereira; Power, 2011). Uma versão levemente modificada desse argumento se ampara no modelo de tomada de decisão em gabinetes proposto por Laver \& Shepsle (1994), segundo o qual cada ministro implementa "sua agenda" de políticas de forma independente e autônoma aos demais. A tradução desse modelo ao Brasil ganha corpo na noção de que ministérios seriam administrados com "porteiras fechadas", ou seja, que a delegação ao ministro seria absoluta, permitindo que o beneficiário venha a extrair o máximo de benefícios eleitorais possíveis do ministério recebido.

O objetivo central deste trabalho é questionar esse tipo de visão. Partidos que integram as coalizões organizadas pelo presidente não são movidos exclusivamente por cargos. Como argumentaram tempos atrás Laver e Schofield (1998), premissas exclusivamente office-seeking são inconsistentes do ponto de vista lógico. Quem ocupa um cargo não pode derivar utilidade do ato em si. Sobretudo porque, em si mesmo, ocupar cargos não rende votos. Para que o cargo garanta a reeleição é preciso desenhar e implementar políticas, ainda que elas se resumam à pura patronagem ou ao clientelismo. Assim, mesmo no modelo da "porteira fechada", quem recebe um ministério deveria ser capaz de formular políticas.

Portanto, neste trabalho, seguindo as proposições contidas em contribuições recentes (Alemán; Tsebelis, 2011; Araújo, Freitas; Vieira, 2015; Magar; Moraes, 2012; Zucco, 2013) parto do suposto de que partidos integram coalizões no presidencialismo com o intuito de influenciar a agenda política do Executivo, uma agenda que é, de uma forma ou de outra, formada coletivamente por atores que têm, ao mesmo tempo, interesses convergentes e concorrentes. Por isso mesmo, a execução dessa agenda envolve o constante monitoramento por parte dos parceiros de gabinete.

Da mesma forma que nos parlamentarismos multipartidários europeus, os partidos representados no gabinete reagem à estratégia de distribuição de recursos adotada pelo chefe do gabinete. Ao contrário do que prescrevem as abordagens convencionais sobre o caso brasileiro, assumo que os partidos não estão preocupados apenas com uma distribuição mais ou menos proporcional de cargos na estrutura do 
Executivo. Parto da premissa de que esses atores se movimentam no sentido de influenciar as políticas do governo. Em outros termos, a ação dos partidos não se dá apenas de forma reativa - não aprovando as propostas oriundas do Executivo no parlamento quando não recebem cargos -, mas também de maneira proativa, buscando agregar suas preferências na agenda de políticas do governo.

As evidências empíricas apresentadas nos próximos capítulos deste trabalho visam mostrar que os partidos políticos que participam da coalizão de governo adotam estratégias para diminuir a assimetria de informação (Asymmetric Information) decorrente da distribuição de recursos para policy em governos multipartidários. Os partidos tentam compensar o déficit de informação a respeito das políticas que lhes interessam, mas que não estão sob seu controle direto através do controle da implementação das políticas públicas. A influência sobre as políticas públicas não depende exclusivamente do peso legislativo do partido transformado em pastas no gabinete. Há outras formas de influenciar e ser ouvido na formulação de políticas no interior do parlamento.

Como mostra Freitas (2013), o tamanho da bancada importa no que diz respeito à capacidade dos partidos para promover alterações nas propostas de políticas. Consequentemente, os partidos que contribuem com mais cadeiras para a coalizão são também aqueles com maior capacidade de agregar suas preferências às propostas de políticas do Executivo discutidas no parlamento. Nos governos FHC e LULA, por exemplo, o partido do presidente (partido formador) e o seu principal partido parceiro no gabinete foram os partidos que mais realizaram alterações nas propostas de Leis debatidas no Congresso Nacional ${ }^{8}$.

Mas essa é apenas uma das facetas pelas quais os partidos podem influenciar as políticas no interior do Legislativo. Faz-se necessário observar também os conflitos existentes na fase de implementação das políticas públicas, onde os ganhos obtidos pelos partidos torna ótima a estratégia de aderir à coalizão de governo. Como argumentarei nos capítulos subsequentes, a análise de todas as arenas que envolvem a execução de políticas permite dimensionar o que ganham os partidos que assumem o custo de integrar coalizões governativas .

O controle de implementação de políticas públicas é o mecanismo mais efetivo de que os partidos dispõem para acessar informações sobre as políticas do Executivo.

\footnotetext{
${ }^{8}$ Ver gráfico 12, p.120 (Freitas, 2013).
} 
Nessa fase, é dada aos partidos a oportunidade de monitorar as áreas de políticas que foram entregues para outros partidos membros do gabinete. Assim, além de poder corrigir parte da assimetria de informação gerada pela delegação em gabinetes multipartidários, os partidos da coalizão podem tentar agregar suas preferências às áreas de policies importantes para os seus objetivos programáticos, mas que lhes foram negadas pelo partido formador do gabinete. Embora os pesos relativos dos partidos se mantenham, na fase de implementação das políticas, todos os partidos da coalizão possuem igual capacidade para monitorar as ações dos seus parceiros de governo. Isso porque, no caso brasileiro, os instrumentos garantidos constitucionalmente ao Poder Legislativo para controlar as ações do Poder Executivo tornam o custo de execução dessa tarefa extremamente reduzido.

Em suma, independente das regras formais de tomada decisão no gabinete, a distribuição de recursos para policy em arranjos multipartidários suscita conflitos entre os integrantes do governo. Esses conflitos, refletidos e processados no Legislativo, são desencadeados pela assimetria de informação inerente ao processo de distribuição de recursos entre os integrantes do gabinete. Da mesma forma que o objetivo dos partidos de influenciar a agenda de políticas do Executivo explica a adesão dos partidos à coalizão de governo, o distanciamento desses atores das políticas que lhes interessa explica as estratégias para obtenção de informação. Como irei argumentar nos próximos capítulos, a diminuição da assimetria de informação é uma condição sine qua non para que os partidos do gabinete possam expressar suas preferências e tentar influenciar as políticas implementadas pelo Executivo. 


\section{CAPÍTULO 2}

\section{Delegação em governos com múltiplas preferências: gabinetes multipartidários no presidencialismo brasileiro}

A teoria da delegação muito tem contribuído para a formulação de modelos capazes de explicar as relações de agência nas arenas de decisão do Estado. As implicações básicas dessa teoria nos fornecem elementos para pensar por que é razoável supor que os partidos presentes no governo monitoram as ações uns dos outros. A existência do controle entre os atores que ocupam o governo é a constatação empírica necessária que permite negar o axioma ${ }^{9}$ apresentado por Axelrod (1970), segundo o qual coalizões de partidos com preferências altamente dispersas no espaço tendem a não sobreviver.

Um ato de delegação nada mais é do que a transferência consentida de uma tarefa a um terceiro. Nos termos de Lupia (2003), a delegação pode ser definida como "um ato onde pessoas ou grupos, chamados de principal, depende de outra pessoa ou grupo, chamados de agente, para perseguir seus interesses" (p. 34).

A delegação possui duas implicações básicas: a possibilidade de conflito de interesses dos participantes envolvidos na relação e a inevitabilidade da assimetria de informação. As duas implicações são decorrentes do pressuposto básico da delegação, a saber, os atores se baseiam em preferências e expectativas diferentes. $\mathrm{O}$ fato dos atores que participam da delegação terem funções de utilidade distintas cria um cenário onde os seus interesses dificilmente estão perfeitamente alinhados.

Se três atores A, B e C recebem do partido formador do gabinete (o chefe da cadeia de delegação) três ministérios $\mathrm{Z}, \mathrm{W}$ e $\mathrm{Y}$, assumindo que cada um desses atores possui um ponto ideal de preferência que determina a sua função de utilidade, e que cada ator possui déficit de informação (Asymmetric Information) em relação à condução das políticas nos ministérios de seus parceiros de governo, é provável que haja conflito de interesses entre a agenda de políticas do Executivo e as ações implementadas por cada um desses atores.

\footnotetext{
${ }^{9}$ A partir do modelo de Minimal Connected Winning Coalitons, Axerold (1970) argumenta que, quando as coalizões de governo são formadas por partidos ideologicamente próximos, os custos de manutenção do acordo político entre os ocupantes do gabinete tendem a ser menores. Ainda de acordo com esse autor, os parâmetros desse modelo permitem derivar os resultados do cenário contrário. Nas circunstâncias em que as coalizões de governo são constituídas a partir de preferências dispersas - grande heterogeneidade ideológica -, os custos de coordenação tornam-se extremamente altos, aumentando a probabilidade da quebra do acordo político selado entre os participantes do governo.
} 
A dinâmica da delegação em gabinetes multipartidários produz uma cadeia ainda mais complexa de relações. Em primeiro lugar, o espaço de ação dos atores é constituído por múltiplos principals e agentes (Muller; Bergman; Strom, 2008). O partido formador do gabinete é o principal dos seus parceiros de gabinete, enquanto a burocracia ministerial é agente dos partidos que controlam as áreas de política do Executivo. Isso significa que nas relações do gabinete todos os partidos ocupam o papel de principal em algum elo da cadeia de delegação (Andeweg, 2000).

Em contextos onde apenas um partido ocupa o governo (contextos com gabinetes unipartidários), a missão do chefe da cadeia de delegação é alinhar as preferências dos seus companheiros de partido com a agenda de políticas do gabinete. Assumindo que os partidos atuam no governo enquanto atores unitários (Laver; Schofield, 1998), a expectativa de assimetria de informação nesse tipo de governo será sempre menor. No caso dos governos multipartidários, a existência de múltiplos principals e agentes aliada à heterogeneidade de preferências observadas, é a razão pela qual o déficit de informação em relação às ações praticadas pelos parceiros de governo é a regra, e não uma contingência como nos governos unipartidários (Epstein; O'halloran, 1999; Laver, 2008; Strom; Müller, 2010).

A questão da assimetria de informação, porém, ganha abrangência apenas se assumimos que os partidos possuem motivação para implementar políticas. Se os partidos desejam apenas ocupar cargos na estrutura do governo, a assimetria de informação é uma questão apenas para o chefe do gabinete que delega áreas de policy para outros atores.

Nos modelos formais utilizados para explicar a tomada de decisão em governos parlamentaristas, a agenda do gabinete é composta de maneira colegial ${ }^{10}$, o que significa que todos os ministros têm a oportunidade de externar suas preferências sobre as políticas do governo antes que estas sejam levadas a cabo. No entanto, esse modelo só pode ser considerado razoável se assumirmos a premissa irreal de que o gabinete decide sobre um número limitado de assuntos (Andeweg, 1985; Mackintosh, 1969).

Além disso, esse modelo parte do pressuposto de que o gabinete é o único ator que decide sobre políticas públicas. Evidências recentes mostram que, embora não exista separação formal entre a agenda do Executivo e a agenda do parlamento que sustenta politicamente o Primeiro Ministro, mesmo no modelo Westminster britânico, as

${ }^{10}$ Em seu uso original o modelo foi batizado de Cabinet government 
propostas de políticas que saem do gabinete são frequentemente alteradas pelos partidos no parlamento (Russell; Gover; Wollter, 2015).

É possível pensar também numa situação oposta ao que postula o modelo colegial. No modelo formulado por Laver \& Shepsle (1994), a repartição de competências é uma exigência dos partidos que aceitam integrar o governo. Os partidos do gabinete recebem cargos e, em troca, concedem apoio político às políticas do chefe do Executivo. Levado ao extremo, nesse modelo não existe espaço para decisões colegiadas nem interesse dos partidos em supervisionar as áreas ministeriais dos partidos parceiros no gabinete. $\mathrm{O}$ chefe do Executivo delega ministérios para terceiros que os gerencia apenas de acordo com as suas próprias preferências. Dentro dessa perspectiva, as políticas implementadas pelos partidos da coalizão não são consideradas pelos outros integrantes do gabinete, uma vez que estes atores estão preocupados apenas em controlar cargos que possam maximizar suas chances de sucesso eleitoral.

Esse modelo tem sido recorrentemente utilizado para analisar contextos presidencialistas. Dado que o presidente não depende da confiança dos integrantes do parlamento, o cálculo do chefe do Executivo para formar coalizões é baseado essencialmente na expectativa de garantir apoio legislativo para as políticas do governo. Assim, o pacto que envolve a formação da coalizão seria baseado na estratégia dos partidos de usufruir dos recursos existentes na máquina pública e transformá-los em retornos eleitorais. No entanto, ainda que os partidos possam pretender participar do governo com a finalidade de aumentar as chances de sucesso eleitoral (Downs, 1957; Riker, 1962), o uso de cargos e recursos monetários se converte em capital político apenas por meio da formulação e execução de políticas públicas (Cheibub; Przeworski; Saiegh, 2004; Cheibub; Limongi, 2002; Laver; Schofield, 1998; Strom, 1990a).

As análises empíricas dos contextos parlamentaristas (Martin; Vanberg, 2005; Moury, 2013; Strom, 1990b) e dos casos presidencialistas (Alemán; Tsebelis, 2011; Araújo; Freitas; Vieira, 2015; Magar; Moraes, 2012) sugerem que o principal incentivo para que os partidos ocupem o gabinete de governo é a possibilidade de agregar suas preferências à agenda de políticas do Executivo. Assim, os problemas de coordenação no interior do gabinete são decorrentes da não concretização dessa expectativa dos partidos de influenciar as políticas do governo. Isso nos obriga, no limite, a utilizar um modelo de compartilhamento de competências no gabinete em que a assimetria de informação seja uma questão para todos os partidos que integram o governo. 
Isso não significa assumir que todos os partidos que ocupam o gabinete tenham uma agenda de políticas bem definida nem que as consequências dessas políticas sejam sempre positivas, mas que a expectativa de convergência é firmada num pacto político de transferências de recursos para a execução de políticas (Luebbert, 1986; Strom, 1990b). É dizer que, para além do oferecimento de cargos e uma parcela do orçamento federal, esse pacto envolve o compartilhamento da agenda de políticas do Executivo (Laver; Schofield, 1998; Strom; Müller, 1999).

Em função dos acordos que o chefe de governo precisa estabelecer para conseguir apoio político, faz-se necessário transferir para outros partidos a competência sobre uma vasta lista de políticas caras à agenda do Executivo. Apesar disso, o partido formador e os outros partidos que integram o gabinete não são indiferentes às políticas conduzidas pelos seus parceiros de governo, fazendo uso de mecanismos de monitoramento para influenciar as políticas executadas pelos parceiros da coalizão. Esses mecanismos, por sua vez, além de informar os partidos sobre as consequências das ações executadas pelos seus parceiros, viabiliza a continuidade do pacto político em governos multipartidários, mesmo quando os gabinetes são permeados por heterogeneidade e preferências extremas (Thies, 2001).

As evidências que validam o argumento de que os conflitos do gabinete são processados no parlamento (Browne; Dreijmanis, 1982; Martin; Vanberg, 2008, 2011; Pridham, 1986; Schofield, 1997), são as mesmas que permitem concluir que esses problemas de coordenação de preferências nem sempre levam ao esfacelamento do acordo político entre Executivo e Legislativo. O monitoramento mútuo entre os atores do gabinete impede que os partidos se sintam completamente alijados das áreas de políticas que o chefe de governo delega para outros partidos.

No caso brasileiro, embora a crescente fragmentação do sistema partidário induza a formação de gabinetes grandes e heterogêneos (Kinzo, 2006; MartínezGallardo, 2010; Palermo, 2000; Pereira; Mueller, 2003; Santos, 1997), os resultados observados da relação Executivo-Legislativo são indicativos de que os parceiros da coalizão dão suporte à aprovação das propostas de políticas públicas do Executivo (Figueiredo; Limongi, 1995,1999, 2000).

Esse argumento possui duas principais implicações. Em primeiro lugar, as taxas de sucesso do Executivo não podem ser lidas como monopólio do partido formador do gabinete - o partido do presidente - sobre as propostas de políticas do governo, mas como capacidade do presidente de coordenar e filtrar as propostas oriundas dos 
ministérios gerenciados pelos parceiros da coalizão. A segunda implicação é decorrente da primeira. Ainda que a análise da gestão dos gabinetes no Brasil revele que o partido formador possui maior capacidade de agregar suas preferências às políticas formuladas no interior do Executivo (Batista, 2013; Lameirão, 2015), existem evidências das redes de cooperação que se formam entre os membros do gabinete para elaborar projetos em coautoria e integrar suas preferências ao portfólio de políticas do governo (Rennó; Wojcik, 2015).

Dessa maneira, os partidos têm a oportunidade de influenciar o resultado das políticas públicas tanto na fase de proposição das políticas no interior do gabinete, quanto no transcurso da atividade legiferante do Poder Legislativo (Freitas, 2013; Inácio; Rezende, 2015). Entretanto, embora em sua fase de elaboração a agenda do Executivo seja compartilhada entre os parceiros do gabinete, o grau de participação de cada partido nos acordos do gabinete é, com alguma margem de imprecisão, função da força legislativa desses atores. Em outros termos, os maiores partidos são os atores com maior proeminência nas redes de formulação intragabinete (Gaylord; Rennó, 2015).

Nesse cenário, se as oportunidades para agregar preferências sobre políticas fossem circunscritas à fase da formulação de políticas, os partidos que contribuem com menos cadeiras para a coalizão legislativa estariam, necessariamente, em posição de desvantagem no que diz respeito à capacidade de influenciar as políticas formuladas pelo Executivo. O controle mútuo entre os parceiros da coalizão na fase da implementação das políticas públicas permite que todos os partidos do gabinete tenham, mesmo passado o processo de formulação das políticas, a chance de influenciar os resultados das ações executadas por outros partidos do gabinete.

A tabela 2.1 descreve as principais características dos governos multipartidários formados no Brasil entre 1995 e 2014, o grau de partidarismo e o grau de heterogeneidade de cada um dos 15 gabinetes analisados. A taxa de partidarismo considera a proporção de ministros com apoio partidário no Legislativo. Gabinetes com baixas taxas de partidarismo são, na maior parte dos $\operatorname{casos}^{11}$, menos heterogêneos, em virtude do número reduzido de atores partidários que ocupam o governo. Nesse sentido, os dois indicadores são complementares, uma vez que o cálculo da heterogeneidade permite dimensionar o grau de dispersão das preferências partidárias.

\footnotetext{
${ }^{11}$ Apesar de a ocorrência ser improvável na prática, coalizões pequenas podem apresentar alto grau de heterogeneidade. Um partido formador de centro pode compor uma coalizão com um partido de extrema esquerda e outro partido de extrema direita, por exemplo.
} 
Imagine uma situação hipotética na qual dois gabinetes A e B congregam 10 ministros e 9 são suportados por algum partido no Legislativo. Em ambos, a taxa de partidarismo será de $90 \%$, no entanto, no gabinete A, 8 dos 10 ministros pertencem ao partido do presidente enquanto, no gabinete $\mathrm{B}$, os ministros pertencem a 5 partidos diferentes. Nesse caso, observaríamos um baixo grau de heterogeneidade de preferências no gabinete A e um grau de dispersão de preferências consideravelmente maior no gabinete B. A utilização concomitante dos dois indicadores se justifica, portanto, pela necessidade de julgar se, nos casos em que se observa um baixo grau de heterogeneidade, os gabinetes são compostos por poucos ministros partidários de um mesmo partido ou se existe um grande número de ministros sem filiação partidária.

O grau de heterogeneidade do gabinete ${ }^{12}$ foi calculado a partir dos scores utilizados por Power e Zucco (2009) e Zucco e Lauderdale (2011), tendo como referência o posicionamento ideológico dos partidos representados no Congresso brasileiro. O nível de dispersão das preferências do gabinete é o resultado da soma das diferenças entre o posicionamento ideológico do partido formador e o posicionamento ideológico dos outros partidos que compõem um dado gabinete, ponderado pelo número de partidos integrantes, ou seja, trata-se da distância média dos partidos em relação ao partido formador, corrigida pelo número de vezes que esta operação é realizada.

Os gabinetes formados durante os dois mandatos do presidente Fernando Henrique Cardoso (FHC), do PSDB, foram compostos por um número médio de 4 partidos. As características distintivas desse período é a proximidade relativa das preferências dos partidos que integram o governo e a baixa média da taxa de partidarismo - 0,62. Os gabinetes do governo FHC apresentam um padrão menos heterogêneo - média de 0,57 - quando comparados aos gabinetes formados nos mandatos do presidente Luís Inácio da Silva (LULA) e da presidenta Dilma Rousseff (DILMA), ambos do Partido dos Trabalhadores (PT). O padrão é explicado pelo elevado número de ministros com perfil técnico ${ }^{13}$ nomeados naquele período.

Nenhum dos três presidentes analisados - FHC, LULA e DILMA - foi capaz de construir uma rede de apoio político com partidos próximos no espectro ideológico. Todavia, a dispersão de preferências observada nos governos petistas é consideravelmente maior. A média de heterogeneidade dos gabinetes de 0,76 e 0,67,

\footnotetext{
12 A operacionalização do cálculo pode ser visualizada no apêndice A deste capítulo.

${ }^{13}$ Ministros técnicos foram considerados como sendo da cota do Presidente. Isto é, assumo que esses ministros possuem as mesmas preferências do partido formador do gabinete.
} 
respectivamente, é resultante da formação de governos grandes - média de 7,3 partidos nos mandatos dos presidentes LULA e DILMA - e com preferências dispersas. Esses elevados scores de heterogeneidade são decorrentes das altas taxas de partidarismo registradas nos governos dos dois presidentes do PT.

Tabela 2.1. Características dos gabinetes formados no Brasil (1995 -2014).

\begin{tabular}{ccccc}
\hline $\begin{array}{c}\text { Identificação } \\
\text { do }\end{array}$ & Partidos integrantes do Gabinete & $\begin{array}{c}\text { \% de Cadeiras } \\
\text { da Coalizão na } \\
\text { CDabinete }^{14}\end{array}$ & $\begin{array}{c}\text { Taxa de } \\
\text { Partidarismo } \\
\text { do Gabinete }^{\mathbf{1}}\end{array}$ & $\begin{array}{c}\text { Heterogeneidade } \\
\text { Ideológica do } \\
\text { Gabinete }\end{array}$ \\
\hline FHC I 1 & PSDB - PFL - PMDB - PTB & 0,56 & 0,58 & 0,73 \\
FHC I 2 & PSDB - PFL - PMDB - PTB - PPB & 0,77 & 0,75 & 0,78 \\
FHC II 1 & PSDB - PFL - PMDB - PPB & 0,68 & 0,78 & 0,50 \\
FHC II 2 & PSDB - PMDB - PPB & 0,45 & 0,39 & 0,25 \\
Lula I 1 & PT - PL - PCdoB - PSB - PTB - PDT - PPS - PV & 0,43 & 0,83 & 0,74 \\
Lula I 2 & PT - PL - PCdoB - PSB - PTB - PPS - PV - PMDB & 0,62 & 0,83 & 0,91 \\
Lula I 3 & PT - PL - PCdoB - PSB - PTB - PV - PMDB & 0,58 & 0,87 & 0,60 \\
Lula I 4 & PT - PL - PCdoB - PSB - PTB - PMDB & 0,58 & 0,83 & 0,64 \\
Lula I 5 & PT - PL - PCdoB - PSB - PTB - PMDB - PP & 0,70 & 0,78 & 0,79 \\
Lula II 1 & PT - PR - PCdoB - PSB - PTB - PMDB - PP - PRB & 0,61 & 0,74 & 0,85 \\
Lula II 2 & PT - PR - PCdoB - PSB - PTB - PMDB - PP - PDT - PRB & 0,68 & 0,83 & 0,85 \\
Lula II 3 & PT - PR - PCdoB - PSB - PMDB - PP - PDT - PRB & 0,63 & 0,83 & 0,67 \\
Dilma 1 & PT - PR - PCdoB - PSB - PMDB - PDT - PP & 0,64 & 0,88 & 0,60 \\
Dilma 2 & PT - PR - PCdoB - PSB - PMDB - PDT - PP- PRB & 0,61 & 0,79 & 0,65 \\
Dilma 3 & PT - PR - PCdoB - PMDB - PDT - PP- PRB & 0,56 & 0,79 & 0,77 \\
\hline
\end{tabular}

Fonte: CEBRAP e Núcleo de Estudos Comparados e Internacionais (NECI/USP). ${ }^{1}$ Proporção de ministros com apoio partidário no Legislativo.

A maior dispersão das preferências dos partidos no governo implica custos de coordenação desses atores e torna mais difícil o estabelecimento de processos de cooperação no gabinete (Huber, 1998). Mais do que isso, agrava o problema da assimetria de informação inerente à delegação (Epstein; O'halloran, 1999), criando fortes incentivos para o monitoramento ex post dos parceiros da coalizão (Müller; Strom, 2003; Strom; Müller, 2010).

O objetivo do próximo capítulo é mostrar de que forma a composição de gabinetes mais heterogêneos está relacionada com a maior incidência de controle mútuo entre os partidos parceiros da coalizão. Utilizando as prerrogativas de controle

\footnotetext{
${ }^{14} \mathrm{O}$ critério utilizado neste capítulo para registrar o início e o fim de cada coalizão foi proposto por Müller \& Strom (2003) para classificar gabinetes parlamentaristas na Europa e, posteriormente, adotado por Figueiredo (2007) para classificar os gabinetes multipartidários no Brasil. Um novo gabinete é formado sempre que (A) algum partido entra ou sai do gabinete; (B) ocorrem eleições presidenciais ou; (C) ocorre uma dissolução prematura do governo - um impeachment ou morte do Presidente, por exemplo.

${ }^{15}$ Câmara dos Deputados.
} 
horizontal do Poder Legislativo, os partidos mitigam os problemas da delegação por meio do monitoramento das políticas públicas implementadas pelo Executivo. 


\section{CAPÍTULO 3}

\section{Hipóteses, dados e métodos}

\subsection{Hipóteses}

A principal hipótese deste trabalho é a de que a probabilidade de controle das ações de implementação dos partidos parceiros de governo será maior em gabinetes mais heterogêneos - isto é, a incidência de controle horizontal será maior em governos compostos por preferências mais heterogêneas [H1]. Isso porque, à medida que aumenta a distância entre as preferências ideológicas dos partidos que compõem a coalizão de governo, crescem os incentivos para o monitoramento das ações de implementação de políticas públicas dos parceiros de governo. Duas outras hipóteses podem ser derivadas a partir desta primeira.

Em primeiro lugar, o que explica a posição de centralidade dos atores nas redes de controle intragabinete é a quantidade de recursos para policy que estes atores dispõem [H2]. Dessa forma, espero que o partido formador e os seus principais parceiros de gabinete recebam maior volume de controle. Em segundo lugar, se o mecanismo que explica a formação das redes é a motivação dos partidos da coalizão para agregar suas preferências às políticas, espero que as ações de controle dos partidos representados no gabinete se concentrem nas áreas ministeriais com mais recursos (mais salientes) para a implementação de políticas públicas [H3].

\subsection{Controle horizontal de políticas públicas via requerimento de informação} (RIC)

Na mesma linha dos trabalhos de Sartori (1994), O'Donnell (1998), e Lemos \& Power (2013), utilizo o termo controle horizontal neste trabalho para me referir às prerrogativas constitucionalmente delegadas ao Poder Legislativo para monitorar solicitando informações e cobrando providências acerca da implementação de políticas públicas - as ações do Poder Executivo.

O requerimento de informação (RIC) é um dispositivo de controle horizontal à disposição dos parlamentares brasileiros. Qualquer Deputado ${ }^{16}$ em exercício pode protocolar junto à Mesa Diretora da Câmara dos Deputados pedido de investigação das ações de algum ministério e/ou órgão do Executivo. Inserido no rol das medidas de

\footnotetext{
${ }^{16}$ Os Senadores também podem apresentar requerimentos de informação, mas não serão analisados neste trabalho.
} 
accountability do Poder Legislativo, trata-se de um mecanismo formal e de baixo custo para o controle das ações implementadas pelo Executivo. Por meio do requerimento de informação, os parlamentares são capazes de exercer efetivo controle sobre as ações da burocracia ministerial. Qualquer ato, ação ou programa relacionado à implementação de políticas públicas pode ser alvo de controle dos parlamentares. Os órgãos notificados devem apresentar as devidas explicações sob a pena de crime de responsabilidade. Como prescreve o artigo 116 do regimento interno da Câmara dos Deputados,

"Os pedidos escritos de informação a Ministro de Estado, importando crime de responsabilidade a recusa ou o não atendimento no prazo de trinta dias, bem como a prestação de informações falsas, serão encaminhados pelo PrimeiroSecretário da Câmara, observadas as seguintes regras" (pag.98).

Ainda, de acordo com a Questão de Ordem ${ }^{17}$ 469/2004, "nos casos de recusa ou não atendimento no prazo de 30 dias, referente a requerimento de informação a Ministro de Estado, comunica-se que tem sido procedimento da Casa deixar que o Deputado requerente da informação decida na qualidade de cidadão brasileiro, sobre a conveniência ou não de processar ministro de estado por crime de responsabilidade, perante o Supremo Tribunal Federal, uma vez que tem plena legitimidade para fazê-lo".

Como destaca Lemos (2005), tal instrumento legislativo, a despeito de seu baixo custo para a apresentação ${ }^{18}$, é um mecanismo formal e efetivo para a correção de assimetrias informacionais e controle das atividades dos órgãos do Poder Executivo. O requerimento de informação é uma eficiente ferramenta para forçar os ministros a revelar informações que de outra forma não seriam reveladas, criando constrangimentos e elevando os custos de ação destes atores. Trata-se, portanto, de um meio suficientemente adequado para o monitoramento dos parceiros do gabinete.

No gráfico 3.1, pode ser visualizada a tendência do uso de requerimentos de informação pelos partidos da coalizão, para controlar as ações da burocracia ministerial dos seus parceiros de gabinete. Foram consideradas todas as 22.688 ações de controle

\footnotetext{
${ }^{17}$ As questões de ordem são utilizadas pelos parlamentares para suscitar, em qualquer momento da sessão, dúvida a respeito de interpretação ou aplicação do regimento em caso concreto, relacionada com a matéria tratada na ocasião.

${ }^{18} \mathrm{O}$ requerimento de informação deve ser elaborado por escrito e apresentado no plenário de qualquer uma das Casas (Câmara dos Deputados ou Senado), onde será lido, submetido à votação e aprovado por maioria simples.
} 
apresentadas pelos parlamentares da Câmara dos Deputados entre 1995 e 2014. A linha vermelha é a variação da proporção de requerimentos de informação apresentados pelos partidos da coalizão, denominada "Taxa de Controle Horizontal no Gabinete" e representado no eixo (Y1). Os traços de cor verde representam os gabinetes de governo formados no Brasil no mesmo período. A extensão desses traços representa o grau de dispersão ideológica, indicador do grau de heterogeneidade de preferências em cada gabinete $^{19}(\mathrm{Y} 2)$.

Gráfico 3.1. Variação do número de requerimentos de informação em função do grau de heterogeneidade ideológica do gabinete de governo (1995-2014).

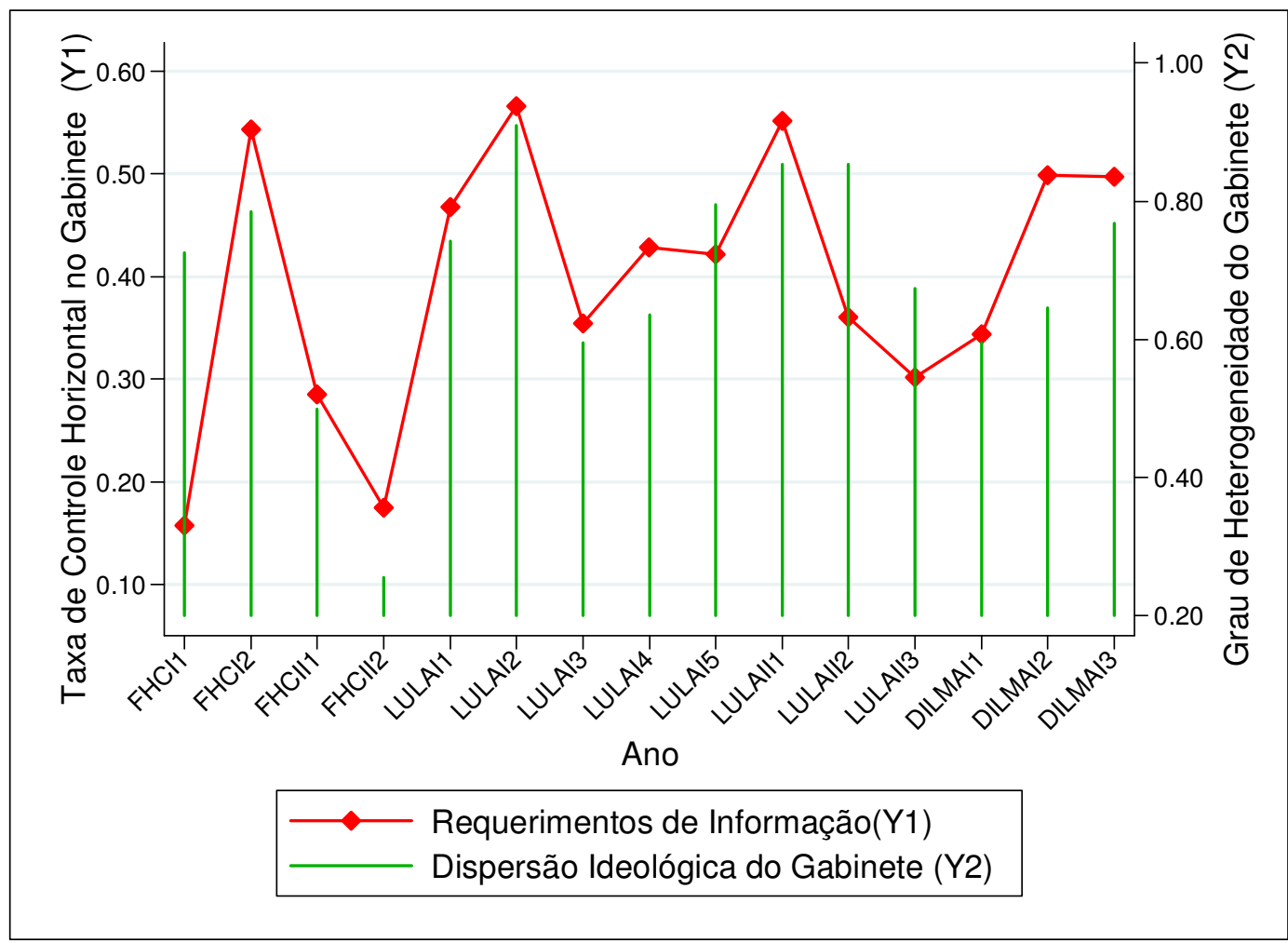

Fonte: Elaborado pelo autor a partir dos dados da Câmara dos Deputados

A análise no tempo dos eixos (Y1) e (Y2) evidencia a forte correlação entre a taxa de controle da burocracia ministerial e o grau de heterogeneidade dos gabinetes. Medido pelo coeficiente de Pearson, as duas linhas apresentam correlação de $0.81^{20}$ numa escala que varia entre 0 e 1 . Isso indica que os partidos da coalizão intensificam o

\footnotetext{
${ }^{19}$ Assim como na tabela 2.1, a heterogeneidade ideológica dos gabinetes foi calculada a partir dos dados presentes em Power \& Zucco (2009); Zucco \& Lauderdale (2011).

${ }^{20}$ No nível de $\mathrm{p}<0.01$.
} 
controle sobre a burocracia ministerial dos seus parceiros de governo, quando o gabinete é composto por preferências mais dispersas e/ou extremas.

Entre 1996 e 2002, verifica-se uma tendência de queda no controle da burocracia ministerial, fato que está relacionado com a formação de gabinetes menos heterogêneos - com partidos que possuem preferências ideológicas menos extremas à preferência do partido formador. A tendência verificada entre 2003 e 2014 é contrária. Nesse período houve aumento das taxas de controle da burocracia ministerial efetuado pelos parceiros da coalizão. Essa tendência está associada com a formação de gabinetes maiores e mais heterogêneos - com a presença de vários atores partidários com preferências ideológicas extremas às do partido formador. Os dados indicam que, para além da natureza accountable das ações de controle empreendidas pelos partidos da coalizão, o uso dessa prerrogativa de controle guarda relação com a expectativa de perda de informação dos partidos que ocupam o gabinete. Três pontos de inflexão representados no gráfico 3.1 são sintomáticos a esse respeito.

No primeiro ponto, no gabinete FHCI2 (1996), foi registrado o primeiro pico de controle das ações da burocracia ministerial. Nesse período, a taxa de controle horizontal mais que triplicou, variando de $16,2 \%$ no gabinete FHCI1 para 54,1\% no gabinete FHCI2. Esse efeito é decorrente da entrada do PPB no governo, um partido com preferência extrema ao partido formador e que desempenhou um papel ativo nas ações de controle (ver figura 3.1).

No segundo ponto, gabinete FHCII2 (2002), a taxa de controle da burocracia cai bruscamente $^{21}$ em função do governo menos heterogêneo formado nesse período. Por opção do presidente à época, Fernando Henrique Cardoso (PSDB), inúmeras pastas ministeriais foram distribuídas para ministros técnicos de sua cota pessoal. A nomeação destes técnicos foi viabilizada pela saída de um dos principais partidos parceiros no governo, o PFL, e pelo grande apoio legislativo de que gozava o presidente neste período. O governo passou a ser composto, principalmente, por ministros do partido do presidente ou por ministros técnicos por ele indicados. Assim, em decorrência da baixa taxa de partidarismo do gabinete, os incentivos para o controle horizontal foram reduzidos.

O terceiro ponto de inflexão ocorreu no gabinete LULAI1, o primeiro formado pelo presidente em 2003. Diferente do período FHC, o plano de conseguir implementar

${ }^{21}$ A taxa de controle horizontal no gabinete registrada neste ponto do tempo foi de $0,18 \%$. 
uma extensa agenda de políticas sociais foi viabilizado por uma densa rede de apoio político, razão pela qual o governo foi ocupado por partidos de diferentes matizes ideológicos e distintas preferências sobre políticas (Melo; Nunes, 2009). Esse gabinete registrou a maior taxa de partidarismo desde o início da série em 1995. O controle ex post sobre a implementação das políticas públicas foi uma estratégia recorrente entre os partidos integrantes do gabinete. No primeiro mandato da presidenta DILMA, também um governo marcado pela composição de gabinetes grandes e heterogêneos, é possível observar a mesma tendência de altas taxas de controle horizontal intragabinete em função da assimetria de informação decorrente da composição de governos multipartidários.

Está claro, portanto, que, na trajetória recente da democracia brasileira, a formação de gabinetes grandes e com preferências dispersas produz incentivos para a ocorrência de controle horizontal entre os partidos. Esse é, porém, apenas o componente empírico básico do argumento sustentado neste trabalho. Na continuidade deste capítulo, a relação sugerida será testada através de evidências empíricas produzidas a partir do mapeamento das redes de controle horizontal existentes no presidencialismo brasileiro.

\subsection{As redes de controle horizontal no presidencialismo brasileiro}

Para os especialistas que investigam as relações políticas conformadas entre o chefe de governo e seus parceiros no gabinete, nos últimos anos, a expressão "The Blackbox" se transformou numa espécie de sinônimo de "Executivo". O emprego do termo se presta ao objetivo de chamar a atenção para o fato de pouco se saber sobre os fluxos de informação que irrigam os acordos políticos firmados entre os atores que integram o governo.

Nesta seção, apresento as redes de controle formadas a partir do controle mútuo entre os partidos que integram o gabinete de governo. Mais especificamente, a partir da coleta de informações diádicas e da composição de sociomatrizes, foi possível mapear as redes de controle dos partidos na fase de implementação das políticas públicas do Executivo.

Dado um número $\mathrm{M}$ de atores que integram a rede de controle horizontal em cada gabinete formado entre 1995 e 2014, uma sociomatriz é composta pela interseção de $\mathrm{N}$ relacionamentos entre os partidos do gabinete - $\mathrm{M} \times \mathrm{M}-$, em que cada célula representa o relacionamento entre dois atores (partidos) e a força dessa relação. A força 
da relação é determinada pelo número de vezes que cada partido realiza ações de controle em relação a outro ator da rede.

Por exemplo, numa matriz (uma rede) hipotética $C M$, a força da relação entre o partido X e o partido Y será dada pelo número de ações de controle que cada partido executa sobre o outro. Se nessa mesma matriz hipotética $S$ é controlado 50 vezes e G é controlado 10 vezes, S estará necessariamente numa posição de maior centralidade na rede. A posição na rede é definida, dessa forma, pela intensidade de controle que cada ator executa e recebe. Atores mais centrais são aqueles que, num dado gabinete, foram mais controlados pelos outros partidos presentes no governo.

A tabela 3.1 apresenta as descritivas básicas das redes formadas nos 15 gabinetes analisados, nos governos FHC, LULA e DILMA. As redes foram construídas a partir de uma seleção aleatória estratificada ${ }^{22}$, levando em consideração os seguintes critérios: i. número de partidos que integram o gabinete; ii. duração do gabinete e; iii. peso de cada partido no gabinete em função do tempo de duração do gabinete. No total, foram amostradas 817 ações de controle do universo de 22.688 requerimentos de informação apresentados na Câmara dos Deputados entre 1995 e 2014.

O número de atores da rede informa quantos partidos participaram das ações de controle horizontal. Esse número será sempre maior que o número de partidos da coalizão em função dos partidos que não ocupam o governo, mas também realizam ações de controle. O número de relações da rede é o número de conexões estabelecidas pelos atores da rede. Esse número será sempre maior ou igual ao número de atores da rede. Isso porque cada ator pode controlar as ações de mais de um partido na mesma rede.

As colunas $\mathrm{CEC}^{23}$ e $\mathrm{CEO}^{24}$ da tabela 3.1 informam o controle efetivo dos partidos da coalizão (CEC) e o controle efetivo dos partidos da oposição (CEO). Tanto o CEC como o CEO têm a finalidade de ponderar a quantidade de ações de controle da coalizão e da oposição pelo número de partidos que integram a rede. Se, numa rede qualquer, os partidos da coalizão realizam 15 ações de controle através de 3 partidos, e os partidos da oposição realizam as mesmas 15 ações de controle através de 10 partidos,

\footnotetext{
22 Os estratos são os 15 gabinetes analisados. Em termos operacionais, isso significa que os sorteios foram realizados para cada gabinete considerando os critérios expostos acima.

${ }^{23} \mathrm{O}$ valor de CEC é dado pelo número ações de controle dos partidos da coalizão [A], ponderado pelo número de partidos da coalizão que realizaram ações de controle [B]. Em termos aritméticos: (A/B)/10.

${ }^{24} \mathrm{O}$ valor de CEO é dado pelo número ações de controle dos partidos da oposição [C], ponderado pelo número de partidos da oposição que realizaram ações de controle [D]. Em termos aritméticos: (C/D)/10.
} 
o controle executado pela coalizão é considerado mais efetivo, uma vez que os partidos da coalizão foram capazes de realizar, no mesmo tempo, a mesma frequência de controle com um número menor de atores na rede.

Os dois indicadores devem ser analisados de forma conjunta: vis-à-vis aos valores do CEO, maiores valores do CEC indicam maior controle efetivo dos partidos da coalizão. Como informa a tabela 3.1, o peso da coalizão nas redes de controle horizontal foi maior ou igual ao da oposição em $73.3 \%(11)^{25}$ dos gabinetes formados. Embora os partidos da oposição também desempenhem um papel no controle das ações ministeriais, a maior densidade das redes é explicada pelo controle executado pelos partidos da coalizão. Ou seja, as políticas públicas executadas pelo Executivo são, predominantemente, monitoradas pelos partidos da coalizão de governo. Esse dado vai de encontro à visão corrente de que são, os partidos da oposição, os atores mais interessados em escrutinar as ações de implementação do Executivo.

Alguns esclarecimentos adicionais acerca da composição das redes são necessários. As redes construídas são one $\operatorname{mode}^{26}$ e bidirecionais. No lugar de fazer uma rede two mode entre partidos e ministérios, optou-se por sempre considerar o partido do ministro que comanda o ministério. Dessa forma, falar que o PT controla o PSDB significa falar que o PT controla as ações de algum ministério - ou alguns ministérios do PSDB. Todas as redes são compostas por $\operatorname{nodes}^{27}$ que representam partidos e as setas representam o sentido do controle. Na primeira rede da figura 3.1, por exemplo, o PSDB é controlado por PL, PCdoB, PMDB, PSB, PPR e PT. O PSDB, por sua vez, controla o PFL, razão pela qual a seta sai do node deste partido (PSDB) em direção ao partido por ele controlado (PFL).

As redes formadas nos gabinetes foram classificadas em função da sua densidade. A densidade é definida pela razão entre as relações existentes em toda a rede e as relações possíveis de se existir $\left(\mathrm{k}^{2}\right)^{28}$. Assim, quanto mais densa for a rede, mais coesa será a cadeia de vínculos entre estes atores (Wasserman; Faust, 1994). O

\footnotetext{
25 Considerando a medida alternativa de tempo, o controle exercido pela coalizão foi mais efetivo em $5.817(76 \%)$ dos 7.655 dias de duração do gabinete, entre 1995 e 2014.

26 Redes compostas apenas por um tipo de elemento. Nesse caso, a unidade de análise fundamental em cada rede é o partido do ministro.

27 São as unidades gráficas que representam a unidade de análise fundamental de cada rede. Nas redes deste trabalho cada node represente um partido.

${ }^{28} \mathrm{O}$ cálculo das relações possíveis $(\mathrm{R})$ é realizado a partir da multiplicação do número total de atores da rede $(\mathrm{N})$ pelo número total de atores menos 1 [N-1]. Enquanto fórmula, R=N x N-1. Esta última subtração faz-se necessária pela impossibilidade de algum ator relacionar-se consigo mesmo.
} 
indicador "densidade (Z)" presente na tabela 3.1 corresponde às densidades padronizadas $^{29}$ das redes analisadas. Por meio da padronização, foi possível estabelecer um critério claro para a classificação das redes. As redes com valores acima de um desvio padrão positivo foram consideradas de alta densidade. Redes com valores acima de um desvio padrão negativo foram consideradas de baixa densidade. Redes com números entre 0 e 1 (positivo ou negativo) foram considerados de média densidade.

\footnotetext{
${ }^{29}$ A padronização em $\mathrm{Z}$ scores indica quantos desvios padrões um dado valor $\mathrm{X}$ de densidade se afasta da média padronizada de todas as redes analisadas.
} 
Tabela 3.1. Descritivas das redes de controle horizontal (RIC).

\begin{tabular}{|c|c|c|c|c|c|c|c|c|c|c|c|}
\hline Gabinete & $\begin{array}{c}\text { N. } \\
\text { Atores }\end{array}$ & N. Relações & $\begin{array}{l}\text { N. Ações de } \\
\text { Controle }\end{array}$ & $\begin{array}{c}\text { N. Coalizão } \\
{[A]}\end{array}$ & $\begin{array}{c}\text { Partidos Coalizão } \\
{[\mathrm{B}]}\end{array}$ & $\begin{array}{c}\text { N. Oposição } \\
{[C]}\end{array}$ & $\begin{array}{c}\text { Partidos Oposição } \\
\text { [D] }\end{array}$ & CEC & CEO & Densidade & Densidade $(Z)$ \\
\hline FHC I 1 & 10 & 15 & 20 & 3 & 3 & 17 & 7 & 0,10 & 0,24 & 16,67 & $-0,30$ \\
\hline FHC I 2 & 9 & 15 & 63 & 33 & 4 & 30 & 5 & 0,83 & 0,60 & 16,88 & $-0,28$ \\
\hline FHC II 1 & 10 & 17 & 47 & 25 & 4 & 22 & 6 & 0,63 & 0,37 & 18,89 & $-0,01$ \\
\hline FHC II 2 & 6 & 6 & 9 & 4 & 2 & 5 & 4 & 0,20 & 0,13 & 7,20 & $-1,56$ \\
\hline Lula I 1 & 14 & 19 & 65 & 24 & 7 & 41 & 7 & 0,34 & 0,59 & 20,46 & 0,20 \\
\hline Lula I 2 & 14 & 18 & 64 & 38 & 8 & 26 & 6 & 0,48 & 0,43 & 19,38 & 0,06 \\
\hline Lula I 3 & 8 & 8 & 13 & 7 & 4 & 6 & 4 & 0,18 & 0,15 & 9,14 & $-1,30$ \\
\hline Lula I 4 & 7 & 7 & 6 & 3 & 5 & 3 & 3 & 0,06 & 0,10 & 8,17 & $-1,43$ \\
\hline Lula I 5 & 10 & 24 & 68 & 37 & 7 & 31 & 3 & 0,53 & 1,03 & 26,67 & 1,02 \\
\hline Lula II 1 & 8 & 9 & 26 & 19 & 8 & 7 & 3 & 0,24 & 0,23 & 10,29 & $-1,15$ \\
\hline Lula II 2 & 15 & 27 & 72 & 17 & 8 & 55 & 7 & 0,21 & 0,79 & 28,93 & 1,33 \\
\hline Lula II 3 & 14 & 25 & 116 & 60 & 7 & 56 & 7 & 0,86 & 0,80 & 26,92 & 1,06 \\
\hline DilmaI1 & 14 & 20 & 84 & 43 & 7 & 41 & 7 & 0,61 & 0,59 & 21,54 & 0,34 \\
\hline DilmaI2 & 16 & 23 & 73 & 26 & 7 & 47 & 14 & 0,37 & 0,34 & 24,53 & 0,74 \\
\hline DilmaI3 & 17 & 27 & 91 & 33 & 6 & 58 & 11 & 0,55 & 0,53 & 28,69 & 1,29 \\
\hline
\end{tabular}

Fonte: elaborado pelo autor a partir dos dados da Câmara dos Deputados. 
O que qualifica o grupo das redes de baixa densidade é o pequeno número de atores e a baixa frequência de relações entre os atores. $\mathrm{O}$ baixo grau de heterogeneidade do gabinete FHCII2 é explicado pela pequena quantidade de atores e relações observados nessa rede. Em tais contextos, ainda que presente, a expectativa de perda de informação dos partidos que integram o governo é menor.

No caso das três redes (LULAI3, LULAI4 e LULAII1) de baixa densidade formadas durante os mandatos do presidente LULA, é preciso considerar o pouco tempo de duração destes gabinetes. Ainda que nesses governos o nível de dispersão das preferências ideológicas seja alto, a média de 86 dias de duração dos gabinetes não configura tempo suficiente para que os conflitos intragabinete possam se expressar na arena parlamentar e suscitar controle por parte dos partidos da coalizão. Dessa forma, apenas as redes com média e alta densidade seguem apresentadas na sequência ${ }^{30}$.

As redes de média densidade do período FHC se distinguem das redes formadas nos governos LULA e DILMA pela magnitude da densidade. No primeiro caso, as redes de média densidade sempre apresentam densidades padronizadas negativas; ao passo que nos outros dois casos, as densidades padronizadas são sempre positivas. Isso indica, em primeiro lugar, que o número de atores e relações entre os partidos observados nas redes dos governos LULA e DILMA é sempre maior. Significa, também, que a prática de controle mútuo entre os parceiros de gabinete é mais comum quando comparado com os gabinetes formados no governo FHC. Nesses governos, o controle mútuo intragabinete ocorre de forma mais recorrente e com maior intensidade.

\footnotetext{
${ }^{30}$ As redes de baixa densidade podem ser visualizadas no apêndice $\mathbf{B}$ deste trabalho.
} 
Figura 3.1. Redes de média densidade.

\section{FHCI1}

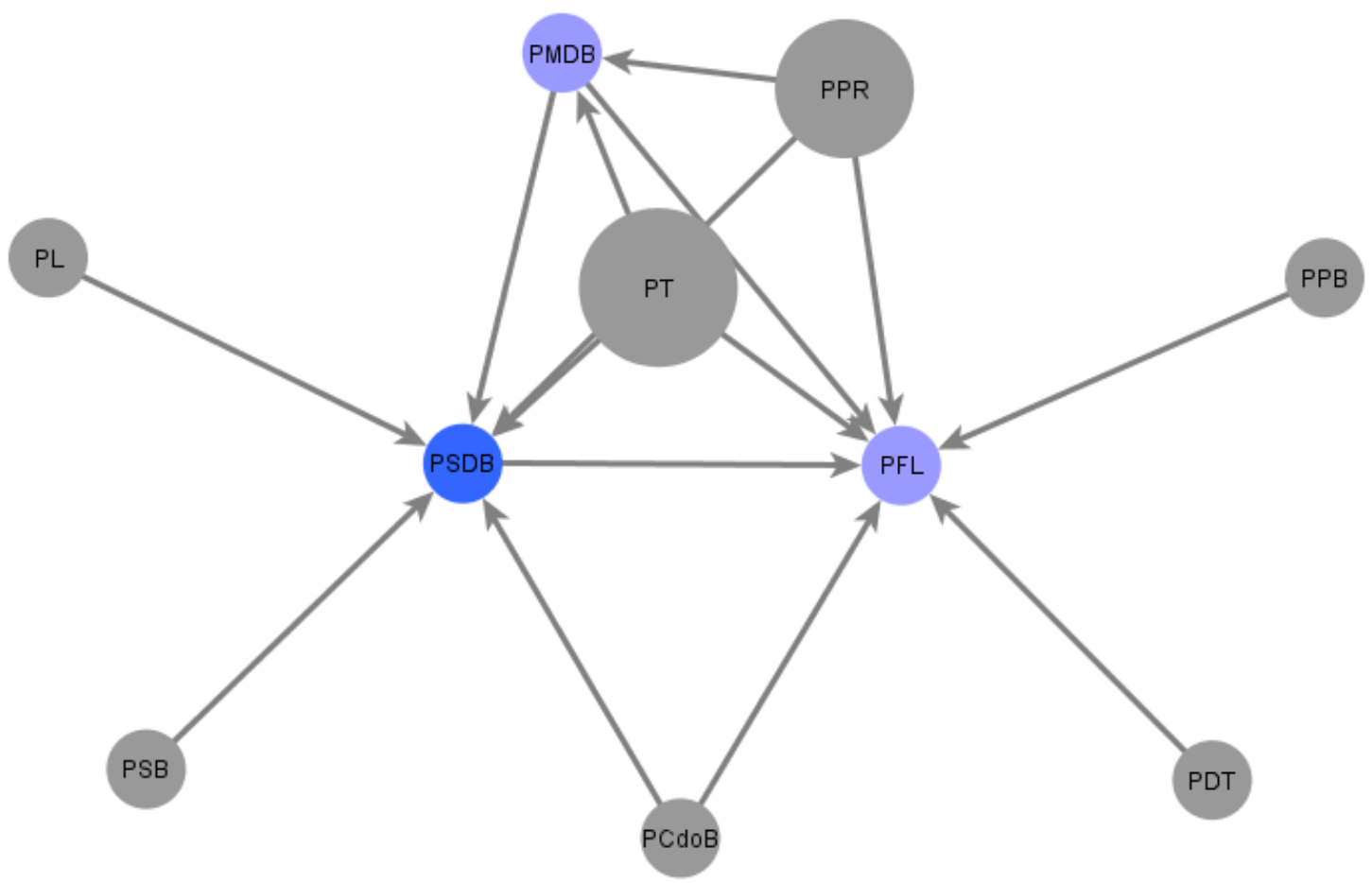

FHCI2

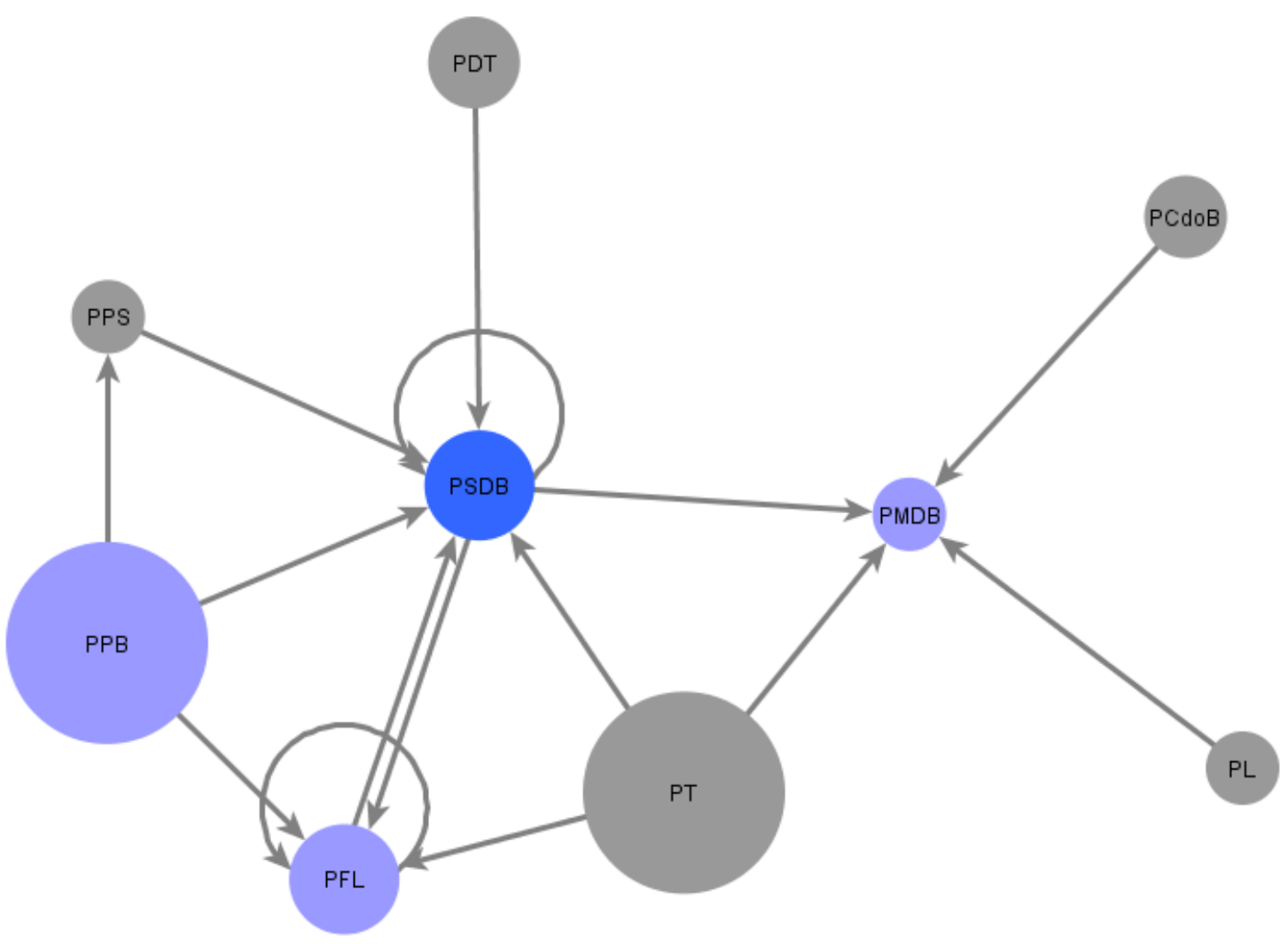




\section{FHCII1}
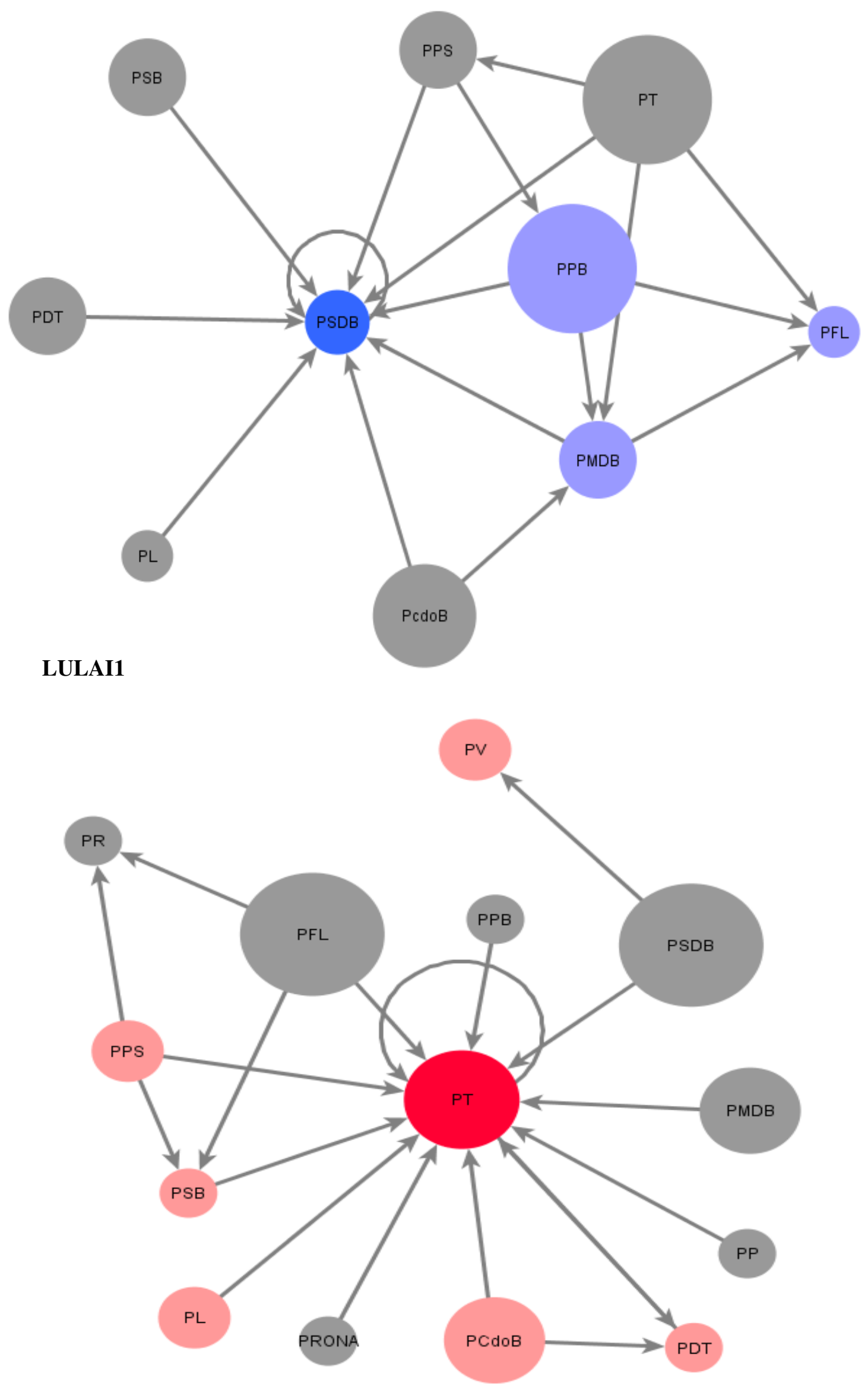

53 | Pá g i n a 


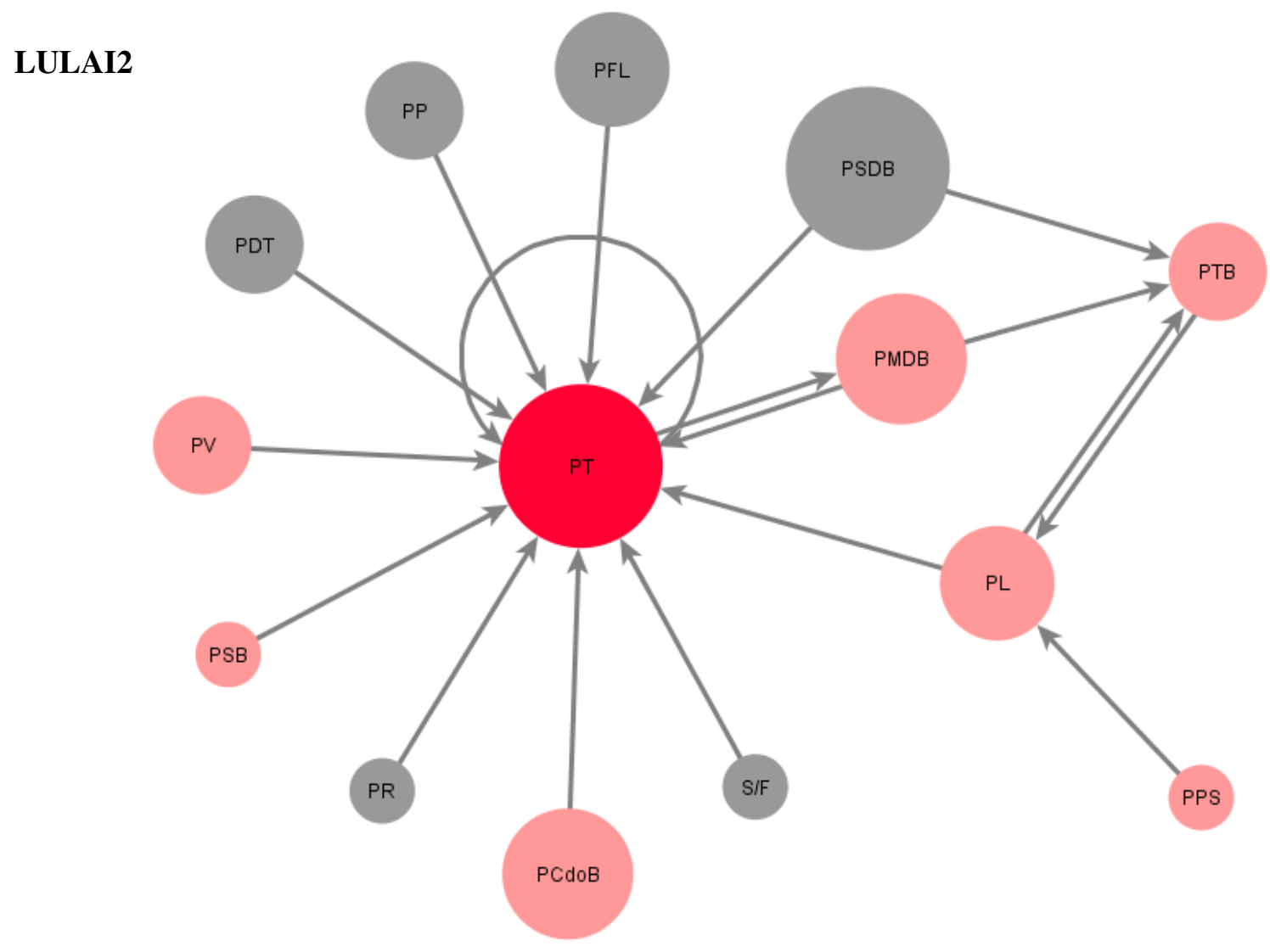

DILMAI

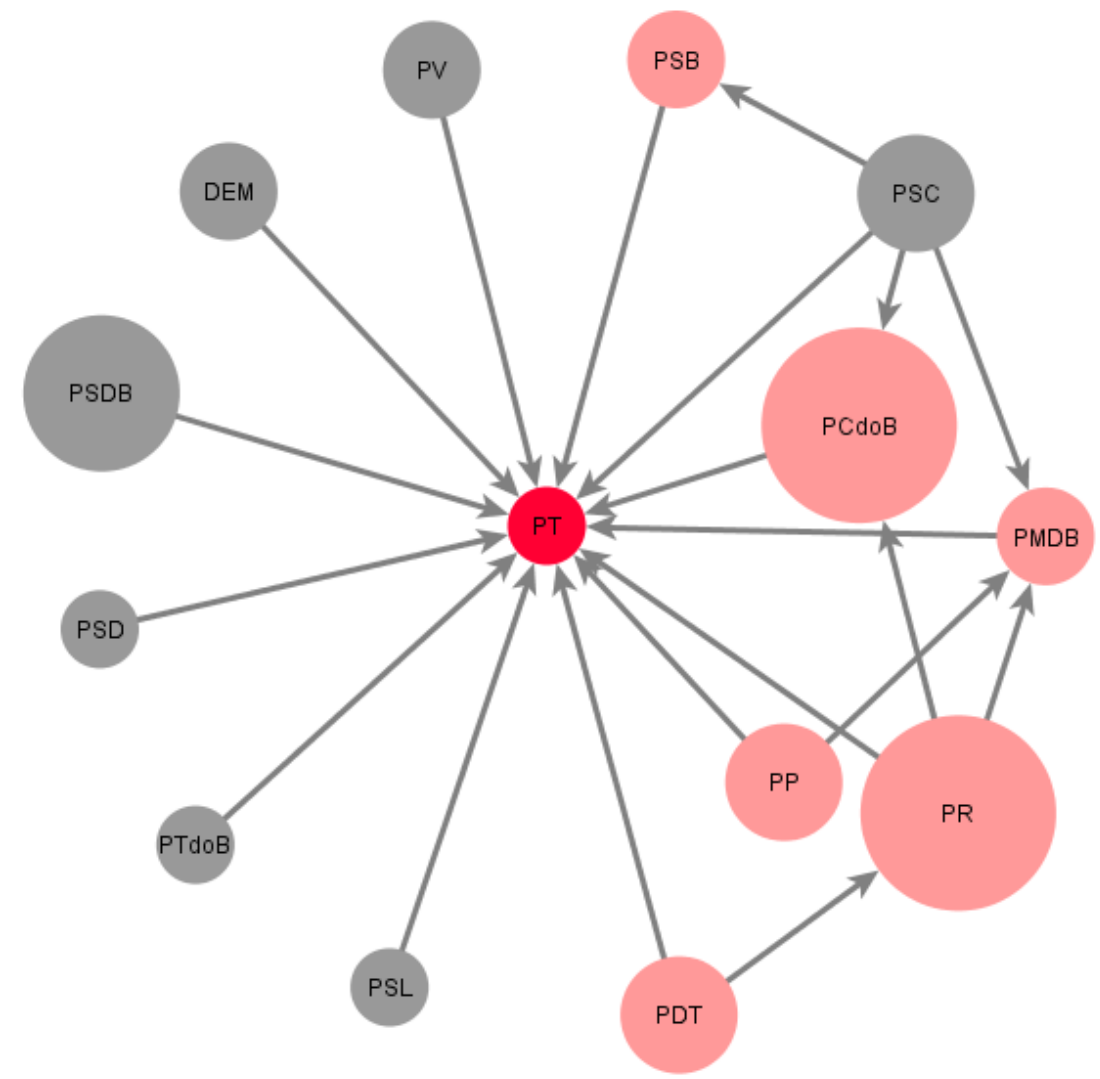

54 | Pá g i n a 


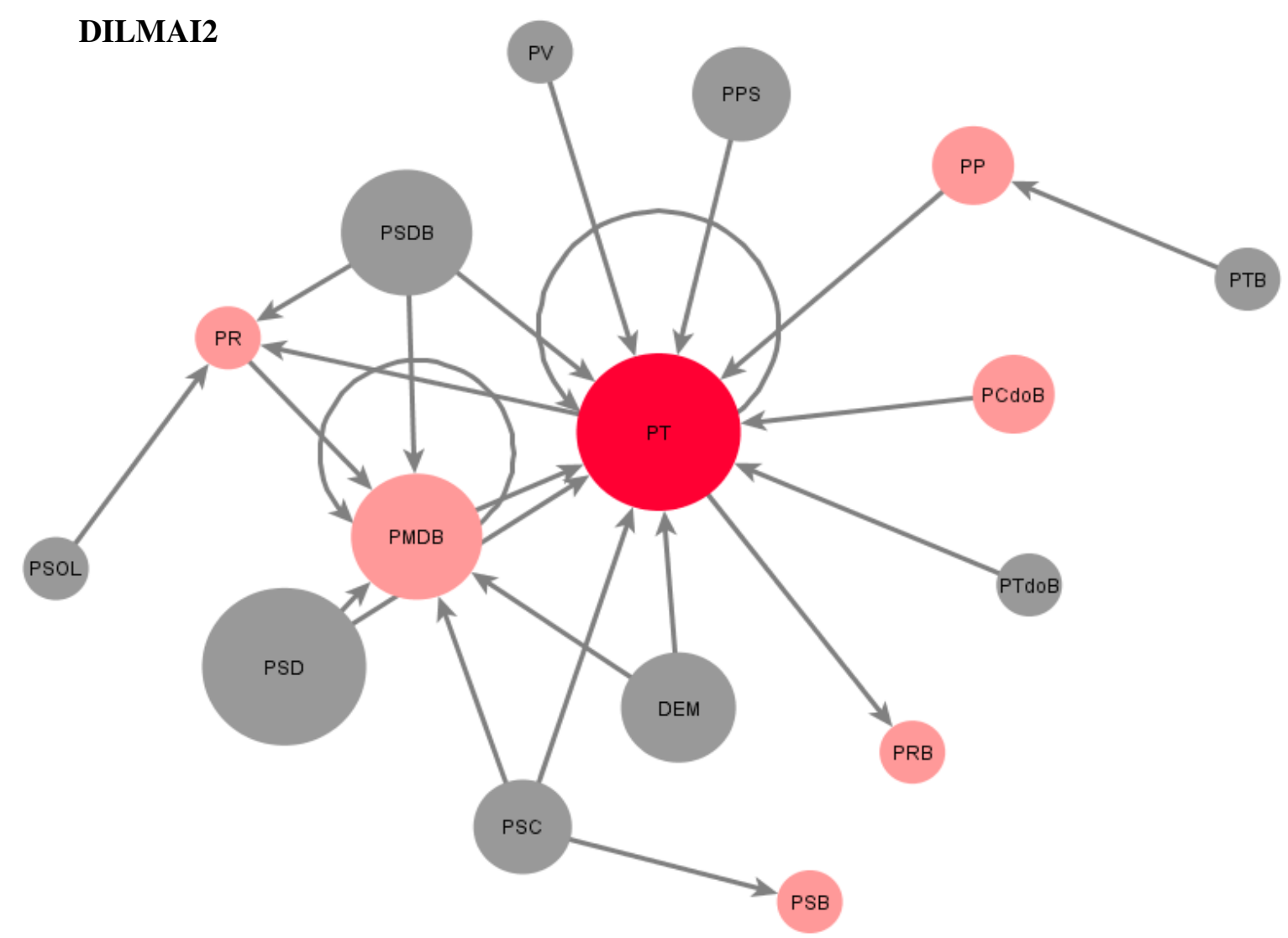

Nos gabinetes dos governos LULA e DILMA, para além dos fluxos de controle na direção do partido formador, observa-se a cristalização da tendência do fluxo inverso. Isto é, o partido formador passa a controlar de forma persistente as áreas de policy delegadas para outros atores, inclusive aquelas entregues para ministros do seu próprio partido $^{31}$. Essas redes mais densas de controle observadas não são particulares aos governos petistas, mas uma decorrência dos custos envolvidos na constituição de complexas cadeias de delegação. Gabinetes heterogêneos aumentam a expectativa de assimetria de informação dos partidos integrantes do gabinete e fomentam o mútuo controle durante o processo de implementação de políticas públicas.

Outro fluxo observado de maneira mais intensa nos gabinetes dos governos LULA e DILMA é o aumento do controle entre os parceiros do gabinete que não o partido formador. Nesse sentido, destaca-se o movimento de aumento do controle sobre o principal partido parceiro ${ }^{32}$ do chefe de governo. É demonstrativo disso, o deslocamento progressivo do PMDB para o centro da rede e o protagonismo do PCdoB

\footnotetext{
${ }^{31} \mathrm{O}$ Controle das áreas ministeriais controladas por ministros do próprio partido é indicado na rede pelas setas que saem e entram no mesmo node de um determinado ator. Estas setas são chamadas de Tie Loop.

${ }^{32}$ Neste trabalho, o termo "principal partido parceiro do gabinete" será utilizado para se referir ao partido que, depois do partido do Presidente, mais recebe recurso para implementar políticas.
} 
- o partido com menor média ${ }^{33}$ de recursos do orçamento federal entre 2003 e 2014 - nas iniciativas de controle das redes de controle horizontal.

Entre 2003 e 2014, o PCdoB só não recebeu menos recursos da LOA nos gabinetes DILMAI2 e DILMAI3, os dois últimos do primeiro mandato da presidenta Dilma Rousseff. Nessas ocasiões, o PRB, que controlava a pasta da pesca e aquicultura, teve à sua disposição apenas $0,09 \%$ e $0,12 \%$, respectivamente, do orçamento federal para a realização de políticas. Ser o partido com menos recursos para policy significa também estar distante do processo de implementação de uma série de importantes áreas ministeriais. A alternativa para diminuir a assimetria de informação em relação aos parceiros de gabinete com mais recursos é o controle das ações de implementação de políticas públicas. O controle horizontal é a forma menos custosa e eficiente de conhecer as políticas dos parceiros da coalizão e de monitorar as ações de diferentes ministérios de acordo com as prioridades do partido. Como mostrarei no capítulo 5, essa estratégia ajuda a explicar por que os partidos com médio e baixo peso legislativo aceitam integrar coalizões de governo no Brasil.

\footnotetext{
${ }^{33}$ Média de $0,39 \%$ da LOA.
} 
Figura 3.2. Redes de alta densidade.
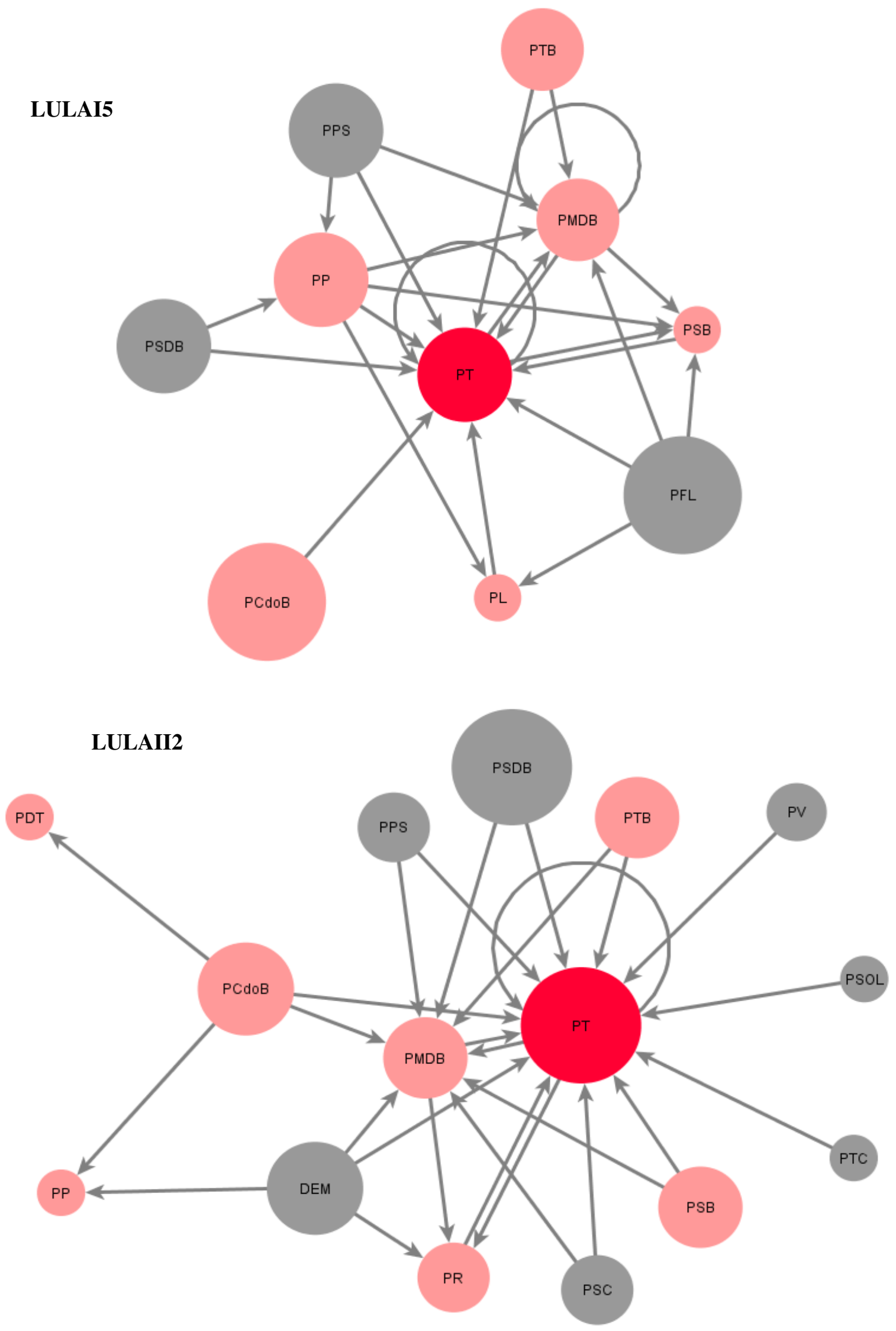

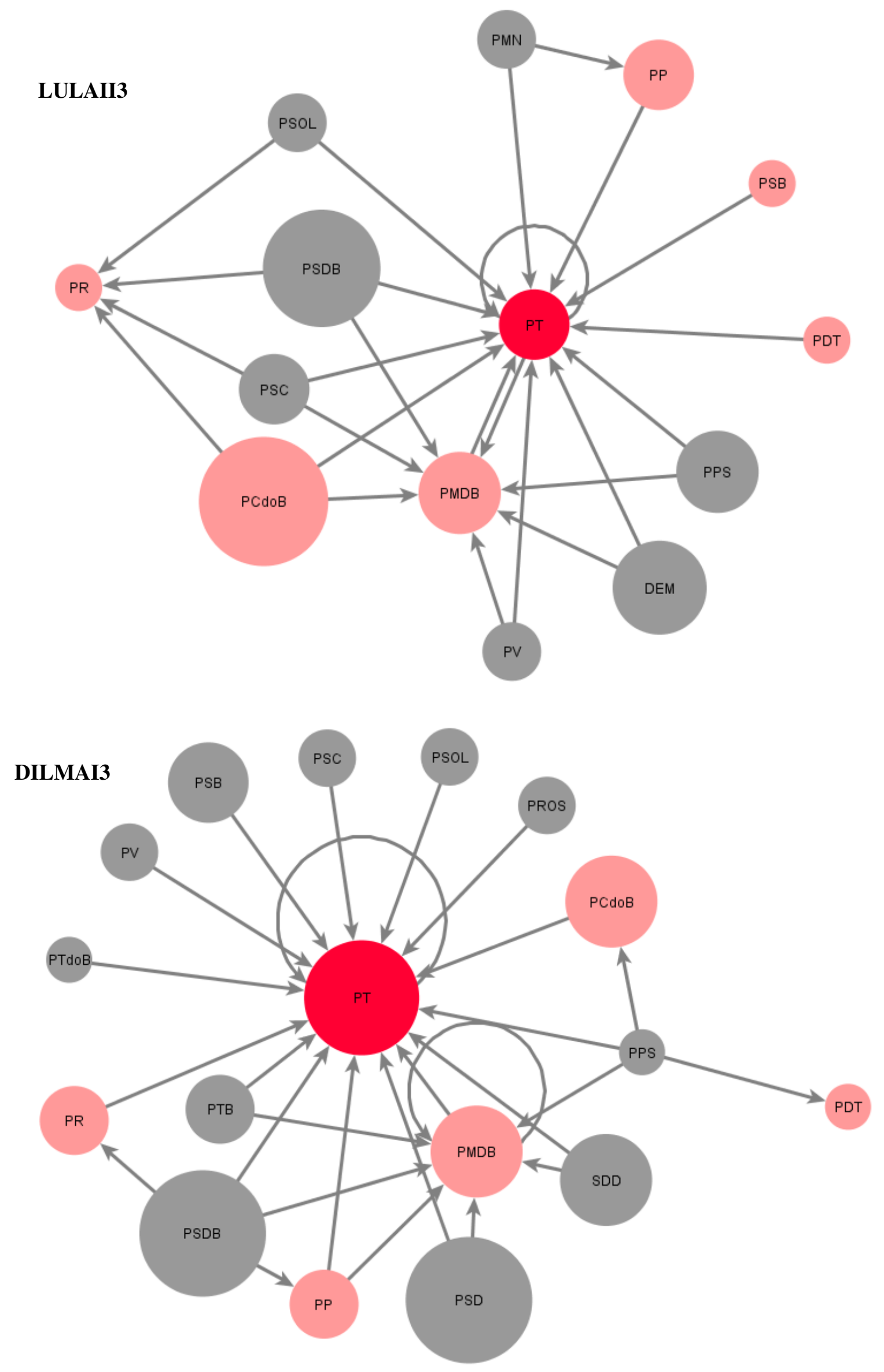
Na próxima seção dou um passo além da descrição visual das redes de controle horizontal. Até este momento, a relação sugerida entre a constituição de redes de controle mais densas e o grau de dispersão de preferências no gabinete esteve assentada numa derivação teórica extraída dos modelos formais de delegação ${ }^{34}$. O objetivo da próxima seção é consubstanciar a correlação sugerida a partir de testes empíricos inferenciais. Feito isso, os atributos e fluxos observados nas redes de controle horizontal poderão ser utilizadas como evidências empíricas do mecanismo causal sugerido neste capítulo.

\subsection{Determinantes do controle horizontal (RIC) no presidencialismo brasileiro}

$\mathrm{Na}$ seção anterior, discuti as principais características das redes de controle horizontal constituídas nos 15 gabinetes multipartidários formados nos governos FHC, LULA e DILMA. Argumentei que a variação do grau de densidade das redes está relacionada com a dispersão das preferências partidárias no gabinete de governo.

Nesta subseção, testo, de forma sistemática, a hipótese de que os partidos da coalizão intensificam o controle quando a expectativa de assimetria de informação aumenta. Trata-se da seguinte questão: a probabilidade de que ações de controle de políticas públicas sejam executadas por um partido da coalizão aumenta nos contextos em que o gabinete de governo é composto por preferências ideológicas dispersas?

Para responder a questão, utilizo o modelo multivariado que se segue:

$$
\begin{gathered}
\operatorname{Pr}\left[S_{i}=1\right]=\log i t^{-1} \\
{\left[\alpha+\beta_{1} h i_{i}+\beta_{2} n p_{i}+\beta_{3} t c_{i}+\beta_{4} d c_{i}+\beta_{5} d o_{i}+\varepsilon i\right]}
\end{gathered}
$$

A variável dependente $S_{i}$ assume o valor 1 quando o parlamentar que apresenta o requerimento de informação - a proposta de controle horizontal - pertence ao partido da coalizão. Se o parlamentar pertence a qualquer outro partido $S_{i}$ assume o valor 0. A probabilidade de ocorrência desse evento é uma função das seguintes variáveis:

[hi] - medida do grau de heterogeneidade ideológica dos partidos que integram o gabinete de governo. Esse é o mesmo indicador utilizado por Power e Zucco (2009) e Zucco e Lauderdale (2011) e presente na tabela 2.1 do capítulo dois:

34 Priori Logical Modeling 
[np] - número de partidos que compõe o gabinete de governo;

[tc] - proporção de partidos representados no Legislativo e que integram a coalizão de governo;

[dc] - indicador que mensura a taxa de apoio - disciplina legislativa - dos partidos da coalizão às propostas de políticas do Executivo;

[do] - indicador que mensura a taxa de apoio - disciplina legislativa - dos partidos da oposição às propostas de políticas do Executivo.

O principal regressor do modelo é o indicador de heterogeneidade ideológica [hi] do gabinete. Espero que quanto maior a dispersão das preferências partidárias no gabinete, maior a probabilidade de controle horizontal executado por parlamentares de partidos da coalizão. Os indicadores [np] e [tc] são medidas alternativas de heterogeneidade do gabinete. Portanto, também espero sinal positivo e significante nos dois casos.

Tabela 3.2. Descritivas das variáveis utilizadas nos modelos Logit e Poisson.

\begin{tabular}{|c|c|c|c|c|c|}
\hline Variáveis & $\mathbf{N}$ & Média & $\begin{array}{l}\text { Desvio } \\
\text { Padrão }\end{array}$ & Min & Max \\
\hline \multicolumn{6}{|c|}{ Modelos Logit } \\
\hline V. Dependente & 817 & 0.3782 & 0.4852 & 0 & 1 \\
\hline Ciclo Eleitoral & 817 & 695.77 & 436.41 & 18.39 & 1454.12 \\
\hline $\mathrm{dc}$ & 817 & 0.8342 & 0.0751 & 0.6919 & 0.9207 \\
\hline hi $^{1}$ & 817 & 0.7237 & 0.1163 & 0.25 & 0.91 \\
\hline Honey & 817 & 0.3170 & 0.4655 & 0 & 1 \\
\hline $\mathrm{np}$ & 817 & 6.95 & 1.28 & 3 & 8 \\
\hline tc & 817 & 0.6209 & 0.0825 & 0.4269 & 0.7719 \\
\hline \multicolumn{6}{|c|}{ Modelos Poisson } \\
\hline V.Dependente & 80 & 313.01 & 193.77 & 37 & 1219 \\
\hline Ciclo Eleitoral & 80 & 693.21 & 423.71 & 2 & 1397 \\
\hline $\mathrm{dc}$ & 80 & 0.8291 & 0.1090 & 0.4848 & 0.9890 \\
\hline hi $^{1}$ & 80 & 0.4912 & 0.1363 & 0.1301 & 0.7065 \\
\hline Honey & 80 & 0.25 & 0.4357 & 0 & 1 \\
\hline $\mathrm{np}$ & 80 & 6.26 & 1.76 & 3 & 8 \\
\hline Popularidade & 80 & 42.98 & 16.05 & 13.75 & 83 \\
\hline tc & 80 & 0.6367 & 0.0905 & 0.4260 & 0.7719 \\
\hline
\end{tabular}

Fonte: CEBRAP. ${ }^{1}$ Elaborado pelo autor a partir de Power e Zucco (2009).

A inclusão dos indicadores que predizem o relacionamento entre Executivo e Legislativo tem por objetivo controlar o teste de hipótese por duas medidas que 
explanam argumentos rivais. Em relação à primeira delas, [dc], espero que não haja correlação estatisticamente significante dessa variável com a probabilidade dos partidos realizarem ações de controle horizontal. Não apoiar as propostas enviadas pelo Executivo ao Congresso é uma medida drástica e relacionada com o processo de formulação das políticas. Mesmo que os partidos da coalizão se comportem de maneira disciplinada em todas as votações no Legislativo, dado o objetivo de monitorar os parceiros do gabinete responsáveis pelas políticas de seu interesse, os partidos empreenderão ações de controle horizontal. Dessa forma, os partidos têm interesse em monitorar até mesmo as políticas por eles endossadas no Congresso.

No caso do segundo indicador da relação Executivo - Legislativo [do], pelo mesmo raciocínio desenvolvido no caso do indicador [dc], espero que não haja uma correlação significante entre esse indicador e a probabilidade de redução do controle efetuado pelos parceiros da coalizão. No caso dos partidos da oposição, o argumento pode ser radicalizado em virtude do menor - ou nenhum - compromisso dos partidos da oposição com a agenda de políticas do Executivo, e pelo maior afastamento deste às ações implementadas pela burocracia do governo. Para esses partidos, a falta de informação em relação à implementação das políticas do seu interesse é ainda maior.

A tabela 3.3 apresenta os resultados dos modelos logísticos ajustados. No primeiro modelo (I), o indicar de heterogeneidade ideológica do gabinete foi regredido apenas na presença dos controles de tempo, Ciclo Eleitoral e Honey. O primeiro deles é uma tentativa de controlar algum viés proveniente da proximidade ou não com as eleições. No caso do controle Honey, busca-se controlar o efeito temporal do mandato, sob a hipótese de que nos primeiros doze meses de governo do presidente as ações de fiscalização do Legislativo são menos intensas. Nesse modelo, o indicador [hi] é positivo e significante. A cada acréscimo de um ponto na escala de heterogeneidade ideológica, a probabilidade de um partido da coalizão efetuar controle horizontal sobre um parceiro aumenta 90\% (ou 6.7 vezes). 
Tabela 3.3. Modelos Logit multivariados.

\section{Variáveis}

(I)

(II)

(III)

V. Dependente ${ }^{35}=$ Se o Partido que executa o controle faz parte da Coalizão

\section{Características do Gabinete}

[hi] Heterogeneidade Ideológica

$$
1.905^{* * *}
$$

$1.559 * *$

$1.334 *$

[np] Número de Partidos do Gabinete

(0.657)

$(0.707)$

(0.773)

0.0498

0.124

(0.0656)

$(0.139)$

[tc] Tamanho da Coalizão

$2.903 * * *$

(1.042)

\section{Relação Executivo - Legislativo}

[dc] Disciplina da Coalizão

0.00617

(0.0275)

[do] Disciplina da Oposição

$-0.00868$

(0.0287)

\section{Controles}

Ciclo Eleitoral
Honey

Constante

Log likelihood
Sim

Sim

$-2.114 * * *$

(0.492)

$-535.1$
Sim

Sim

$-4.036^{* * * *}$

(0.960)

$-530.8$

817
Sim

Sim

\section{$\mathbf{N}$}

817

Erro padrão robusto entre parênteses

$* * * \mathrm{p}<0.01, * * \mathrm{p}<0.05, * \mathrm{p}<0.1$

No segundo modelo (II), os outros indicadores de heterogeneidade de preferências partidárias foram acrescentados e regredidos na presença dos controles de tempo. Assim como o esperado, [np] e [tc] apresentam sinal positivo. No entanto, apenas [tc] apresenta significância. Importa salientar que, na presença dos novos

\footnotetext{
${ }^{35}$ A variável dependente é categorizada da seguinte forma: Controle $=1$ se o deputado que pratica a ação de controle pertence a um partido da coalizão. Controle $=0$ se o deputado pertence a qualquer outro partido com representação no Legislativo
} 
controles, o indicador [hi] mantém seu efeito positivo e significante. $\mathrm{O}$ acréscimo de um ponto na escala de heterogeneidade ideológica implica aumento de 55\% (ou 4.75) na probabilidade de um partido da coalizão realizar controle horizontal da burocracia ministerial. Em consonância com este resultado, à medida que o tamanho da coalizão de governo aumenta $1 \%$, a probabilidade de um parlamentar de um partido dessa mesma coalizão empreender uma ação de controle aumenta 190\% (ou 18.2 vezes).

Por fim, no terceiro modelo (III), foram acrescidos os controles [dc] e [do] relacionados às hipóteses rivais. Em conformidade com a expectativa teórica deste capítulo, os dois indicadores não apresentam significância estatística. Além disso, os indicadores [hi] e [tc] mantém o sinal e efeitos apresentados nos dois modelos anteriores. Mantidos todos os fatores constantes, o incremento de um ponto na escala de heterogeneidade ideológica produz um acréscimo de 28,8\% (ou 3,6 vezes) na probabilidade de um parlamentar do partido da coalizão efetuar controle horizontal. Da mesma forma, aumentar o tamanho da coalizão em 1\% implica acréscimo de 149\% (ou 12,1 vezes) na probabilidade do controle da burocracia ministerial ser realizado por um partido do gabinete.

Temos, portanto, que, ceteris paribus, os incentivos para que os partidos do gabinete empreendam ações de controle da burocracia ministerial de seus parceiros aumentam consideravelmente quando existe maior expectativa de perda de informação. No entanto, é preciso averiguar, ainda, se, de fato, gabinetes mais heterogêneos implicam maiores taxas de incidência de controle horizontal. Para tanto, foram ajustados quatro modelos de Poisson apresentados na tabela 3.4.

Os 22.688 requerimentos de informação apresentados na Câmara dos Deputados, entre 1995 e 2014, foram agrupados em 80 unidades de tempo trimensais, com o objetivo de captar o efeito da heterogeneidade do gabinete sobre a incidência de ações de controle de políticas públicas. Além dos controles [hi], [np] e [tc] apresentados na tabela 3.2 e incluídos nos modelos logísticos (tabela 3.3), foi incluída uma variável ("Popularidade") como controle de fator exógeno, que mensura a taxa de aprovação do Presidente em cada uma das unidade de tempo. O objetivo é avaliar se o efeito dos indicadores de heterogeneidade se mantém na presença dos controles endógenos indicadores do gabinete e da relação Executivo-Legislativo -e exógenos - popularidade do Presidente -, controlando os efeitos fixos de cada governo. 


$$
\begin{gathered}
P_{r}(r, t)=\frac{e^{-\lambda} \lambda^{k}}{k !} \\
{\left[\alpha+\beta_{1} h i_{i}+\beta_{2} n p_{i}+\beta_{3} t c_{i}+\beta_{4} \operatorname{pop}_{i} \beta_{5} \operatorname{gov}_{i}+\mathcal{E}^{i]}\right.}
\end{gathered}
$$

No primeiro modelo (I), o indicar de heterogeneidade ideológica [hi] do gabinete foi regredido na presença dos controles de tempo, Ciclo Eleitoral e Honey, e do controle de fator exógeno Popularidade. As outras medidas de heterogeneidade do gabinete, [np] e [tc], também foram incluídas neste modelo. Os resultados evidenciam que, a cada acréscimo de um ponto percentual na escala de heterogeneidade ideológica, a taxa de incidência (IRR) de controle de políticas públicas - via requerimentos de informação aumenta cerca de 1,15 . Isso significa que, em relação à média, o número de ações de controle mais que dobra. O impacto dos indicadores [np] e [tc] é de, respectivamente, 1,16 e 1,91 .

Nos modelos II, III e IV, os mesmos controles são mantidos, variando os efeitos fixos de cada governo. No modelo II, quando o governo FHC é considerado, o indicador [hi], apesar de positivo, não é significante. Nos governos LULA (modelo III) e DILMA (modelo IV) o mesmo indicador é positivo e significante. Esse resultado pode ser explicado pela menor dispersão ideológica e, consequentemente, menor incidência de ações de controle executadas pelos partidos da coalizão no governo FHC. Dado que a grande variação nas taxas de controle é explicada pelos requerimentos de informação apresentados pelos partidos representados no gabinete, a incidência de controle nos governos LULA e DILMA é significativamente maior. Os resultados da análise de variância apresentados na tabela 3.4 testificam este argumento. 
Tabela 3.4. Modelos Poisson multivariados.

\begin{tabular}{|c|c|c|c|c|}
\hline Variáveis & (I) & (II) & (III) & $(\mathbf{I V})$ \\
\hline \multicolumn{5}{|c|}{ V. Dependente $=$ Número de RIC apresentados em cada unidade de tempo } \\
\hline \multicolumn{5}{|c|}{ Características do Gabinete } \\
\hline & & & R] & \\
\hline [hi] & $\begin{array}{l}1.1538 * * \\
(0.0789)\end{array}$ & $\begin{array}{c}1.0344 \\
(0.0731)\end{array}$ & $\begin{array}{c}2.5552 * * * \\
(0.2046)\end{array}$ & $\begin{array}{c}3.2015 * * * \\
(0.2745)\end{array}$ \\
\hline [np] & $\begin{array}{c}1.1620 * * * \\
(0.0070)\end{array}$ & $\begin{array}{c}1.2705 * * * \\
(0.0192)\end{array}$ & $\begin{array}{c}1.2130 * * * \\
(0.0076)\end{array}$ & $\begin{array}{c}1.0829 * * * \\
(0.0074)\end{array}$ \\
\hline [tc] & $\begin{array}{c}1.9147 * * * \\
(0.1756)\end{array}$ & $\begin{array}{c}1.7131 * * * \\
(0.1587)\end{array}$ & $\begin{array}{c}1.0881 \\
(0.1030)\end{array}$ & $\begin{array}{c}1.2079 * * \\
(0.1139)\end{array}$ \\
\hline
\end{tabular}

Fator Exógeno

$\begin{array}{ccccc}\text { Popularidade } & 0.9868 * * * & 0.9860 * * * & 0.9877 * * * & 0.9885 * * * \\ & (0.0006) & (0.0006) & (0.0006) & (0.0006)\end{array}$

\section{Controles}

\begin{tabular}{|c|c|c|c|c|}
\hline Ciclo Eleitoral & Sim & Sim & Sim & Sim \\
\hline Honey & Sim & Sim & Sim & Sim \\
\hline FHC & Não & Sim & Não & Não \\
\hline LULA & Não & Não & Sim & Não \\
\hline DILMA & Não & Não & Não & Sim \\
\hline Constante & $\begin{array}{c}114.99 * * * \\
6.783\end{array}$ & $\begin{array}{c}69.610^{* * * *} \\
7.122\end{array}$ & $\begin{array}{c}76.688^{* * * *} \\
5.684\end{array}$ & $\begin{array}{c}93.874 * * * \\
6.783\end{array}$ \\
\hline $\begin{array}{c}\mathrm{N} \\
\text { Unidades } \\
\text { Tempo }\end{array}$ & 22.688 & 22.688 & 22.688 & 22.688 \\
\hline Log likehood & -3630.93 & -3610.27 & -3397.93 & -3401.54 \\
\hline
\end{tabular}

No lugar de apresentar um teste de médias agregado para todas as categorias, através do teste de Tukey é possível comparar e testar se a diferença da proporção de controle realizada pela coalizão em cada governo é estatisticamente significante. A tabela 3.5 apresenta o teste de diferença das proporções entre as dez combinações possíveis, nos dois mandatos do presidente FHC e LULA e no primeiro mandato da presidenta DILMA. As maiores diferenças verificadas estão entre o segundo mandato 
do presidente FHC (FHCII) e os três mandatos dos presidentes petistas (LULAI, LULAII, DILMAI). Diferenças, todas elas estatisticamente significantes, que podem ser explicadas pela menor heterogeneidade observada nos gabinetes compostos no último quadriênio de governo FHC. É preciso ressaltar, ainda, a diferença estatisticamente significante registrada entre os dois mandatos do presidente FHC. A saída do PFL da coalizão de governo e a nomeação de um elevado número de ministros técnicos (da cota do presidente) explicam a menor incidência de controle da categoria FHCII. No caso das comparações realizadas entre as categorias referentes aos presidentes LULA e DILMA, como era de se esperar, a diferença das proporções é baixa e não apresenta significância estatística, em razão de os dois governos terem sido igualmente marcados pela composição de gabinetes grandes e heterogêneos, apresentando proporção de controle similar.

Tabela 3.5. Teste de Tukey (análise de variância) - proporção de controle (RIC) executado pela coalizão em cada governo (FHC, LULA e DILMA).

\begin{tabular}{ccccccc}
\hline Categoria & Diferença (prop) & SD & T & p value & \multicolumn{2}{c}{ Inter. Confiança (95\%) } \\
\hline FHCII vs FHCI & -0.1205 & 0.0425 & -2.83 & 0.045 & -0.2391 & -0.0018 \\
LULAII vs LULAI & -0.0430 & 0.0310 & -1.38 & 0.640 & -0.1296 & 0.0436 \\
DILMAI vs LULAI & -0.0013 & 0.0310 & -0.04 & 1.000 & -0.0880 & 0.0853 \\
DILMAI vs LULAII & 0.0416 & 0.0347 & 1.20 & 0.752 & -0.0552 & 0.1385 \\
LULAII vs FHCI & 0.0545 & 0.0388 & 1.40 & 0.682 & -0.0538 & 0.1628 \\
DILMAI vs FHCI & 0.0961 & 0.0388 & 2.67 & 0.058 & -0.0121 & 0.2045 \\
LULAI vs FHCI & 0.0975 & 0.0356 & 2.74 & 0.057 & -0.0018 & 0.1968 \\
LULAII vs FHCII & 0.1750 & 0.0388 & 4.50 & 0.000 & 0.0666 & 0.2833 \\
DILMAI vs FHCII & 0.2166 & 0.0388 & 5.57 & 0.000 & 0.1083 & 0.3250 \\
LULAI vs FHCII & 0.2180 & 0.0356 & 6.12 & 0.000 & 0.1186 & 0.3173 \\
\hline
\end{tabular}

Fonte: elaborado pelo autor a partir dos dados do NECI/USP.

Em suma, todas as evidências apontam na direção da principal hipótese deste trabalho. A delegação em governos com múltiplas preferências desencadeia conflitos intragabinete que se expressam no parlamento sob a forma de controle horizontal. Os partidos da coalizão não são indiferentes às áreas ministeriais controladas por seus parceiros e monitoram, por meio dos requerimentos de informação, as políticas públicas do seu interesse. Na próxima subseção, qualificarei essas ações de controle a partir da consideração dos atributos dos partidos representados nas redes. O que torna um partido do gabinete potencial alvo de controle dos seus parceiros? 


\subsection{O que têm os partidos controlados: atributos dos atores partidários nas redes de controle horizontal}

$\mathrm{Na}$ seção [3.2], argumentei que os requerimentos de informação são usados pelos partidos da coalizão como estratégia de controle das políticas públicas implementadas pelos seus parceiros de gabinete. Mostrei, na subseção [3.3], que essas redes de controle se complexificam e tornam-se mais densas de acordo com o grau de heterogeneidade ideológica do gabinete de governo. A assimetria de informação ensejada pela delegação cria incentivos para o controle mútuo no gabinete e aumenta a probabilidade de que os requerimentos de informação sejam apresentados pelos partidos da coalizão [subseção 3.4].

Nesta subseção, analiso os atributos dos atores centrais nas redes de controle intragabinete. O que determina a centralidade - receber maior volume de controle horizontal - de um ator nessas redes? Seria a posição na rede de controle horizontal uma função da quantidade de recursos para policy de que esses atores dispõem?

A tabela 3.6 apresenta o ranking dos partidos em cada gabinete, de acordo com o grau de centralidade ${ }^{36}$ dos partidos nas redes de controle horizontal. O ranking está disposto em ordem decrescente, do partido que recebeu mais controle dos seus parceiros do gabinete (1), para o partido que recebeu menor volume de controle dos parceiros do gabinete (4). Além do ordenamento dos partidos de acordo com o seu nível de centralização, a tabela 3.6 traz informações sobre a porcentagem de recursos ${ }^{37}$ aprovados no orçamento (LOA) que cada partido controlava no momento da formação do gabinete, e a porcentagem de controle recebido por cada um dos partidos ordenados. Se a hipótese - a de que partidos com mais recursos para a implementação de políticas são mais controlados pelos seus parceiros do gabinete - levantada for verdadeira, devese esperar observar uma relação diretamente proporcional entre a quantidade de recursos para policy controlada por cada partido e a porcentagem de controle recebida (o grau de centralidade).

É justamente esse o padrão verificado nas redes analisadas. Dos 15 gabinetes formados no Brasil entre 1995 e 2014, em apenas três deles (FHCI1, FHCI2 e

\footnotetext{
36 A operacionalização do cálculo para definir o grau de centralidade de cada ator na rede encontra-se no apêndice $\mathbf{C}$ deste trabalho.

37 Recursos correspondentes à soma dos recursos do Executivo que um partido controla. Se forem delegados para um partido $\mathrm{X}$ os ministérios da Educação e Meio Ambiente, e essas pastas corresponderem a, respectivamente, $7 \%$ e $4 \%$ dos recursos do governo aprovados na LOA, considero que esse partido possui $11 \%$ de recursos para policy.
} 
LULAI4), o partido formador e o seu principal parceiro não receberam a maior porcentagem de controle horizontal. Isto é, em $86 \%$ dos gabinetes as redes de controle mútuo se formam a partir do objetivo de monitorar os partidos que possuem mais recursos para implementar políticas. Dito de forma mais clara, o controle intragabinete não segue um padrão aleatório, os partidos monitoram seus parceiros de gabinete que controlam mais recursos para políticas públicas. Isso explica por que o partido formador e o seu principal parceiro de governo receberam, em média, $82 \%$ do monitoramento observado em todas as redes de controle analisadas. A intensidade do monitoramento recebido pelos partidos é uma função diretamente proporcional ao volume de recursos delegados a esses atores.

No caso dos gabinetes formados durante os dois mandatos do presidente FHC, em dois (FHCI2 e FHCII2) dos quatro gabinetes formados, o principal parceiro foi o $\mathrm{PTB}^{38}$. Nos outros dois (FHCII1 e FHCII2), PFL e PMDB foram, respectivamente, os parceiros principais do PSDB, o partido formador do gabinete. Nos dois mandatos do presidente LULA e no primeiro mandato da presidenta DILMA, houve apenas dois principais parceiros. Nos quatro primeiros (LULAI1, LULAI2, LULAI3 e LULAI4) gabinetes formados no período LULA, o Partido Liberal (PL), partido do então vicepresidente da República José Alencar, assumiu o papel de principal parceiro do governo.

Depois disso, em todos os gabinetes formados no período LULA e DILMA, o papel de principal parceiro foi ocupado pelo PMDB. Como observa Figueiredo (2007), embora o PMDB tenha sido integrado ao governo ainda na coalizão LULAI2 (2004), num primeiro instante, não houve entre os integrantes do partido consenso acerca do espaço que a legenda deveria ocupar no governo. Esses conflitos foram sendo paulatinamente dissolvidos e o número de áreas delegadas para esse parceiro tornou-se progressivamente maior. O processo de ratificação desse movimento se deu através do escândalo do "mensalão", momento de grande desgaste político do presidente LULA, que demandou a reconfiguração do pacto político de sustentação do governo (Pereira; Power; Raile, 2009). Esse novo pacto envolveu a transferência de recursos do até então principal parceiro de gabinete, PL, para as mãos do PMDB.

\footnotetext{
${ }^{38}$ Por ter seus recursos contingenciados com gastos previdenciários obrigatórios, o Ministério da Previdência Social - delegado ao PFL neste período - não foi considerado como uma área com recursos para policy. Por essa razão, em dois dos quatro gabinetes formados durante os dois mandados do presidente FHC, o PTB - e não o PFL - foi considerado o principal parceiro do partido formador do gabinete.
} 
A relação entre intensidade de controle recebido e volume de recursos torna-se ainda mais evidente quando consideramos a saliência das áreas de policy que os partidos centralizados na rede coordenam. Utilizo como proxy de saliência a capacidade alocativa das áreas ministeriais. Em termos operacionais, o grau de saliência ministerial é determinado pela fração dos recursos do orçamento federal de que cada área dispõe para a implementação de políticas públicas. Tendo como referência os valores presentes na Lei Orçamentaria Anual (LOA), se uma área $X$ recebe 5\% dos recursos da união e outra área Y recebe 2\%, assumo que a área X é mais saliente.

Foram consideradas apenas as áreas ministeriais com recurso igual ou superior a $0,50 \%$ do orçamento federal, capitaneadas pelo partido formador e o seu principal parceiro em cada gabinete ${ }^{39}$. Existe uma relação clara e inequívoca entre o grau de centralidade na rede e as áreas de policy controladas por estes atores. Como é de se esperar de qualquer governo, o partido formador concentra em suas mãos os ministérios mais salientes. Áreas como Fazenda, Planejamento e Educação dificilmente são delegadas para os parceiros do gabinete. Todavia, este cálculo varia de acordo com o portfólio de políticas do Executivo, da quantidade de partidos que integram o gabinete e o tipo de preferência destes.

Nos gabinetes constituídos nos dois mandatos do presidente FHC, existe uma clara concentração de recursos no partido formador. Entre 1995 e 2002, apenas as áreas ${ }^{40}$ da agricultura, trabalho, defesa, transportes e integração nacional foram delegadas para outros parceiros do gabinete. As demais, não por coincidência as mais salientes, sempre permaneceram sob o controle do partido do presidente. Nos governos LULA e DILMA, dado o grau de dispersão ideológica e número de partidos no governo, o nível de concentração do partido formador é menor. Gabinetes grandes suscitam a maior partilha dos recursos para a implementação de políticas públicas.

\footnotetext{
39 As áreas ministeriais controladas pelo partido formador e o principal parceiro da coalizão podem ser consultadas no apêndice D (tabela D.1) deste trabalho.

40 Considero os ministros sem filiação partidária sempre como sendo da cota do partido formador. Assumo que, embora esses ministros também possam ter vínculos partidários, as escolhas integram a cota pessoal de escolha do chefe do Executivo (Presidente).
} 
Tabela 3.6. Posição dos atores nas redes de controle horizontal (FHC, LULA, DILMA).

\begin{tabular}{|c|c|c|c|c|c|c|c|c|c|c|c|c|}
\hline & \multicolumn{3}{|c|}{ FHCI1 } & \multicolumn{3}{|c|}{ FHCI2 } & \multicolumn{3}{|c|}{ FHCII1 } & \multicolumn{3}{|c|}{ FHCII2 } \\
\hline Ranking & Partido & $\%$ Recursos & $\%$ Controle & Partido & $\%$ Recursos & $\%$ Controle & Partido & $\%$ Recursos & $\%$ Controle & Partido & $\%$ Recursos & $\%$ Controle \\
\hline 1 & PFL & 0,62 & 52,38 & PSDB & 13,21 & 56,25 & PSDB & 8,26 & 63,27 & PSDB & 18,46 & 75 \\
\hline 2 & PSDB & 11,96 & 38,10 & PFL & 0,65 & 20,31 & PFL & 3,53 & 22,45 & PMDB & 2,42 & 12,5 \\
\hline 3 & PMDB & 2,06 & 9,52 & PMDB & 2,17 & 12,50 & PMDB & 1,87 & 10,20 & PPB & 0,8 & 12,5 \\
\hline \multirow[t]{2}{*}{4} & РTB & 3,79 & 4,76 & РTB & 4,56 & 4,69 & PPB & 2,45 & 2,04 & & & \\
\hline & \multicolumn{3}{|c|}{ LULAI1 } & \multicolumn{3}{|c|}{ LULAI2 } & \multicolumn{3}{|c|}{ LULAI3 } & \multicolumn{3}{|c|}{ LULAI4 } \\
\hline Ranking & Partido & $\%$ Recursos & $\%$ Controle & Partido & $\%$ Recursos & $\%$ Controle & Partido & $\%$ Recursos & $\%$ Controle & Partido & $\%$ Recursos & $\%$ Controle \\
\hline 1 & PT & 12,02 & 69,70 & PT & 8,1 & 82,81 & PT & 9,14 & 85,71 & PT & 9,18 & 73,33 \\
\hline 2 & PL & 1,1 & 9,09 & PL & 2,47 & 9,38 & PL & 2,01 & 7,14 & PMDB & 0,23 & 16,67 \\
\hline 3 & PDT & 0,2 & 4,55 & РTB & 0,03 & 6,25 & PMDB & 0,23 & 7,14 & PL & 2,01 & 10 \\
\hline \multirow[t]{2}{*}{4} & PV & 0,04 & 4,55 & PMDB & 0,14 & 1,56 & & & & & & \\
\hline & \multicolumn{3}{|c|}{ LULAI5 } & \multicolumn{3}{|c|}{ LULAII1 } & \multicolumn{3}{|c|}{ LULAII2 } & \multicolumn{3}{|c|}{ LULAII3 } \\
\hline Ranking & Partido & $\%$ Recursos & $\%$ Controle & Partido & $\%$ Recursos & $\%$ Controle & Partido & $\%$ Recursos & $\%$ Controle & Partido & $\%$ Recursos & $\%$ Controle \\
\hline 1 & PT & 6,08 & 65,22 & PT & 6,01 & 56,25 & PT & 6,06 & 61,64 & PT & 8,55 & 43,52 \\
\hline 2 & PMDB & 5,09 & 20,29 & PMDB & 6,72 & 12,5 & PMDB & 6,72 & 28,77 & PMDB & 8,34 & 43,52 \\
\hline 3 & PSB & 0,2 & 7,25 & PR & 0,57 & 6,25 & PR & 0,57 & 5,48 & PR & 0,81 & 11,11 \\
\hline \multirow[t]{2}{*}{4} & PL & 0,57 & 2,90 & PSB & 0,11 & 6,25 & $\mathrm{PP}$ & 0,17 & 2,74 & PP & 0,64 & 0,93 \\
\hline & \multicolumn{3}{|c|}{ DILMAI1 } & \multicolumn{3}{|c|}{ DILMAI2 } & \multicolumn{3}{|c|}{ DILMAI3 } & & & \\
\hline Ranking & Partido & $\%$ Recursos & $\%$ Controle & Partido & $\%$ Recursos & $\%$ Controle & Partido & $\%$ Recursos & $\%$ Controle & & & \\
\hline 1 & PT & 13,05 & 81,82 & PT & 13,64 & 66,67 & PT & 15,03 & 77,57 & & & \\
\hline 2 & PMDB & 4,2 & 6,49 & PMDB & 3,98 & 21,33 & PMDB & 4,67 & 14,95 & & & \\
\hline 3 & PSB & 0,28 & 3,90 & PR & 1,04 & 6,67 & PP & 1,18 & 4,67 & & & \\
\hline 4 & PP & 1,12 & 1,30 & PP & 1,02 & 2,67 & PDT & 2,15 & 0,93 & & & \\
\hline
\end{tabular}


Ainda assim, algumas áreas caras à agenda de reformas dos governos petistas, como educação, fazenda, justiça, desenvolvimento social, desenvolvimento agrário, e ciência e tecnologia, sempre estiveram sob o controle do partido formador. Contribuiu para uma tendência permanente de desconcentração de recursos, o movimento de integração ao governo de um parceiro político da envergadura do PMDB. Várias áreas ministeriais que até o meio do primeiro mandato do presidente LULA estiveram sob o controle do partido formador do gabinete, o PT, foram transferidas para o PMDB. Esse processo não apenas dotou este partido de maior capacidade de implementar políticas, como também criou fortes incentivos para que os parceiros do gabinete transferissem para ele parte dos fluxos de controle.

Apresento na tabela 3.7 o teste bivariado entre o grau de centralidade dos atores na rede e o volume de recursos do orçamento (LOA) recebido por cada um. Nesse exercício, a unidade de análise é o partido da coalizão que foi monitorado nas redes de controle horizontal ${ }^{41}$. O objetivo é analisar qual o impacto do volume de recursos que cada partido do gabinete possui para implementar políticas públicas sobre o seu grau de centralidade - volume de monitoramento recebido - nas redes de controle intra gabinete.

Tabela 3.7. Grau de centralidade nas redes de controle horizontal em função do volume de recursos do orçamento (LOA).

\begin{tabular}{ccccc}
\hline & $(\mathbf{I})$ & $(\mathbf{I I})$ & $(\mathbf{I I I})$ & $(\mathbf{I V})$ \\
Variáveis & Completo & FHC & LULA & DILMA \\
\hline \multirow{2}{*}{ \% de recursos (LOA) } & $0.497 * * *$ & $0.334 * * *$ & $0.655^{* * *}$ & $0.563 * * *$ \\
& $(0.0455)$ & $(0.0619)$ & $(0.0743)$ & $(0.0418)$ \\
Constante & $0.401^{*}$ & 0.910 & 0.241 & $-0.0495^{*}$ \\
& $(0.208)$ & $(0.635)$ & $(0.150)$ & $(0.246)$ \\
\hline $\mathbf{N}$ & 159 & 35 & 58 & 66 \\
$\mathbf{R}^{2}$ & 0.69 & 0.55 & 0.76 & 0.95 \\
\hline
\end{tabular}

Erro padrão robusto entre parênteses $* * * \mathrm{p}<0.01, * * \mathrm{p}<0.05, * \mathrm{p}<0.1$

Os testes bivariados realizados a partir de modelos Ordinary Least Squares (OLS) evidenciam a forte correlação entre as duas dimensões. A cada acréscimo de $1 \%$

\footnotetext{
41 Nesta análise são considerados apenas os partidos que receberam controle pelo menos uma vez, exclusive os partidos que apenas realizaram controle sobre algum ator das redes constituídas.
} 
na parcela de recursos do orçamento que cada partido detém, observa-se um aumento de 0.50 (completo), em média, numa escala de centralidade que varia entre 0 e 1 . O efeito observado é maior no governo LULA (0.65) e menor no governo FHC (0.33). Os altos valores do $\mathrm{R}^{2}$ indicam a grande capacidade explicativa da variável utilizada como preditora do grau de centralidade nas redes.

Em suma, o que explica o grau de centralidade dos partidos nas redes de controle horizontal do gabinete de governo é a quantidade de recursos para executar políticas que os atores acessam. Isso explica por que o partido formador recebe sempre maior volume de controle nas redes, e por que o principal partido parceiro do chefe de governo tem suas ações mais escrutinadas quando comparado aos outros parceiros do gabinete.

As evidências apresentadas nesta seção indicam que os partidos não estão preocupados apenas com os cargos que eles podem ocupar e/ou lotear nas pastas ministeriais que recebem. Os partidos do gabinete sempre procuram influenciar os resultados das políticas públicas que lhes interessam; mesmo aquelas sob o controle de outros partidos.

\subsection{Análise do conteúdo das ações de controle: quais são as áreas e os temas controlados pelos partidos da coalizão?}

Nas seções anteriores deste capítulo, demonstrei que a presença de múltiplas preferências no gabinete de governo está positivamente correlacionada com as ações de controle de políticas públicas implementadas pelos partidos da coalizão. O objetivo desta seção é analisar o conteúdo das ações de controle que os partidos realizam via requerimento de informação. Essa análise se dará a partir da consideração das áreas ministeriais às quais se dirigem as ações de controle (Áreas), a temática relacionada às ações de controle (Temática) e a instância (local, regional, ou nacional) de implementação das ações de controle (Nível de Agregação). Para tanto, foram analisados os 817 requerimentos de informação amostrados e utilizados na construção das redes de controle horizontal apresentadas na seção 3.3 deste capítulo.

\section{1. Áreas}

O gráfico 3.2 informa quais as áreas ministeriais foram alvo de controle dos partidos e a proporção de controle, em cada governo analisado. A constatação mais evidente é que o número de áreas ministeriais controladas nos governos LULA e DILMA é consideravelmente maior do que no governo FHC. Isso se deve, em primeiro 
lugar, ao maior número de ministérios existentes nos governos petistas ${ }^{42}$. A criação de pastas ministeriais para tratar de temáticas específicas institucionaliza a possibilidade de controle em um número maior de áreas. Em segundo lugar, esse fato se relaciona com o maior número de atores que integram o governo e se interessam por áreas específicas de políticas. A fragmentação do sistema partidário brasileiro, que dificulta a formação de maiorias legislativas por um único partido, e, portanto, aumenta a probabilidade da composição de coalizões grandes e heterogêneas ${ }^{43}$, acaba por induzir um cenário comum em sistemas multipartidários: a competição por influência nas diversas áreas de policy.

\footnotetext{
${ }^{42}$ Como mostra Batista (2014), durante dos dois governos do presidente FHC, foram criados os ministérios da Defesa - em substituição aos ministérios da Aeronáutica, Exército e Marinha - e da Integração Nacional. Durante os mandatos do presidente LULA, além da manutenção destas pastas recém-criadas, foram constituídos os ministérios das Cidades e do Desenvolvimento Social. A presidenta Dilma, por seu turno, manteve essas pastas e criou o Ministério da Pesca e Aquicultura. Para mais informações sobre a criação de órgãos no gabinete e na estrutura da presidência ver Inácio (2012), Lameirão, (2015) e Vieira (2013).

${ }^{43}$ De acordo com o modelo proposto por Cheibub et al (2004), dada a inclinação dos partidos para executar políticas, só existe incentivo para que uma coalizão de governo seja constituída quando as preferências do partido formador se situam longe do partido que lhe está mais próximo no espectro ideológico. Isto é, se o partido do presidente consegue formar uma maioria que lhe assegura a implementação de sua agenda com partidos de preferências próximas, não faz sentido delegar para outros as áreas de policy do Executivo. É preferível que partido formador opte por arcar com os custos e benefícios de todas as políticas implementadas pelo governo. No caso brasileiro, em virtude da alta fragmentação partidária propiciada pelas regras do sistema eleitoral, a construção de maiorias na arena parlamentar passa pela necessidade de se aliar com partidos de preferências extremas. Nesse contexto, o PMDB tem desempenhado o papel de fiel da balança, sendo o partido pivotal responsável por viabilizar coalizões majoritárias desde o governo Itamar Franco (Melo; Nunes, 2009).
} 
Gráfico 3.2. Áreas ministeriais monitoradas pelos partidos via requerimento de informação (RIC), nos governos FHC, LULA e DILMA (1995 -2014).

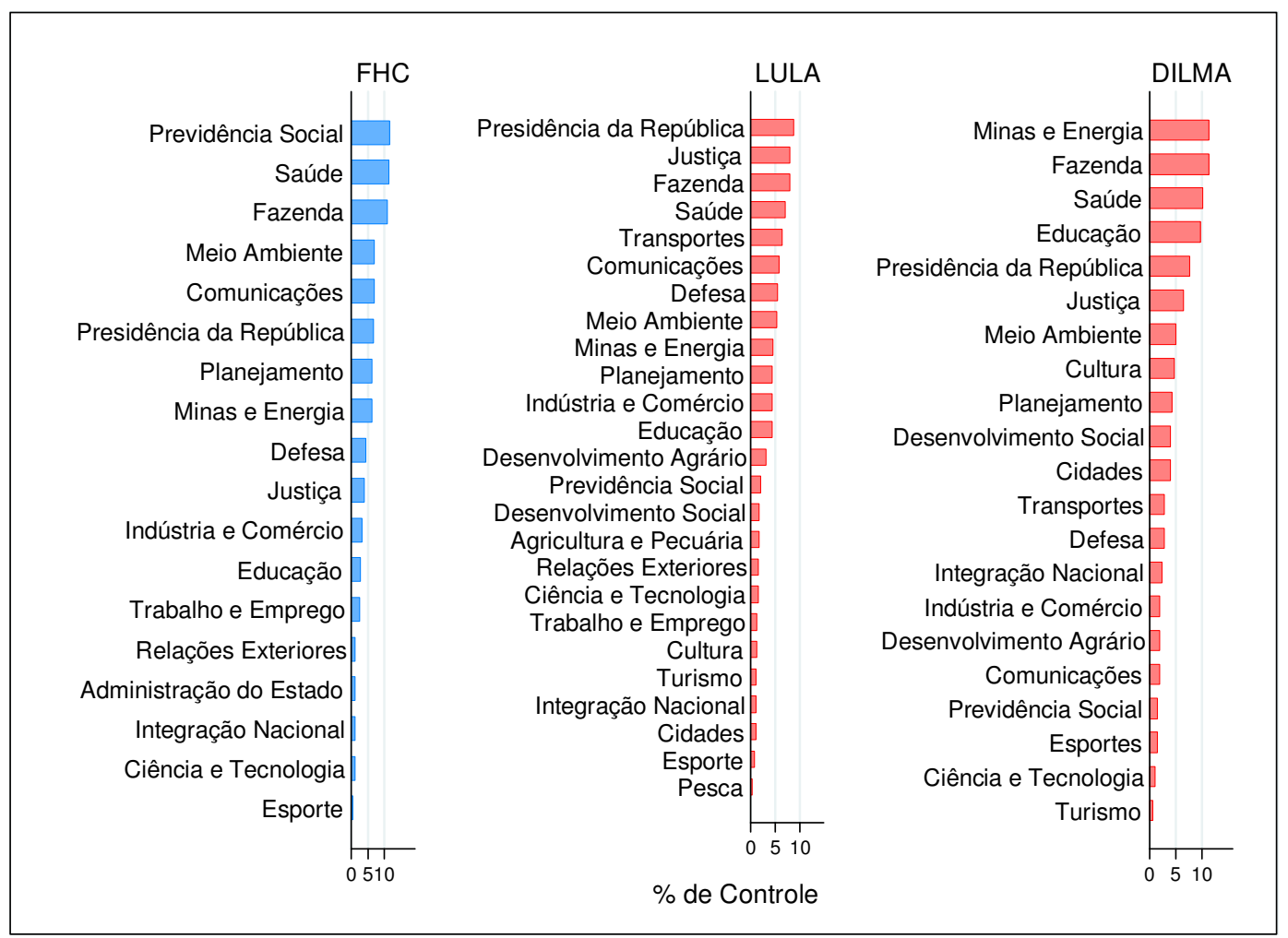

Fonte: Elaborado pelo autor a partir dos dados da Câmara dos Deputados

Existe grande variação na posição que cada área ocupa nos três governos, mas verifica-se mais estabilidade das pastas ministeriais que recebem maior proporção de controle. Os Ministérios da Saúde e Fazenda, nos três governos, sempre apresentam mais de $8 \%$ das ações de controle. Os Ministérios da Justiça, Comunicações, e Meio Ambiente foram também áreas constantemente monitoradas nos três governos. Existem, ainda, áreas que apresentaram proeminência em períodos específicos. Durantes os dois mandatos do governo FHC a área da Previdência Social foi sistematicamente monitorada. Tal controle é um indício dos conflitos já existentes em torno dessa política e que acabaram culminando numa reforma da previdência no primeiro mandato do presidente LULA (Melo; Anastasia, 2005). 
Tabela 3.8. Participação dos partidos da coalizão nas ações de controle por área ministerial e governo.

\begin{tabular}{|c|c|c|c|c|c|c|c|c|c|c|c|c|}
\hline Área & N. FHC & $\%$ FHC & FHC CEC & FHC CEO & N.LULA & \% LULA & LULA CEC & LULA CEO & N.DILMA & \% DILMA & DILMA CEC & DILMA CEO \\
\hline Defesa & 8 & 4,62 & 0,01 & 0,38 & 23 & 5,56 & 0,20 & 0,10 & 8 & 3,02 & 0,20 & 0,13 \\
\hline Educação & 3 & 3,09 & 0,10 & 0,12 & 18 & 4,35 & 0,20 & 0,25 & 25 & 9,65 & 0,20 & 0,23 \\
\hline Fazenda & 16 & 11,18 & 0,30 & 0,25 & 34 & 8,23 & 0,33 & 0,16 & 29 & 11,19 & 0,10 & 0,18 \\
\hline Justiça & 6 & 4,19 & 0,10 & 0,23 & 34 & 8,23 & 0,40 & 0,13 & 17 & 6,56 & 0,30 & 0,20 \\
\hline Meio Ambiente & 10 & 6,99 & 0,23 & 0,23 & 22 & 5,32 & 0,30 & 0,20 & 13 & 5,01 & 0,10 & 0,16 \\
\hline Minas e Energia & 9 & 6,29 & 0,13 & 0,32 & 19 & 4,6 & 0,25 & 0,20 & 29 & 11,19 & 0,13 & 0,25 \\
\hline Planejamento & 9 & 6,29 & 0,25 & 0,18 & 18 & 4,35 & 0,13 & 0,13 & 11 & 4,24 & 0,24 & 0,23 \\
\hline Pres. da República & 11 & 6,69 & 0,10 & 0,29 & 37 & 8,95 & 0,18 & 0,13 & 20 & 7,72 & 0,18 & 0,21 \\
\hline Saúde & 15 & 11,48 & 0,50 & 0,20 & 30 & 8,26 & 0,29 & 0,27 & 26 & 10,03 & 0,29 & 0,18 \\
\hline Total & 87 & 60,82 & & & 235 & 56,85 & & & 178 & 68,61 & & \\
\hline
\end{tabular}

Fonte: Elaborado pelo autor a partir dos dados da Câmara dos Deputados 
No caso do governo LULA, a área de transportes aparece de forma destacada. Além de ser uma área de implementação de obras de infraestrutura - o que normalmente já desperta o interesse dos partidos da coalizão em virtude do volume de investimento envolvido -, durante o primeiro mandato do presidente LULA, essa área ministerial esteve envolvida no escândalo do "mensalão", produzindo um efeito catalisador das ações de controle. Por fim, durante o governo DILMA, a área da educação recebeu especial atenção dos parlamentares. Tal fato está relacionado com o aumento de recursos do orçamento federal para essa área ${ }^{44}$ e com a implementação de programas com alta capilaridade nos municípios brasileiros, caso do Programa Nacional de Acesso ao Ensino Técnico e Emprego (Pronatec).

A tabela 3.8 informa a proporção de ações de controle via requerimento de informação, nas nove áreas que receberam pelo menos $3 \%$ de controle nos governos analisados. Da mesma forma que na seção 3.3 deste capítulo, os indicadores $\mathrm{CEC}^{45} \mathrm{e}$ $\mathrm{CEO}^{46}$ foram utilizados para dimensionar a participação dos partidos da coalizão e da oposição no monitoramento das políticas públicas.

Durante o governo FHC, o controle exercido pelos partidos da coalizão foi mais efetivo nas áreas da Saúde (0,50), Fazenda (0,30), Meio Ambiente $(0,23)$ e Planejamento $(0,25)$. No governo LULA, este número foi ainda maior. A coalizão controlou de forma mais efetiva as áreas da Saúde (0,29), Fazenda (0,33), Justiça $(0,40)$, Meio Ambiente $(0,30)$, Minas e Energia $(0,25)$ e os órgãos diretamente ligados à Presidência da República $(0,18)$. No caso do governo DILMA, o controle dos partidos da coalizão foi mais efetivo nas pastas da Saúde $(0,29)$, Planejamento $(0,24)$, Justiça $(0,30)$, e Defesa $(0,20)$.

O fato a ser notado é que coalizão e oposição utilizam os requerimentos de informação de maneiras distintas. Os partidos da coalizão direcionam seus esforços para monitorar as políticas nas áreas com grande volume de recursos para implementação de políticas, como no caso da Saúde, Justiça e Minas e Energia, ou nas áreas com grande influência sobre as políticas do Executivo de maneira geral, como a Fazenda e o Planejamento. A oposição, por seu turno, monitora prioritariamente os órgãos da Presidência da República, o Ministério da Defesa e a educação. Embora esta última área

\footnotetext{
${ }^{44}$ A média de recursos do orçamento federal para a educação durante os dois mandatos do presidente LULA foi de $11,08 \%$ da LOA. No primeiro mandato da presidenta DILMA, a média foi de $15,14 \%$, um aumento de mais de quatro pontos percentuais.

${ }^{45}$ Ver nota 19.

${ }^{46}$ Ver nota 20.
} 
seja extremamente saliente, o controle realizado pela oposição sempre foi mais efetivo, ainda que nos três governos a diferença na participação dos dois grupos seja relativamente pequena.

\section{Temática}

Para a análise da segunda dimensão, as ações de controle de políticas públicas foram agrupadas em 11 categorias $^{47}$, derivadas de análise qualitativa e quantitativa de texto dos 817 requerimentos de informação amostrados. O gráfico $\mathbf{3 . 3}$ apresenta a proporção de controle em cada uma das categorias operacionalizadas, nos governos FHC, LULA e DILMA.

Gráfico 3.3. Tema das ações de controle realizadas pelos partidos via requerimento de informação (RIC), nos governos FHC, LULA e DILMA (1995 - 2014).

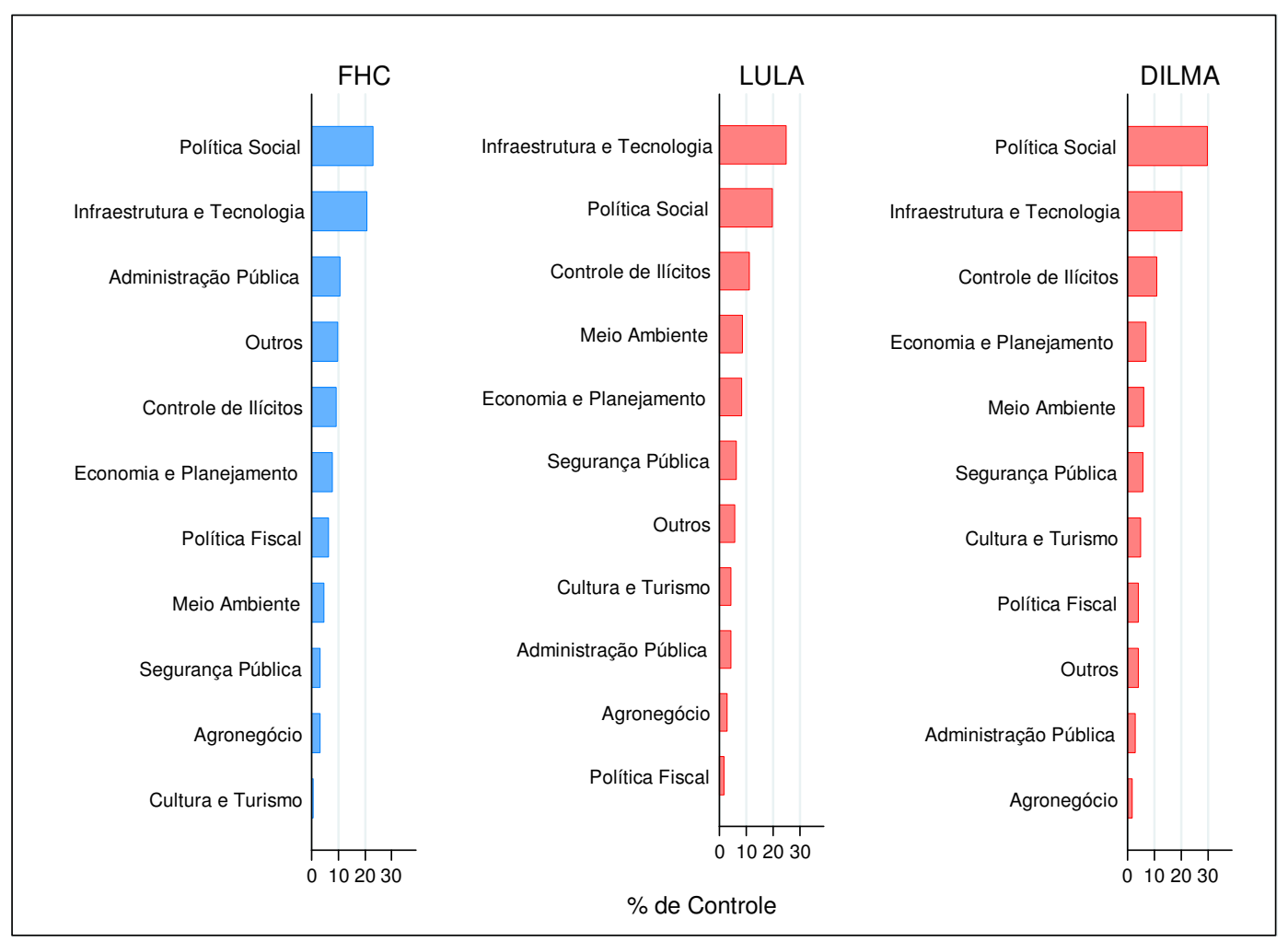

Fonte: Elaborado pelo autor a partir dos dados da Câmara dos Deputados

Nos três governos analisados, os temas relacionados à Política Social e Infraestrutura aparecem como os mais controlados pelos partidos. Outros temas como Economia e Planejamento, Segurança Pública e Meio Ambiente são também visados

\footnotetext{
47 No apêndice $\mathbf{E}$ deste trabalho pode ser conferido o teor dos requerimentos de informação (RIC) utilizados para compor cada categoria.
} 
pelos parlamentares responsáveis pelas ações de controle. $\mathrm{O}$ argumento de que as prerrogativas de controle horizontal do Poder Legislativo são utilizadas principalmente para controle e correção de ilicitudes cometidas pelos agentes do Executivo não se confirma empiricamente.

Nos governos FHC, LULA e DILMA, a proporção de ações de controle relacionadas a controle de ilícitos nunca superou 11,5\%. Em outra direção, se somarmos as categorias relacionadas ao controle de implementação de policy - ou seja, excluindo Administração Pública, Controle de Ilícitos e Sem Classificação -, a proporção é sempre superior a $80 \%$. Essa proporção é menor no governo FHC $(80,42)$ e maior no governo DILMA $(84,17)$. Isto é, na grande maioria dos casos os partidos utilizam os requerimentos de informação para monitorar o processo de implementação de políticas públicas.

A questão que emerge, portanto, é: os partidos da coalizão e da oposição se ocupam dos mesmos temas nas ações de controle? A tabela 3.9 informa o controle efetivo da coalizão (CEC) e o controle efetivo da oposição (CEO), em cada temática, nos governos FHC, LULA e DILMA.

No governo FHC, o controle da coalizão foi mais efetivo nos temas relacionados ao Agronegócio $(0,20)$, Infraestrutura e Tecnologia (0,38), Política Fiscal $(0,30)$ e Política Social $(0,53)$. Nos dois mandatos do presidente LULA, Infraestrutura e Tecnologia (0,56), Meio Ambiente $(0,28)$, Política Fiscal $(0,30)$ e Política Social $(0,56)$ foram os temas mais efetivamente monitorados pelos partidos da coalizão. Enquanto isso, no primeiro mandato da presidenta DILMA, o controle da coalizão foi mais efetivo nos temas relacionados ao Agronegócio $(0,15)$, Cultura e Turismo $(0,25)$, Economia e Planejamento $(0,20)$, Infraestrutura e Tecnologia $(0,33)$, Política Fiscal $(0,15)$ e Política Social $(0,48)$. 
Tabela 3.9. Participação dos partidos da coalizão nas ações de controle por temática e governo.

\begin{tabular}{|c|c|c|c|c|c|c|c|c|c|c|c|c|}
\hline Natureza & FHC & $\%$ FHC & FHC CEC & FHC CEO & LULA & \% LULA & LULA CEC & LULA CEO & DILMA & \% DILMA & DILMA CEC & DILMA CEO \\
\hline Administração Pública & 15 & 10,49 & 0,10 & 0,33 & 18 & 4,33 & 0,10 & 0,25 & 7 & 2,70 & 0,10 & 0,10 \\
\hline Agronegócio & 5 & 3,50 & 0,20 & 0,15 & 12 & 2,88 & 0,13 & 0,13 & 4 & 1,54 & 0,15 & 0,10 \\
\hline Controle de Ilícitos & 13 & 9,09 & 0,17 & 0,20 & 47 & 11,54 & 0,26 & 0,50 & 29 & 11,20 & 0,18 & 0,23 \\
\hline Cultura e Turismo & 1 & 0,70 & 0,02 & 0,10 & 18 & 4,33 & 0,13 & 0,28 & 13 & 5,02 & 0,25 & 0,10 \\
\hline Economia e Planejamento & 11 & 7,69 & 0,15 & 0,27 & 34 & 8,17 & 0,26 & 0,26 & 18 & 6,95 & 0,20 & 0,13 \\
\hline Infraestrutura e Tecnologia & 30 & 20,98 & 0,38 & 0,37 & 105 & 25,24 & 0,56 & 0,50 & 53 & 20,46 & 0,33 & 0,28 \\
\hline Meio Ambiente & 7 & 4,90 & 0,10 & 0,17 & 37 & 8,89 & 0,28 & 0,23 & 16 & 6,18 & 0,10 & 0,23 \\
\hline Política Fiscal & 9 & 6,29 & 0,30 & 0,20 & 7 & 1,68 & 0,30 & 0,13 & 11 & 4,25 & 0,15 & 0,11 \\
\hline Política Social & 33 & 23,08 & 0,53 & 0,28 & 82 & 19,71 & 0,56 & 0,54 & 77 & 29,73 & 0,50 & 0,48 \\
\hline Segurança Pública & 5 & 3,50 & 0,10 & 0,15 & 26 & 6,25 & 0,23 & 0,25 & 15 & 5,79 & 0,10 & 0,26 \\
\hline Outros & 14 & 9,79 & 0,10 & 0,28 & 23 & 5,53 & 0,21 & 0,16 & 11 & 4,25 & 0,10 & 0,18 \\
\hline Sem Classificação & 0 & 0,00 & 0 & 0 & 6 & 1,44 & 0,10 & 0,13 & 5 & 1,93 & 0,50 & 0,00 \\
\hline Total & 143 & 100,00 & & & 415 & 100,00 & & & 259 & 100,00 & & \\
\hline
\end{tabular}


Há, assim, uma clara divisão entre as temáticas de que se ocupam os partidos da coalizão e da oposição. Nos governos FHC, LULA e DILMA, o controle realizado pelos partidos da coalizão sempre foi mais efetivo nos temas de Política Social e Infraestrutura e Tecnologia. Em outra direção, nos três governos, os temas relacionados à Administração Pública e ao Controle de Ilícitos receberam mais atenção dos partidos da oposição.

Nas redes de controle horizontal não existe, portanto, nenhuma evidência de que os partidos da coalizão são indiferentes às diversas áreas de políticas do Executivo. Além de coordenar as áreas ministeriais delegadas pelo presidente, os partidos se ocupam de vários outros temas de políticas, sempre privilegiando os temas mais salientes relacionados às políticas sociais e infraestrutura.

\section{Nível de Agregação}

A terceira e última dimensão de análise de conteúdo dos requerimentos de informação diz respeito ao nível de agregação (Individual, Local, Regional, Nacional e Setorial) do conteúdo das ações de controle. Utilizo a categorização proposta por Amorim Neto e Santos (2003) para investigar o conteúdo da produção legislativa dos parlamentares da Câmara dos Deputados. De modo distinto, no presente trabalho, as categorias foram utilizadas para agregar as ações de controle de acordo com os objetivos descritos pelos parlamentares na ementa de cada um dos 817 requerimentos de informação.

Se a ação de controle de um parlamentar tem por objetivo controlar uma dada política pública no nível municipal, o requerimento de informação se enquadra na categoria "Local". Se a ação de controle do parlamentar objetiva monitorar um dado programa do governo federal sem, no entanto, especificar a sua aplicação em alguma região ou município, o requerimento de informação se enquadra na categoria "Nacional". Os requerimentos de informação relacionados ao controle de indivíduos e grupos específicos da sociedade enquadram-se, respectivamente, nas categorias "Individual" e "Setorial" 48.

O gráfico 3.4 informa a proporção de controle em cada uma das categorias, nos governos FHC, LULA e DILMA. A primeira evidência que este o gráfico fornece é que,

48 No apêndice $\mathbf{F}$ deste trabalho pode ser analisado o teor dos requerimentos de informação (RIC) utilizados para compor cada categoria. 
nos três períodos, o número de ações de controle destinado a controlar a ação isolada de agentes de implementação de políticas públicas é muito baixo - em média, 5,16\% dos requerimentos de informação se enquadram nessa categoria. Os partidos monitoram prioritariamente as políticas no nível nacional.

Gráfico 3.4. Nível de agregação das ações de controle realizadas pelos partidos via requerimento de informação (RIC), nos governos FHC, LULA e DILMA (1995- 2014).

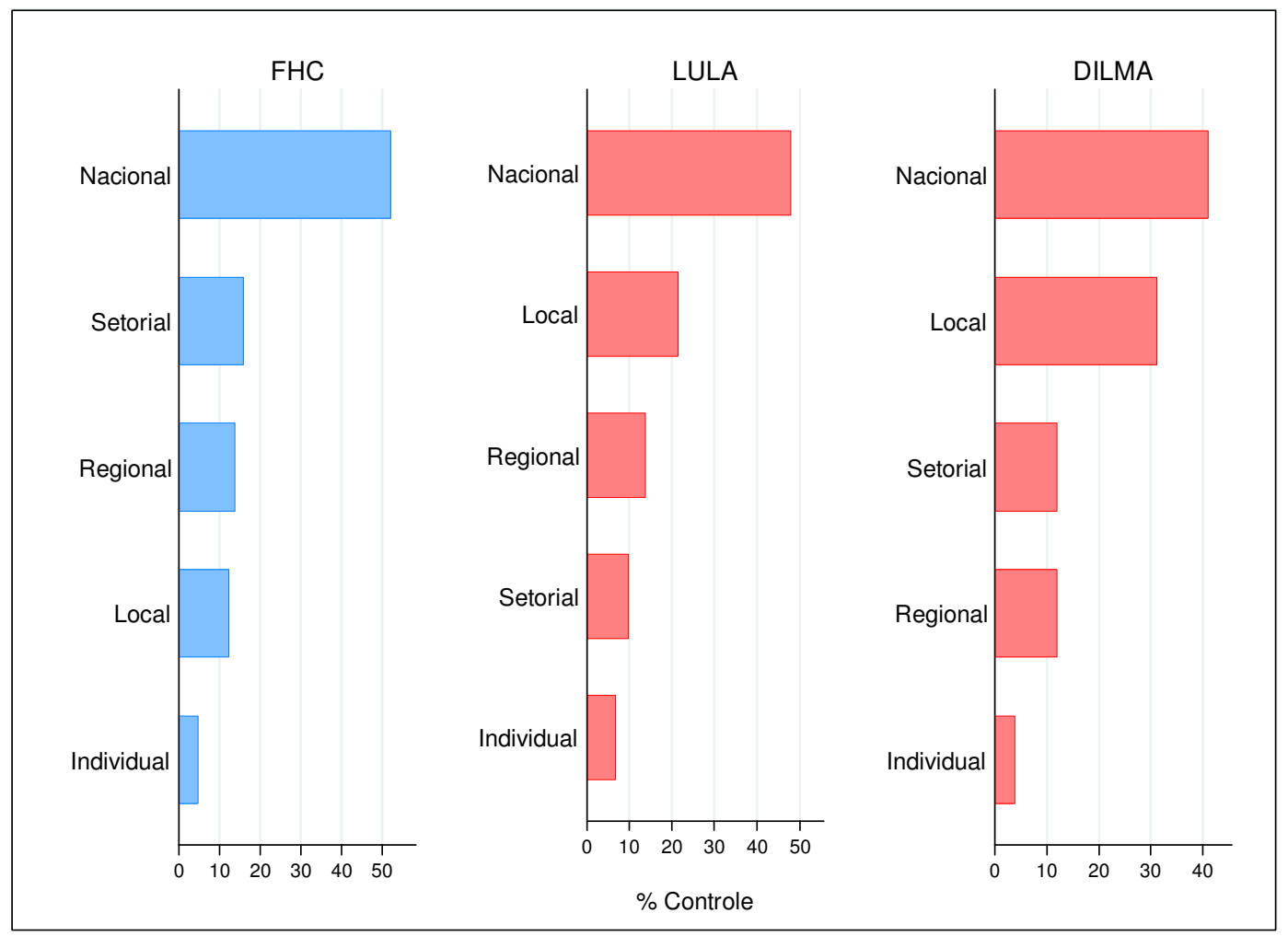

Fonte: Elaborado pelo autor a partir dos dados da Câmara dos Deputados

É possível notar, ainda, que a proporção de ações de controle enquadradas na categoria "Local" apresenta tendência de crescimento no tempo. No governo FHC, essa categoria concentra 12,6\% das ações de controle. A mesma categoria concentra 21,63\% e 31,27\% nos governos LULA e DILMA, respectivamente. Esse, entretanto, não é um indício da ação particularista dos partidos, mas, em outra direção, uma evidência da influência que os partidos da coalizão tentam exercer sobre as políticas públicas em todos os seus níveis de implementação. Os dados apresentados na tabela $\mathbf{3 . 1 0}$ são sintomáticos a esse respeito. 
Tabela 3.10. Participação dos partidos da coalizão nas ações de controle por nível e governo.

\begin{tabular}{|c|c|c|c|c|c|c|c|c|c|c|c|c|}
\hline Nível & FHC & $\%$ FHC & FHC CEC & FHC CEO & LULA & \% LULA & LULA CEC & LULA CEO & DILMA & \% DILMA & DILMA CEC & DILMA CEO \\
\hline Individual & 7 & 4,9 & 0,00 & 0,23 & 27 & 6,73 & 0,15 & 0,38 & 10 & 3,86 & 0,12 & 0,16 \\
\hline Local & 18 & 12,6 & 1,5 & 0,30 & 90 & 21,63 & 0,63 & 0,57 & 81 & 31,27 & 0,63 & 0,51 \\
\hline Regional & 20 & 14,0 & 0,20 & 0,70 & 57 & 13,70 & 0,36 & 0,31 & 31 & 11,97 & 0,20 & 0,19 \\
\hline Nacional & 75 & 52,4 & 0,65 & 0,49 & 200 & 48,08 & 0,72 & 0,63 & 106 & 40,93 & 0,56 & 0,36 \\
\hline Setorial & 23 & 16,1 & 0,20 & 0,42 & 41 & 9,86 & 0,21 & 0,28 & 31 & 11,97 & 0,20 & 0,25 \\
\hline Total & 143 & 100,0 & & & 415 & 100,0 & & & 259 & 100,0 & & \\
\hline
\end{tabular}

Fonte: Elaborado pelo autor a partir dos dados da Câmara dos Deputados 
Durante os dois mandatos do presidente FHC, a coalizão foi mais efetiva nos níveis Local $(1,5)$ e Nacional $(0,65)$. No governo LULA, a coalizão dominou as ações de controle nos níveis Local $(0,63)$, Regional $(0,36)$ e Nacional $(0,72)$. No primeiro mandato da presidenta DILMA, da mesma forma, vis-à-vis aos partidos da oposição, a coalizão foi mais efetiva nos níveis Local $(0,63)$, Regional $(0,20)$ e Nacional $(0,56)$.

Em suma, os partidos da coalizão exercem um controle mais efetivo nos níveis "Nacional", "Regional" e "Local", ao mesmo tempo em que a oposição se concentra nas ações de controle do tipo "Individual" e "Setorial". Enquanto os partidos da coalizão concentram seus esforços na tentativa de influenciar as políticas ao longo da cadeia de implementação, os partidos da oposição monitoram, preferencialmente, as ações individuais de agentes da burocracia do Executivo e as políticas ligadas a grupos setoriais específicos.

Todas as evidências empíricas apresentadas validam as hipóteses formuladas no início deste capítulo [seção 3.1]. As redes de controle horizontal, de fato, variam em função do grau de dispersão de preferências do gabinete de governo. Essa alta correlação é explicada pelo objetivo dos partidos de influenciar as políticas do Executivo. A distribuição de áreas ministeriais para muitos atores aumenta o risco de assimetria de informação e força os integrantes do gabinete a adotarem estratégias que possam lhes garantir acesso às políticas do seu interesse e que são implementadas por outros partidos da coalizão de governo. Como resultado, os partidos que possuem mais recursos para a implementação de políticas públicas são também aqueles atores que recebem o maior volume de controle - via requerimento de informação - de seus parceiros de governo.

Cabe destacar, ainda, que, embora os partidos que não integram o governo também monitorem as atividades do Executivo, a ocorrência de redes mais densas de controle horizontal está relacionada com as ações de controle apresentadas pelos partidos da coalizão. São estes os maiores responsáveis pelo monitoramento das áreas mais salientes como política social e infraestrutura, em todas os níveis de implementação das políticas.

No próximo capítulo, investigo se esse mesmo padrão pode ser verificado quando os parlamentares fazem uso de outros dois mecanismos de controle horizontal, qual sejam, as Propostas de Fiscalização e Controle (PFC) e os Projetos de Decreto Legislativo (PDC). 


\section{CAPÍTULO 4}

\section{Evidências alternativas de Controle horizontal em gabinetes multipartidários no Brasil}

No capítulo anterior, argumentei que os partidos da coalizão utilizam os requerimentos de informação como mecanismo de controle das políticas públicas implementadas por seus parceiros de governo. Neste capítulo, apresento evidências adicionais de que as ações de controle se intensificam em gabinetes heterogêneos - com preferências partidárias dispersas.

Para tanto, utilizo outro mecanismo de controle horizontal à disposição dos parlamentares brasileiros, a saber, a Proposta de Fiscalização e Controle (PFC). Embora não seja prescrita constitucionalmente como os requerimentos de informação (RIC), a PFC está prevista nos regimentos internos das duas Casas Legislativas ${ }^{49}$ e cumpre o mesmo objetivo de fiscalizar as ações empreendidas pelo Poder Executivo.

Assim como o requerimento de informação, trata-se de um instrumento de controle horizontal de baixo custo (Lemos, 2005a), que pode ser apresentado por qualquer parlamentar à comissão permanente cujo campo temático seja relacionado ao tema da proposta, ou à Comissão de Fiscalização Financeira e Controle, sobre qualquer tema, com fundamentação e indicação específica do ato a ser fiscalizado ${ }^{50}$ (Gomes, 2008).

No gráfico 4.1, pode ser visualizada a tendência do uso das propostas de fiscalização e controle pelos partidos da coalizão para controlar as ações dos parceiros de governo. Foram consideradas todas as 417 ações de controle apresentadas pelos parlamentares da Câmara dos Deputados entre 1995 e 2014. A linha vermelha é a variação da proporção de requerimentos de informação apresentados pelos partidos da coalizão, denominada "Taxa de Controle Horizontal no Gabinete" e representada no eixo (Y1). Os traços de cor verde representam os gabinetes de governo formados no Brasil no mesmo período. A extensão destes traços representa o grau de dispersão

\footnotetext{
${ }^{49}$ Artigo. 61 do regimento da Câmara dos Deputados e Artigo 102- B do Senado Federal.

${ }^{50}$ Como assevera Gomes (2008), "uma proposta de fiscalização e controle não pode ser apresentada na Comissão de Legislação Participativa, já que esta Comissão não possui função fiscalizatória, nem campo temático ou área de atuação" (p.44).
} 
ideológica, indicador do grau de heterogeneidade de preferências em cada gabinete ${ }^{51}$ (Y2).

Gráfico 4.1. Variação do número de Propostas de Fiscalização e Controle (PFC) em função do grau de heterogeneidade ideológica do gabinete de governo (1995-2014).

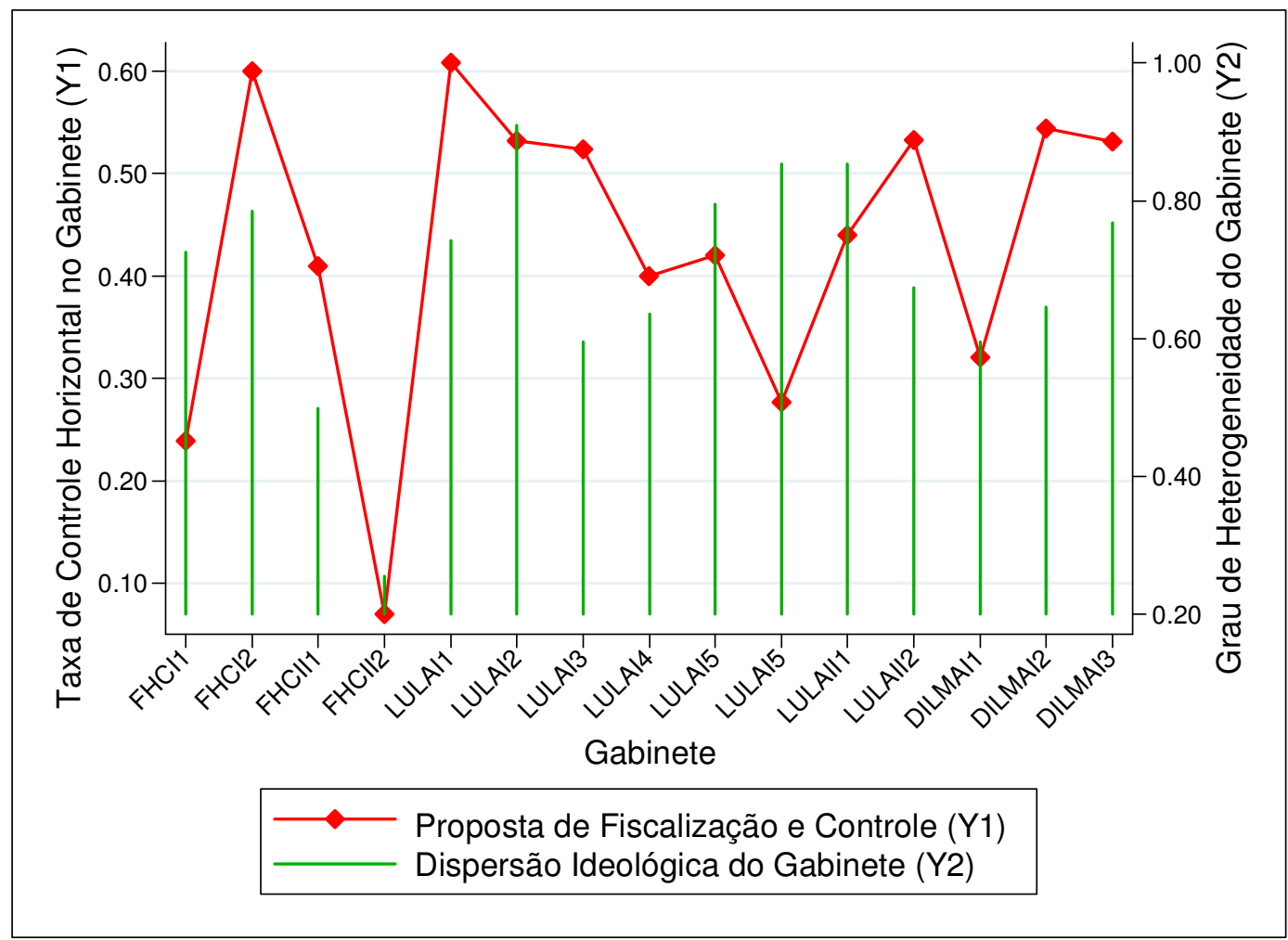

Fonte: Elaborado pelo autor a partir dos dados da Câmara dos Deputados

A análise no tempo dos eixos (Y1) e (Y2) evidencia a forte correlação entre a taxa de controle da burocracia ministerial e o grau de heterogeneidade dos gabinetes. Medido pelo coeficiente de Pearson, as duas linhas apresentam correlação de $0.76^{52}$ numa escala que varia entre 0 e 1 . Isso indica que, o mesmo padrão verificado no uso dos requerimentos de informação também é observado quando as PFC são consideradas: os partidos da coalizão intensificam o controle das áreas ministeriais capitaneadas por seus parceiros de governo quando o gabinete é composto por preferências mais dispersas e/ou extremas.

De forma análoga ao procedimento metodológico adotado para construir as redes de controle horizontal formadas a partir da utilização dos requerimentos de informação, neste capítulo, reconstituo as redes formadas nos governos FHC, LULA e

\footnotetext{
${ }^{51}$ Assim como na tabela 2.1, a heterogeneidade ideológica dos gabinetes foi calculada a partir dos dados presentes em Power \& Zucco (2009); Zucco \& Lauderdale (2011).

${ }^{52}$ No nível de $\mathrm{p}<0.01$.
} 
DILMA, por efeito da utilização das propostas de fiscalização e controle como mecanismo de monitoramento das políticas públicas.

Foram utilizadas para a construção das redes as 417 propostas de fiscalização e controle apresentadas entre 1995 e 2014. As redes são do tipo one mode $e^{53}$ e representam a relação entre dois partidos na fase de implementação de políticas públicas. Isto é, cada relação representa o controle de um partido X sobre uma dada ação de implementação de política pública de um partido W. Em virtude do menor número de ações de controle, as PFC não foram agrupadas por gabinete - como no caso dos requerimentos de informação -, mas por governo. As redes apresentadas nesta seção representam, assim, as relações de controle estabelecidas nos dois mandatos do governo FHC, nos dois mandatos do governo LULA e no primeiro mandato do governo DILMA.

53 Ver nota 26. 
Tabela 4.1. Descritivas das redes de controle horizontal (PFC).

\begin{tabular}{|c|c|c|c|c|c|c|c|c|c|c|}
\hline Gabinete & Duração & N. Atores & N. Relações & $\begin{array}{l}\text { N. Ações de } \\
\text { Controle }\end{array}$ & N. Coalizão & $\begin{array}{l}\text { Partidos } \\
\text { Coalizão }\end{array}$ & N. Oposição & $\begin{array}{l}\text { Partidos } \\
\text { Oposição }\end{array}$ & CEC & CEO \\
\hline FHC I & 1.459 & 13 & 26 & 66 & 26 & 5 & 40 & 8 & 0,52 & 0,50 \\
\hline FHC II & 1.459 & 9 & 23 & 72 & 36 & 4 & 36 & 4 & 0,90 & 0,90 \\
\hline LULA I & 1.456 & 13 & 22 & 60 & 21 & 10 & 39 & 3 & 0,21 & 1,30 \\
\hline LULA II & 1.458 & 12 & 23 & 100 & 68 & 8 & 32 & 4 & 0,85 & 0,80 \\
\hline DILMA I & 1.823 & 19 & 35 & 119 & 54 & 7 & 65 & 12 & 0,77 & 0,54 \\
\hline
\end{tabular}

Fonte: elaborada pelo autor a partir dos dados da Câmara dos Deputados 
A tabela 4.1 informa as descritivas das redes formadas nos três governos analisados. A constatação empírica mais básica é que o número médio de PFC aumentou no período analisado. No governo FHC, a média de ações de controle foi de 65,5, enquanto nos governo LULA e DILMA essa média foi de, respectivamente, 76 e 125. O aumento pode ser explicado pelo maior número de partidos da coalizão envolvidos nas ações de controle, ou seja, a maior densidade das redes de controle horizontal está relacionada com os conflitos inerentes à delegação em governos maiores e mais heterogêneos.

Esse argumento pode ser testificado através da análise dos dois indicadores $\mathrm{CEC}^{54}$ e $\mathrm{CEO}^{55}$ apresentados na tabela 4.1. Assim como nos usos anteriores neste trabalho, os dois indicadores cumprem o objetivo de ponderar a participação na rede dos partidos da coalizão e da oposição, pelo número de atores dos dois grupos que realizam ações de controle. Das cinco redes de controle horizontal construídas, os partidos da coalizão desempenharam um controle igual ou mais efetivo em quatro (80\%) delas. Com exceção da rede LULAI, período em que ocorreu o escândalo do "Mensalão" e houve intensa participação dos partidos da oposição na fiscalização das ações do Executivo, em todas as outras redes, foi predominante o uso dessa prerrogativa parlamentar enquanto ferramenta de controle e monitoramento de políticas públicas.

A representação gráfica das redes de controle horizontal é apresentada na figura 4.1. Como é possível visualizar, a maior densidade das redes constituídas nos governos LULA e DILMA é uma decorrência da maior participação dos partidos da coalizão no controle das políticas públicas. Isso não significa que a coalizão não tenha sido efetiva também nos dois mandatos do presidente FHC. Os gabinetes formados neste período também apresentam um alto grau de heterogeneidade. Ocorre, no entanto, que a dispersão de preferências partidárias observadas nos governos dos dois presidentes petistas é ainda maior, suscitando maior volume de controle e, como consequência, redes maiores e mais densas.

\footnotetext{
54 Ver nota 23.

${ }^{55}$ Ver nota 24.
} 
Figura 4.1. Redes de controle horizontal (PFC).
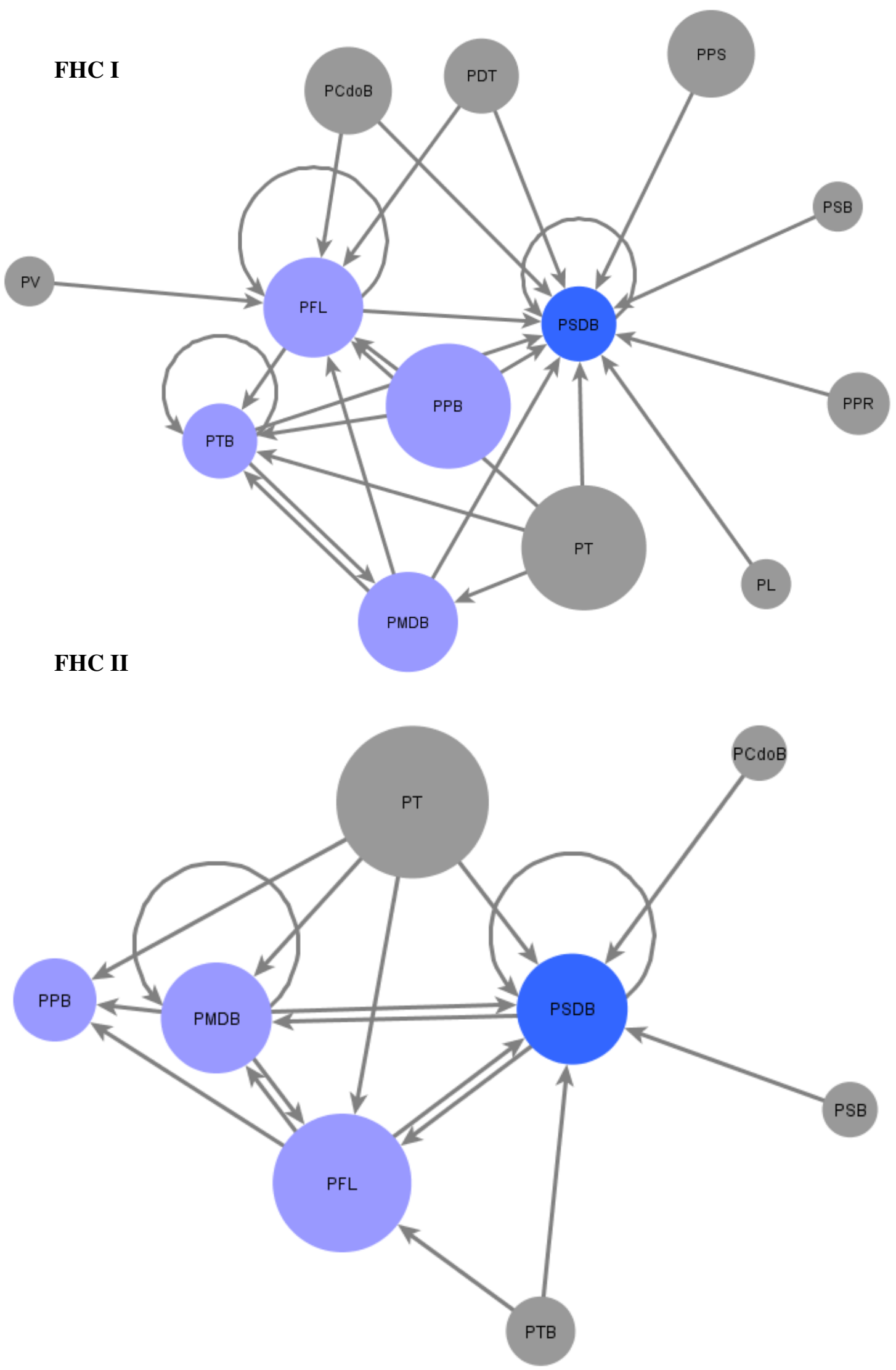
LULA I
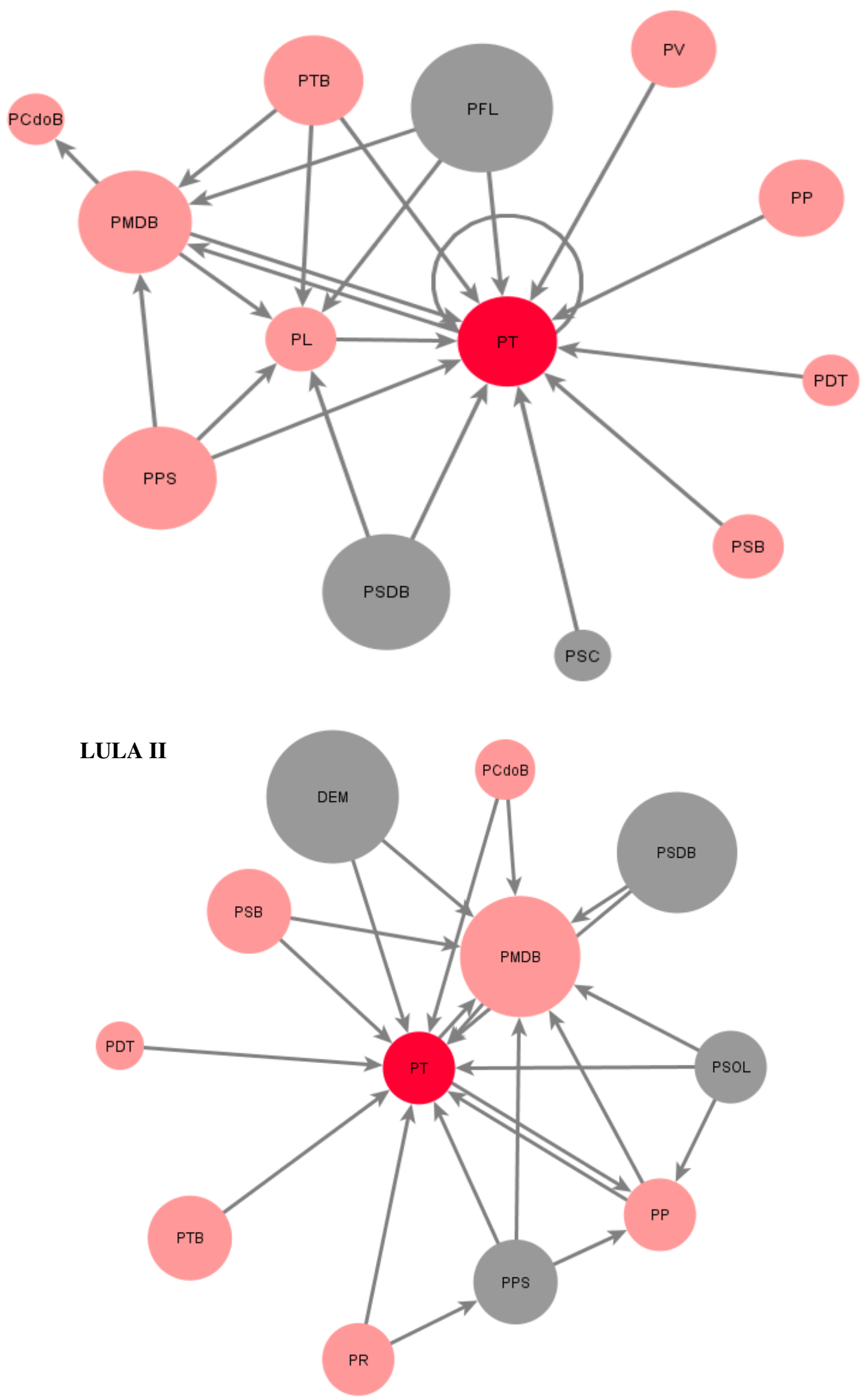

90 | Pá g i n a 


\section{DILMA I}

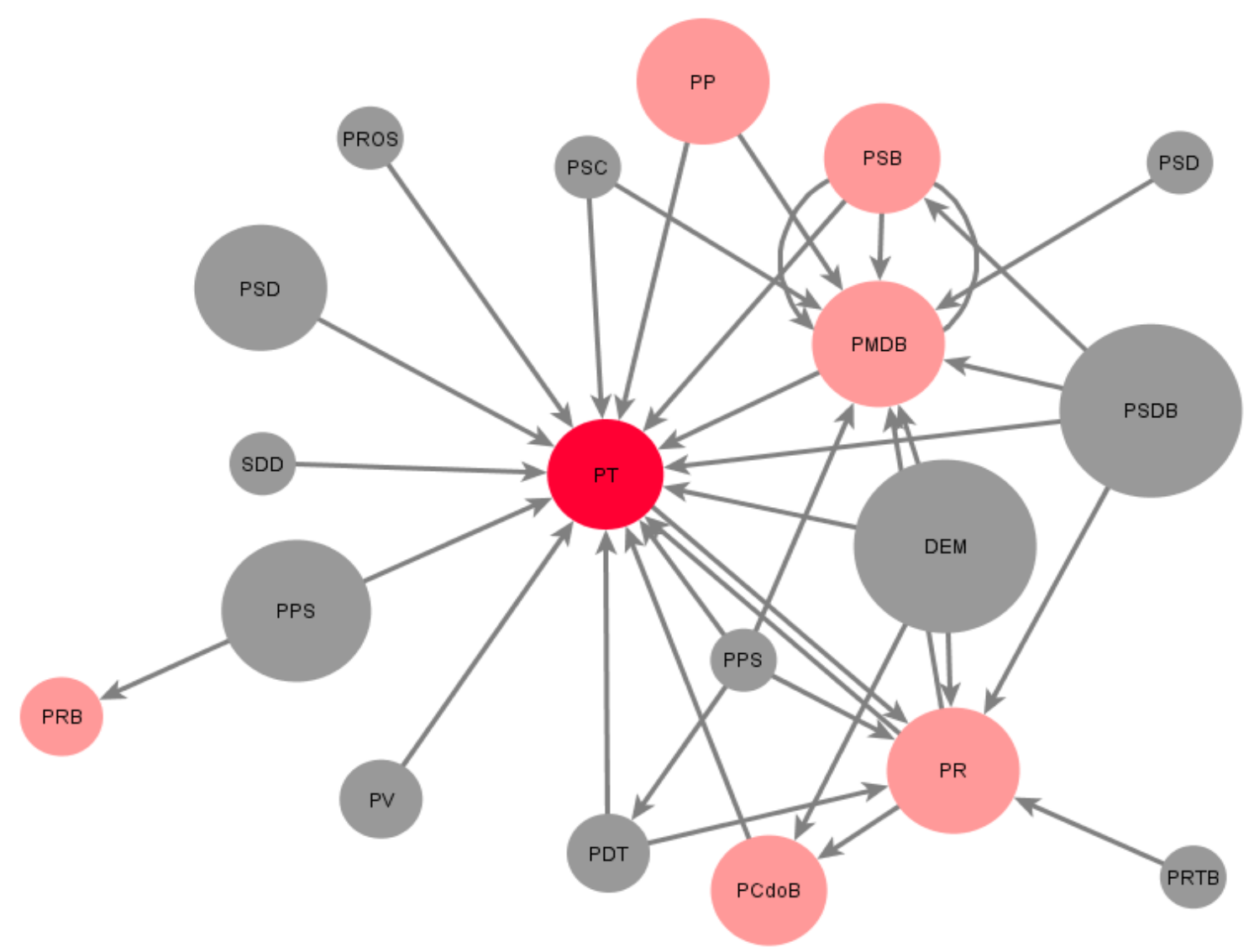

A tabela 4.2 apresenta o teste de comparação de média de proporções das categorias (governos). Os resultados revelam que a proporção de controle realizada pelos partidos da coalizão nos governos LULA (LULAI e LULAII) e DILMA é consideravelmente maior quando comparados aos dois mandatos do presidente FHC.

Tabela 4.2. Teste de Tukey (análise de variância) - proporção de Controle (PFC) executado pela coalizão em cada governo (FHC, LULA e DILMA).

\begin{tabular}{ccccccc}
\hline Categoria & Diferença (prop) & SD & T & \multicolumn{2}{c}{ p value } & \multicolumn{2}{c}{ Inter. Confiança (95\%) } \\
\hline FHCII vs FHCI & -16.40 & 0.054 & -3.03 & 0.026 & -0.3150 & -0.0130 \\
LULAII vs LULAI & -0.0384 & 0.040 & -0.94 & 0.880 & -0.1522 & 0.0753 \\
DILMAI vs LULAI & -0.0176 & 0.038 & -0.46 & 0.991 & -0.1249 & 0.0895 \\
DILMAI vs LULAII & 0.0207 & 0.045 & 0.46 & 0.991 & -0.1057 & 0.1472 \\
LULAII vs FHCI & 0.0251 & 0.050 & 0.50 & 0.987 & -0.1150 & 0.1652 \\
DILMAI vs FHCI & 0.0458 & 0.048 & 0.95 & 0.877 & -0.0889 & 0.1806 \\
LULAI vs FHCI & 0.0635 & 0.044 & 1.44 & 0.603 & -0.0594 & 0.1865 \\
LULAII vs FHCII & 0.1891 & 0.051 & 3.67 & 0.004 & 0.0455 & 0.3327 \\
DILMAI vs FHCII & 0.2098 & 0.049 & 4.23 & 0.001 & 0.0714 & 0.3483 \\
LULAI vs FHCII & 0.2275 & 0.045 & 5.00 & 0.000 & 0.1006 & 0.3545 \\
\hline
\end{tabular}

Fonte: elaborado pelo autor a partir dos dados do NECI/USP. 
Assim como no caso dos testes de comparação de média realizados com os requerimentos de informação (RIC) no capítulo anterior, as maiores diferenças verificadas estão entre as categorias dos dois governos petistas e o segundo mandato do presidente FHC (FHCII). As comparações entre as categorias dos presidentes LULA e DILMA não apresentam significância estatística, em virtude da diferença de controle realizada pela coalizão nos dois governos ser muito pequena. Nos dois casos, a proporção de controle é alta e maior que nos dois mandatos do presidente FHC embora os testes de diferenças entre as categorias dos dois governos petistas e primeiro mandato do presidente FHC não sejam estatisticamente significativos.

Em suma, tanto no caso dos requerimentos de informação (RIC) quanto no que se refere às propostas de fiscalização e controle (PFC), verifica-se um aumento das ações de controle nas ocasiões em que o governo congrega preferências mais dispersas. Decorre isso da motivação dos partidos para monitorar e influenciar as políticas públicas implementadas por seus parceiros de governo. Os partidos da coalizão não se ocupam apenas das áreas de policies a eles delegadas pelo chefe do gabinete (presidente). De forma contrária, empreendem ações de monitoramento de outras pastas do Executivo, a fim de influenciar e agregar suas preferências às políticas públicas de seu interesse.

Alguém poderia argumentar que os dois indicadores apresentados traduzem apenas preocupações gerais dos partidos com as políticas implementadas pelo Executivo. Dessa forma, um conjunto de decisões internas às burocracias dos ministérios estaria fora do radar desses atores. A fim de testar esse argumento, analisei de que forma os partidos, via atividade parlamentar, reagem às medidas tomadas no interior do Executivo que visam regulamentar o processo de implementação de políticas públicas.

Embora o Decreto Legislativo, em sua definição constitucional ${ }^{56}$, seja uma competência exclusiva do Poder Legislativo para legislar definitivamente sobre tratados, acordos ou atos internacionais que acarretem encargos ou compromissos gravosos ao patrimônio nacional, tem sido ele utilizado pelos congressistas brasileiros na tentativa de constranger as ações de regulação de políticas públicas do Executivo ${ }^{57}$. Dessa forma, os Projetos de Decreto Legislativo (PDC) podem também ser utilizados para sustar os efeitos de Decretos, Resoluções, Portarias, Atos Normativos e Medidas Provisórias.

\footnotetext{
56 Arts. 49 e $62, \S 3^{\circ}$, da Constituição Federal.

57 Sou grato a Andréa Freitas por me chamar a atenção para este aspecto.
} 
A questão que se coloca, no entanto, é se a preocupação dos partidos em influenciar as políticas públicas se estende às decisões tomadas no nível da burocracia ministerial - ou seja, aquelas decisões que não passam pelo congresso. Ademais, assumindo que os partidos exercem esse papel, em que medida os custos da delegação em gabinetes multipartidários estão relacionados com a variação das ações de controle nesta dimensão específica?

Gráfico 4.2. Variação do número de Projetos de Decreto Legislativo (PDC) em função do grau de heterogeneidade ideológica do gabinete de governo $(2000-2014)^{58}$.

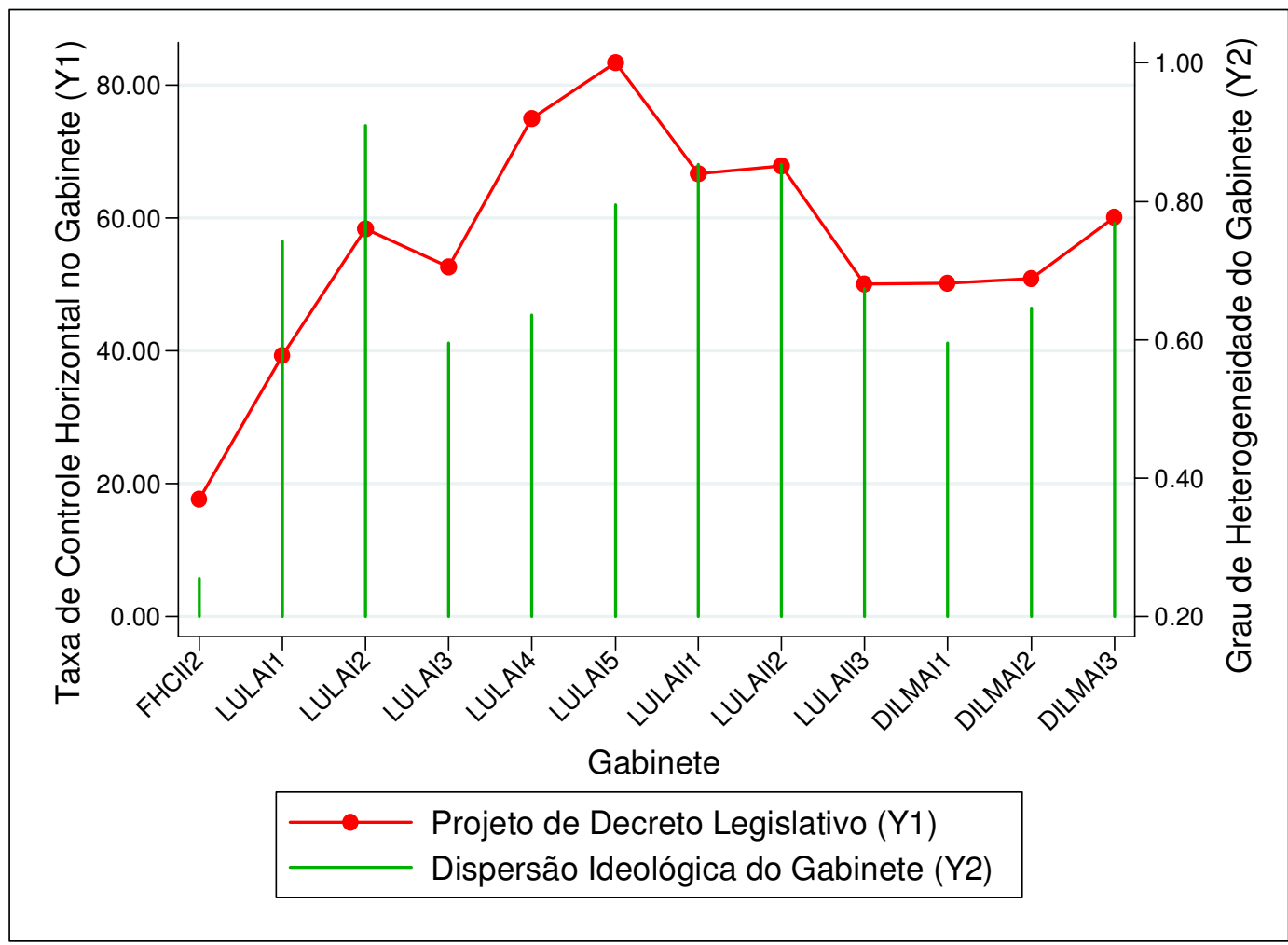

Fonte: Elaborado pelo autor a partir dos dados da Câmara dos Deputados

O gráfico 4.2 revela a taxa de controle horizontal no gabinete, calculada a partir do exame de todas as 508 propostas de projeto de decreto legislativo apresentadas entre 2000 e 2014, com o objetivo de sustar ${ }^{59}$ medidas regulamentares do Poder Executivo. A linha vermelha diz respeito à variação do número de PDC em função do grau de dispersão ideológica do gabinete (linha verde). O gráfico informa que os partidos não

\footnotetext{
58 Antes do ano 2000, nenhum PDC foi proposto com a finalidade de sustar a eficácia de algum ato de regulamentação de política pública emitido pelo Executivo. Por essa razão, os gabinetes FHCI1, FHCI2 e FHCII1 não foram considerados no gráfico 4.1.

${ }^{59}$ Foram excluídos da análise os Projetos de Decreto Legislativo apresentados com outros objetivos específicos.
} 
são indiferentes às medidas unilaterais tomadas no Executivo. Esses atores rastreiam e tentam barrar processos regulatórios que vão de encontro às suas preferências. Além disso, a correlação de $0.69^{60}$ entre as duas tendências é uma forte evidência de que estas ações de controle aumentam em gabinetes mais heterogêneos.

Isto é, os partidos controlam o processo de implementação de políticas públicas por diferentes vias. Além de monitorar o processo de execução de programas específicos ao longo da cadeia de implementação - por meio dos RIC e das PFC -, os partidos tentam sustar os efeitos de normas e procedimentos adotados pelas burocracias ministeriais que estejam em desacordo com os resultados esperados para uma determinada área de política. A tabela 4.3 informa a participação da coalizão e da oposição nas ações de controle horizontal nos governos analisados.

Os partidos da coalizão foram mais efetivos em três (75\%) das quatro redes de controle horizontal analisadas ${ }^{61}$. Com exceção da rede formada no governo LULAI, nos outros casos - FHCII, LULAII e DILMAI - os partidos integrantes do gabinete de governo foram os principais responsáveis pelas ações de controle. O que difere os governos LULA e DILMA do governo FHC é a quantidade de atores envolvidos no processo de monitoramento mútuo.

\footnotetext{
${ }^{60}$ No nível de $\mathrm{p}<0.01$.

61 Considerando a medida alternativa de tempo, o controle exercido pela coalizão foi mais efetivo em $4.740(76 \%)$ dos 6.196 dias de duração do gabinete, entre 1995 e 2014.
} 
Tabela 4.3. Descritivas das redes de controle horizontal (PDC).

\begin{tabular}{|c|c|c|c|c|c|c|c|c|c|c|}
\hline Gabinete & Duração & N. Atores & N. Relações & $\begin{array}{l}\text { N. Ações de } \\
\text { Controle }\end{array}$ & N. Coalizão & $\begin{array}{l}\text { Partidos } \\
\text { Coalizão }\end{array}$ & N. Oposiçãa & $\begin{array}{l}\text { Partidos } \\
\text { Oposição }\end{array}$ & CEC & CEO \\
\hline FHC II & 1.459 & 10 & 14 & 61 & 36 & 4 & 26 & 6 & 0,90 & 0,43 \\
\hline LULA I & 1.456 & 12 & 22 & 93 & 67 & 10 & 18 & 2 & 0,67 & 0,90 \\
\hline LULA II & 1.458 & 12 & 23 & 122 & 83 & 6 & 40 & 6 & 1,38 & 0,67 \\
\hline DILMA I & 1.823 & 19 & 45 & 173 & 80 & 8 & 94 & 11 & 1,00 & 0,85 \\
\hline
\end{tabular}

Fonte: elaborada pelo autor a partir dos dados da Câmara dos Deputados 
A tabela 4.4 apresenta todas as combinações possíveis para o teste de proporções entre as categorias (governos) analisadas. Os resultados do teste de tukey evidenciam que o maior grau de heterogeneidade no gabinete está associado com maior volume de controle horizontal intragabinete. Por essa razão, os partidos da coalizão apresentaram maior proporção de ações de controle (PDC) nos governos LULAI, LULAII e DILMAI, quando comparados com o governo FHCII. De forma complementar, vale ressaltar que os mandatos do presidente LULA apresentam as maiores proporções de controle horizontal. Neste período (2003-2010), não por acaso, observa-se a maior média de heterogeneidade do gabinete de governo desde o início da série analisada neste trabalho (1995). A figura 4.2 apresenta a representação gráfica das redes constituídas através das ações de controle empreendidas via PDC.

Tabela 4.4. Teste de Tukey (análise de variância) - proporção de Controle (PDC) executado pela coalizão em cada governo (FHC, LULA e DILMA).

\begin{tabular}{ccccccc}
\hline Categoria & $\begin{array}{c}\text { Diferença } \\
\text { (prop) }\end{array}$ & SD & T & p value & \multicolumn{2}{c}{$\begin{array}{c}\text { Inter. Confiança } \\
\text { (95\%) }\end{array}$} \\
\hline DILMA I vs LULA I & -10.17 & 0.1581 & -64.35 & 0.000 & -10.62 & -9.72 \\
DILMAI vs LULA II & -6.13 & 0.1403 & -43.72 & 0.000 & -6.53 & -5.73 \\
LULA II vs LULA I & -4.03 & 0.1628 & -24.80 & 0.000 & -4.49 & -3.57 \\
DILMA I vs FHC II & 20.79 & 0.1477 & 140.74 & 0.000 & 20.37 & 21.20 \\
LULA II vs FHC II & 26.92 & 0.1527 & 176.26 & 0.000 & 26.49 & 27.35 \\
LULA I vs FHC II & 30.96 & 0.1629 & 182.97 & 0.000 & 30.48 & 31.44 \\
\hline
\end{tabular}

Fonte: elaborado pelo autor a partir dos dados do NECI/USP 
Figura 4.2. Redes de controle horizontal (PDC).

FHC II

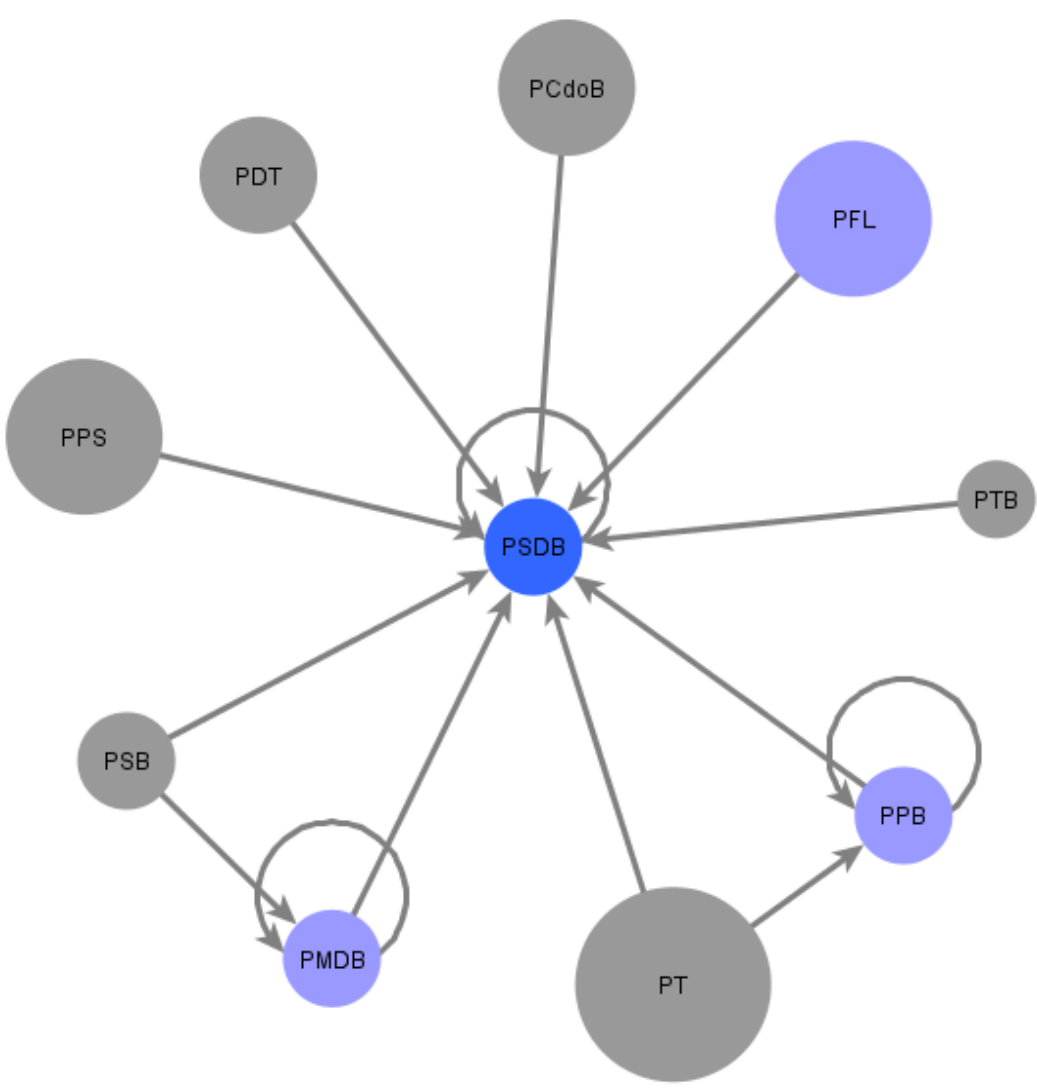

LULA I

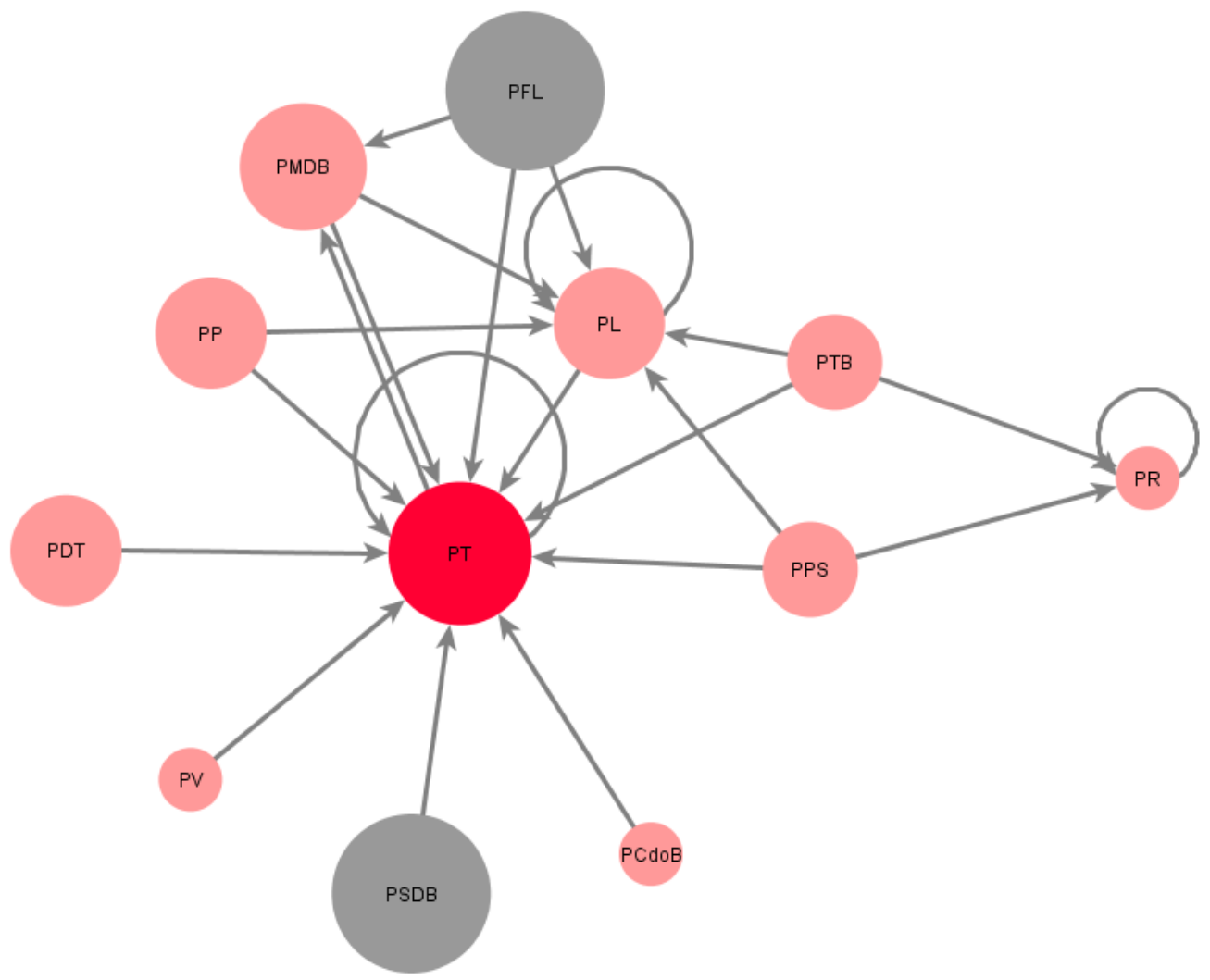



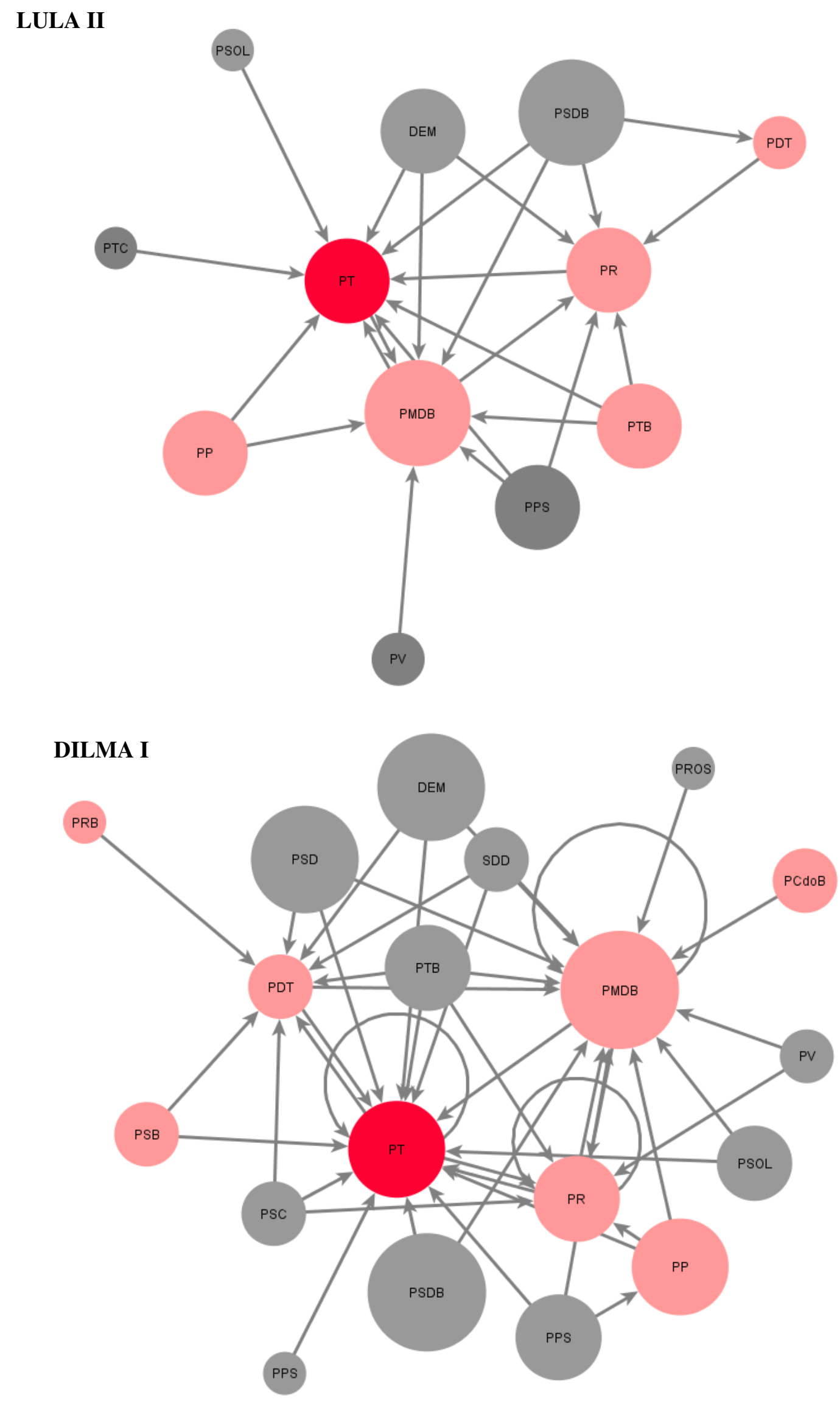

98 | Pá g i n a 
Os analistas do caso brasileiro têm sugerido que, em virtude dos custos de delegação dos governos multipartidários, o presidente adota duas importantes estratégias que visam garantir a implementação das políticas de acordo com a sua preferência: a utilização de decretos regulamentares que limitem a discricionariedade da burocracia (Vieira, 2013) e a criação de órgãos ${ }^{62}$ na estrutura da Presidência da República (Inácio, 2012; Inácio; Llanos, 2015).

Nos dois casos, os autores supracitados apresentam indícios de que a perda de informação inerente ao processo de delegação produz incentivos para que o Presidente adote medidas de controle das ações dos partidos parceiros de gabinete. Nas palavras de Vieira (2013), o uso deste tipo de regulamentação pode "minar a influência indesejada de atores políticos com posições privilegiadas sobre a burocracia pública" (p.80). Na mesma linha, Inácio (2012) argumenta que "o Presidente pode mobilizar a Presidência, enquanto organização, para controlar o uso dos poderes delegados aos partidos" (p.21).

Não obstante esses argumentos sejam plausíveis e empiricamente observáveis, são uma versão incompleta do conflito que envolve a disputa por recursos no Executivo. O partido formador não é o único ator do gabinete que, antecipando os custos e conflitos decorrentes da delegação, empreende estratégias para tentar influenciar a implementação das políticas públicas. Esses analistas pecam ao derivar para o sistema brasileiro implicações dos modelos de delegação constituídos para compreender o sistema norte-americano.

Ainda que nos dois casos o presidente seja o chefe da cadeia de delegação, no Brasil, a implementação das políticas está condicionada à composição das preferências dos diversos atores que compõem o gabinete, incentivando, como consequência, a utilização de ferramentas ex post de controle político dos parceiros da coalizão. Nesse sentido, os custos derivados da delegação se assemelham mais aos conflitos verificados nos parlamentarismos multipartidários europeus que dos custos produzidos pela composição de gabinetes unipartidários nos EUA (Araújo, 2015).

O controle horizontal via Projeto de Decreto Legislativo é a tradução literal do esforço realizado pelos partidos do gabinete para acompanhar os processos regulatórios

\footnotetext{
62 Processo que Inácio \& Llanos (2015) denominam "Institucionalização da Presidência". Originalmente, o termo foi proposto por Ragsdale \& Theis (1997)
} 
que podem afetar os resultados de políticas públicas, sejam os processos realizados nos ministérios ou nos órgãos situados na estrutura da Presidência da República. 


\section{CAPÍtULO 5 \\ Implicações teóricas e empíricas do controle da implementação de políticas públicas}

Nos capítulos anteriores, argumentei que os partidos da coalizão utilizam a fase de implementação de políticas públicas como oportunidade para influenciar as áreas e programas que lhes interessam. Essa estratégia de monitoramento se intensifica nas oportunidades em que o chefe do Executivo distribuiu os recursos do gabinete para múltiplos atores, aumentando a assimetria de informação e os custos da relação de delegação entre os integrantes do gabinete.

Neste capítulo, mostro que o controle realizado pelos partidos no momento da implementação das políticas é uma parte importante da equação que explica o que os partidos ganham quando aceitam integrar coalizões de governo no Brasil. O peso legislativo dos partidos, elemento crucial para a capacidade de agregar preferências na fase de formulação das políticas, é menos importante durante o processo de controle de implementação. Enquanto a análise isolada do processo de formulação das políticas nos leva a crer que os partidos fazem uma escolha subótima quando resolvem integrar o governo, a consideração da fase de controle de implementação nos permite enxergar o componente ótimo desta estratégia.

Assumo que o acesso à informação é uma condição sine qua non para que os partidos possam expressar suas preferências numa determinada área de policy. Na mesma linha de Diermeier et al (2008), argumento que a existência de mecanismos que induzam o compartilhamento de informação entre os membros do gabinete viabiliza a manutenção do acordo político entre os integrantes do governo. Embora partidos bem informados não necessariamente consigam agregar preferências às áreas que lhes interessam, atores com pouca informação certamente estão em condição de desvantagem na disputa por influência das policies. O controle da implementação de políticas públicas funciona como mecanismo equalizador da oferta de informação e potencializa as chances dos partidos do gabinete exercerem influência sobre as ações do Executivo.

O fato de os ministros não poderem propor políticas diretamente ao Legislativo permite que o chefe do Executivo (presidente), por meio da Casa Civil, tenha condições de realizar controle constitucional e político das propostas que nascem no gabinete. 
Aliado a tal fato, no momento de discussão das políticas no parlamento, as regras de distribuição de cargos na estrutura do legislativo privilegiam os partidos com mais cadeiras. É dizer que, tanto no momento de proposição no gabinete quanto na fase de discussão das políticas no Legislativo, o partido do presidente e os partidos da coalizão de governo com maior peso legislativo estão em posição de vantagem, uma vez que são atores mais bem informados acerca das políticas do Executivo e podem, prioritariamente, agregar suas preferências.

No entanto, como foi demonstrado nos capítulos 3 e 4 deste trabalho, o custo de obtenção de informação das políticas durante o processo de implementação é baixo. Por esse motivo, os partidos com maior peso legislativo veem-se obrigados a compartilhar informações que nas outras fases permanecem sob o controle dos maiores partidos do gabinete. Isso não significa que os novos atores informados passam a ter condições de agregar suas preferências, todavia, o controle sobre as ações de implementação dota-os de informações que podem viabilizar a consecução do objetivo de influenciar as políticas do Executivo.

\subsection{Parâmetros do modelo}

Tendo como referência o modelo proposto por Tsebelis (1998), assumo que o comportamento dos atores partidários é uma resposta ótima às condições de seu meio institucional e da estratégia adotada pelos outros atores que integram o processo decisório. Fazendo uso de todas as informações acessíveis, os partidos que integram o governo adotam estratégias que permitam maximizar o objetivo maior de influenciar políticas públicas.

Dentro dessa perspectiva, qualquer resultado que não leve à consecução desse objetivo é considerado subótimo. Todavia, assumindo um comportamento racional dos partidos, se estes atores não alcançam o resultado esperado de agregar suas preferências às políticas públicas, trata-se de uma situação em que o observador possui informação incompleta acerca do movimento desses atores nas múltiplas arenas de decisão ${ }^{63}$. Em outros termos, "o que parece subótimo a partir da perspectiva de um único jogo é na

\footnotetext{
${ }^{63} \mathrm{Na}$ perspectiva da Escolha Racional, não existe espaço para a ação subótima. A conclusão de que os atores fazem escolhas subótimas é derivada do fato de que o observador centra a sua atenção em apenas um jogo, embora o ator observado esteja envolvido em uma rede sequencial de jogos.
} 
verdade ótimo quando considerada toda a rede de jogos" (pag.27). Tal caracterização possui pelo menos duas implicações cruciais para o modelo proposto neste capítulo:

A. Jogos em múltiplas arenas possuem payoffs (ganhos) variáveis - o ator (partido) pode escolher uma estratégia aparentemente subótima numa arena (subjogo) se, depois de todas as arenas consideradas, tal estratégia maximiza os seus payoffs;

B. Os resultados observados na arena principal são dependentes das escolhas realizadas nas outras arenas de decisão, ou seja, as estratégias adotadas nas múltiplas arenas determinam os payoffs dos jogadores na arena principal.

\subsection{Implicações do modelo para a estratégia dos partidos}

Se um dado resultado político é resultante das estratégias adotadas pelos autores em múltiplas arenas, a tarefa mais básica é justamente definir quais as arenas importam para que este resultado possa ser observado adequadamente. Existem duas principais arenas onde os atores podem expressar suas preferências: [1] o gabinete - onde as políticas são propostas e formuladas em seu formato embrionário -; e [2] o parlamento onde as propostas de políticas podem ser influenciadas pelos partidos no momento da [i] formulação e na fase de [ii] controle de implementação das políticas públicas.

O gabinete é a principal arena quando queremos compreender o que os partidos ganham quando aceitam integrar coalizões. Isso é uma decorrência dos partidos representados no gabinete serem privilegiados no momento da distribuição de recursos para a implementação de políticas - observando a contribuição de cada ator em números de cadeiras na arena legislativa - e do fato de o gabinete ser a arena seminal de processamento de preferências dos distintos atores que integram o Executivo. Apesar disso, os payoffs dos partidos nesta arena são também determinados pelas ações adotadas pelos atores na arena parlamentar, nas fases de formulação e controle de implementação das políticas públicas. Como consequência, a estratégia dos partidos em integrar o governo só pode ser julgada ótima se as consequências dos lances dos jogadores (partidos) em todas estas arenas são consideradas.

A figura 5.1 ilustra uma cadeia de interações entre $n$ partidos nas duas arenas Gabinete [1] e Parlamento [2] - em que os partidos podem expressar as suas preferências. As setas bidirecionais indicam as interações entre os $n$ atores (partidos) que integram as duas arenas, no momento de proposição [1] e formulação das políticas 
públicas [2]. Esta representação esquemática dá uma ideia da complexidade que significa observar de maneira simultânea um jogo de múltiplas arenas.

Figura 5.1. Cadeia de interações entre $n$ partidos que integram o gabinete.

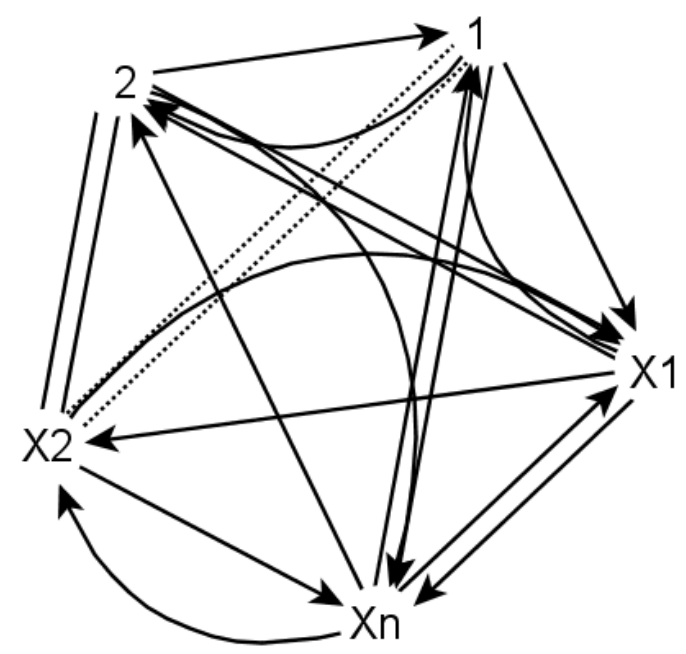

Fonte: elaborado pelo autor.

Embora desejável, operacionalmente não é possível observar conjuntamente os resultados de $n$ atores partidários em $n$ arenas de processamento de preferências. As interações podem ocorrer simultaneamente entre todos os partidos envolvidos, dentro da mesma arena ou entre arenas distintas. A alternativa viável é investigar a interação entre os partidos a partir de subjogos, de modo que os resultados das estratégias empreendidas pelos jogadores em cada arena possam ser observados separadamente, conquanto não de forma independente ${ }^{64}$.

A figura 5.2 representa graficamente uma sequência de interações entre $n$ jogadores (partidos) numa arena decisória qualquer. Não obstante esta forma esquemática inviabilize a investigação das interações que se processam entre arenas, torna possível observar o resultado das estratégias adotadas pelos partidos em cada jogo. Isto é, tendo em vista que os payoffs dos partidos na arena principal são resultantes das estratégias adotadas em cada subjogo, é possível mostrar por que uma dada estratégia $\delta$ pode ser considerada ótima.

\footnotetext{
${ }^{64}$ Os resultados de um subjogo (arena) sempre afetam os resultados dos outros subjogos (arenas). Numa rede de jogos e barganhas sequencias, a estratégia dos atores numa dada arena varia em função dos resultados obtidos nos jogos anteriores.
} 
Figura 5.2. Cadeia de interações entre $n$ partidos que integram o gabinete
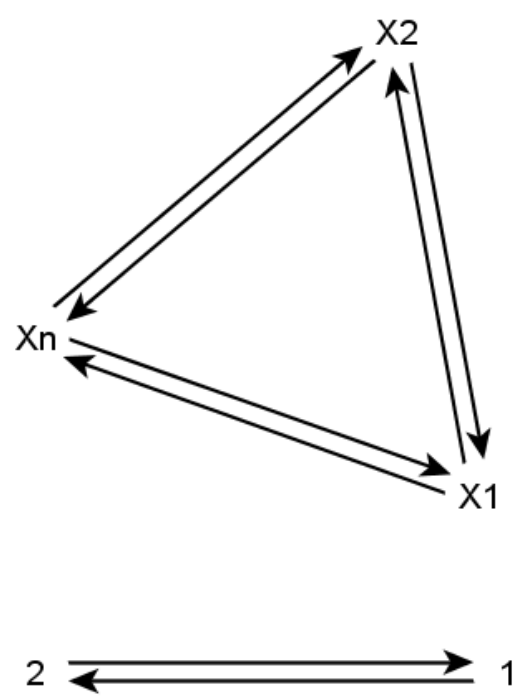

Fonte: elaborado pelo autor.

\subsection{Partidos e coalizões de governo no Brasil: um jogo de múltiplas arenas e payoffs variáveis.}

\section{Subjogo 1 (Gabinete)}

Considero o gabinete a arena principal do jogo por duas razões:

[i]. A distribuição de recursos para policy privilegia os partidos representados no gabinete, observando a contribuição de cada ator em números de cadeiras na arena legislativa (peso legislativo);

[ii]. O gabinete é a arena seminal de processamento de preferências dos distintos atores partidários que integram o Executivo. Trata-se da primeira instância de vocalização de preferências dos coordenadores (ministros) das diferentes áreas ministeriais que podem propor $^{65}$, endossar ou manifestar desacordo às matérias que irão compor a agenda de políticas do Executivo.

Nessa arena, a melhor forma possível de medir os ganhos dos partidos é por meio da análise da influência de cada ator integrante do gabinete sobre as propostas de

\footnotetext{
${ }^{65}$ Propor ao chefe do Gabinete. No Brasil, Ministros de Estado não podem enviar diretamente ao Congresso Nacional propostas de políticas. As propostas são enviadas para a Casa Civil que realiza controle de constitucionalidade e controle de conteúdo (controle político).
} 
políticas do Executivo ${ }^{66}$. O gráfico 5.1 apresenta a proporção das propostas de políticas do Executivo que cada partido ${ }^{67}$ endossou, por meio da assinatura do projeto que seguiu para apreciação no Congresso ${ }^{68}$.

As duas barras do gráfico 5.1, expressas em porcentagem no eixo Y, medem a proporção média de cadeiras dos partidos em cada governo (verde) e a proporção de propostas de políticas do Executivo que contaram com o endosso de cada partido integrante do gabinete (preto). Trata-se de um exercício simples de equivalência. Num cenário hipotético de proporcionalidade perfeita, a participação dos partidos no gabinete deveria ser equivalente ao seu peso legislativo ${ }^{69}$, ou seja, proporcional ao número de cadeiras $^{70}$ com que o partido contribui para a coalizão de governo.

Se as duas barras são equivalentes, isto significa que um dado partido obtém um ganho relativo proporcional ao número de cadeiras com que ele contribui para a composição da coalizão de governo. Se a barra verde (média de cadeiras) é maior, indica que um dado partido obtém uma perda relativa, ou seja, o ganho é menor do que o seu peso legislativo poderia predizer.

A referência básica desse exercício de equivalência é a hipótese sugerida por Gamson (1961) e posteriormente validada empiricamente por Browne \& Franklin (1973), segundo a qual "any participant will expect others to demand from a coalition a share of the payoff proportional to the amount of resources which they contribute to a

\footnotetext{
${ }^{66}$ Foram analisadas todas as iniciativas (Medida Provisória, Projeto de Lei e Projeto de Lei Complementar) do Executivo enviadas para o congresso, entre 1995 e 2014, totalizando 1.791 matérias. Foram consideradas apenas as matérias substantivas, o que gerou a exclusão das iniciativas de abertura de crédito ao orçamento.

${ }^{67}$ Os ministros técnicos foram considerados como sendo da cota do partido formador.

${ }^{68}$ A contabilização do número de endossos dos partidos é realizada a partir do exame das exposições de motivos - justificativa do Executivo para a apresentação de algum projeto ao Legislativo. Cada um desses projetos pode ser assinado por vários ministros. A influência dos partidos nas políticas do Executivo é medida, portanto, pela quantidade de projetos que um dado partido endossou através da assinatura dos seus ministros.

${ }^{69}$ A partir dos valores padronizados da proporção de cadeiras com que cada legenda contribuiu para a composição da coalizão de governo, entre 1995 e 2014, os partidos foram enquadrados nas categorias baixo (acima de um desvio padrão negativo), médio (entre 0 e 0.80 desvio padrão negativo ou positivo) ou alto (acima de um desvio padrão positivo) peso legislativo. A padronização dos valores em Z-scores é dada por $(x-\mu / \sigma)$. Foram considerados todos os partidos que ocuparam o gabinete pelo menos uma vez, em algum dos mandatos dos presidentes FHC, LULA e DILMA. A tabela com a classificação de cada partido pode ser consultada no apêndice $\mathbf{G}$ deste trabalho.

${ }^{70}$ O cálculo do peso legislativo considera o número de cadeiras dos partidos da coalizão de governo na Câmara dos Deputados.
} 
coalition $^{71 "}$ (p.376). Apesar disso, não considero razoável a principal implicação desse postulado, a saber, a de que os partidos pequenos obtêm maiores ganhos do que os partidos grandes representados no gabinete. Essa é uma consequência de um modelo estático de barganha legislativa, centrado apenas numa dimensão da distribuição de recursos no gabinete (Ansolabehere; Snyder; Strauss; Ting, 2005) e testado por medidas que desconsideram a saliência dos ministérios e as barganhas sequenciais entre os atores (Warwick; Druckman, 2001, 2006).

A realização de experimentos utilizando os modelos não cooperativos de barganha (non-cooperative bargaing models) tem produzido resultados diversos (Fréchette; Kagel; Morelli, 2005). O modelo não cooperativo proposto por Baron \& Farejohn (1989), por exemplo, postula que existe um viés na distribuição de portfólios em favor do partido formador do gabinete ${ }^{72}$. Isso porque o partido do chefe do Executivo (o first mover) oferece apenas a parcela mínima de benefícios para os partidos do Legislativo, ou seja, uma cota de recursos suficiente para garantir a formação do governo e viabilizar uma minimal winning coalitions ${ }^{73}$.

A principal crítica que pode ser feita ao modelo proposto por Baron \& Farejohn (1989), reside no fato de estes autores assumirem que as barganhas entre os atores são derivadas de uma motivação exclusivamente office-seeking dos partidos representados no Legislativo (Morelli, 1999). A segunda geração de modelos não cooperativos não desconsiderou completamente este tipo de incentivo, mas acoplou em suas análises as barganhas derivadas das preferências por policy dos partidos (Austen Smith; Banks, 1988; Baron, 1991; Crombez, 1996; Diermeier; Merlo, 1998).

Deste grupo, o trabalho de Austen Smith \& Banks (1988) é, sem nenhuma dúvida, o mais proeminente. Estes autores apresentam um modelo em que os partidos do gabinete estão dispostos num espaço de disputa por influência sobre as políticas. Nesse contexto, a influência do peso legislativo na distribuição de recursos faz com que os policy outcomes estejam mais próximos das preferências dos maiores partidos do gabinete. Esse resultado é derivado da presunção de que o controle dos ministérios

\footnotetext{
71 Para a análise de outros trabalhos que testam a hipótese de Gamson (1961) ver Browne \& Frendreis (1980), Schofield \& Laver (1985), Druckman \& Roberts (2003) e Carroll \& Cox (2007).

72 Rubinstein (1982) e Harrington (1990) são outros exemplos de modelos não cooperativos de barganha legislativa.

${ }^{73}$ Nos termos propostos por Riker (1962).
} 
determina a capacidade de influência sobre os assuntos (políticas) do governo. Em outros termos, o controle de áreas ministeriais é um meio para conseguir agregar suas preferências às políticas do gabinete, não um fim em si mesmo.

A consideração da motivação dos partidos para influenciar as políticas implica chegar a resultados opostos ao que sugere a hipótese de Gamson (1961). As evidências empíricas que testificam a "Lei de Gamson" são derivadas de análises que consideram a distribuição de portfólios como o elemento chave do pacto político entre os partidos da coalizão de governo. Assim, tendo em vista que todos os partidos do governo são absolutamente indiferentes aos resultados das políticas, os partidos pequenos - com baixo peso legislativo - sempre obtêm maiores ganhos quando comparados aos partidos que contribuem com muitas cadeiras para a coalizão de governo ${ }^{74}$.

Quando se assume uma motivação policy-seeking dos partidos, receber cargos torna-se um meio para exercer influência sobre as políticas do Executivo. Nos termos do modelo proposto neste capítulo, a distribuição de portfólios define quais são os partidos mais informados acerca das políticas do governo e, portanto, os atores com maior capacidade de exercer influência sobre estas. Assim, em consonância com Austen Smith \& Banks (1988) e com as implicações possíveis a partir da adaptação desse modelo à barganha legislativa em sistemas presidencialistas realizada por Cheibub et al (2004), considero que os partidos penalizados com a distribuição de recursos no gabinete são aqueles que, em virtude do baixo peso legislativo, tornam-se menos capazes de obter ganhos relativos. Esses ganhos, reitero, são definidos pela capacidade de influenciar as políticas do Executivo, não pelo número de cargos que um dado partido recebe.

\footnotetext{
74 O grau de proporcionalidade na distribuição de portfólios depende do número de partidos. Quanto maior o número de pequenos partidos na coalizão de governo, menos proporcional será a distribuição. Para que isso não ocorra, é necessário que o número de pastas ministeriais acompanhe o número de partidos que participam da coalizão.
} 
Gráfico 5.1. Participação na agenda do Executivo por partido e governo (1995-2014).

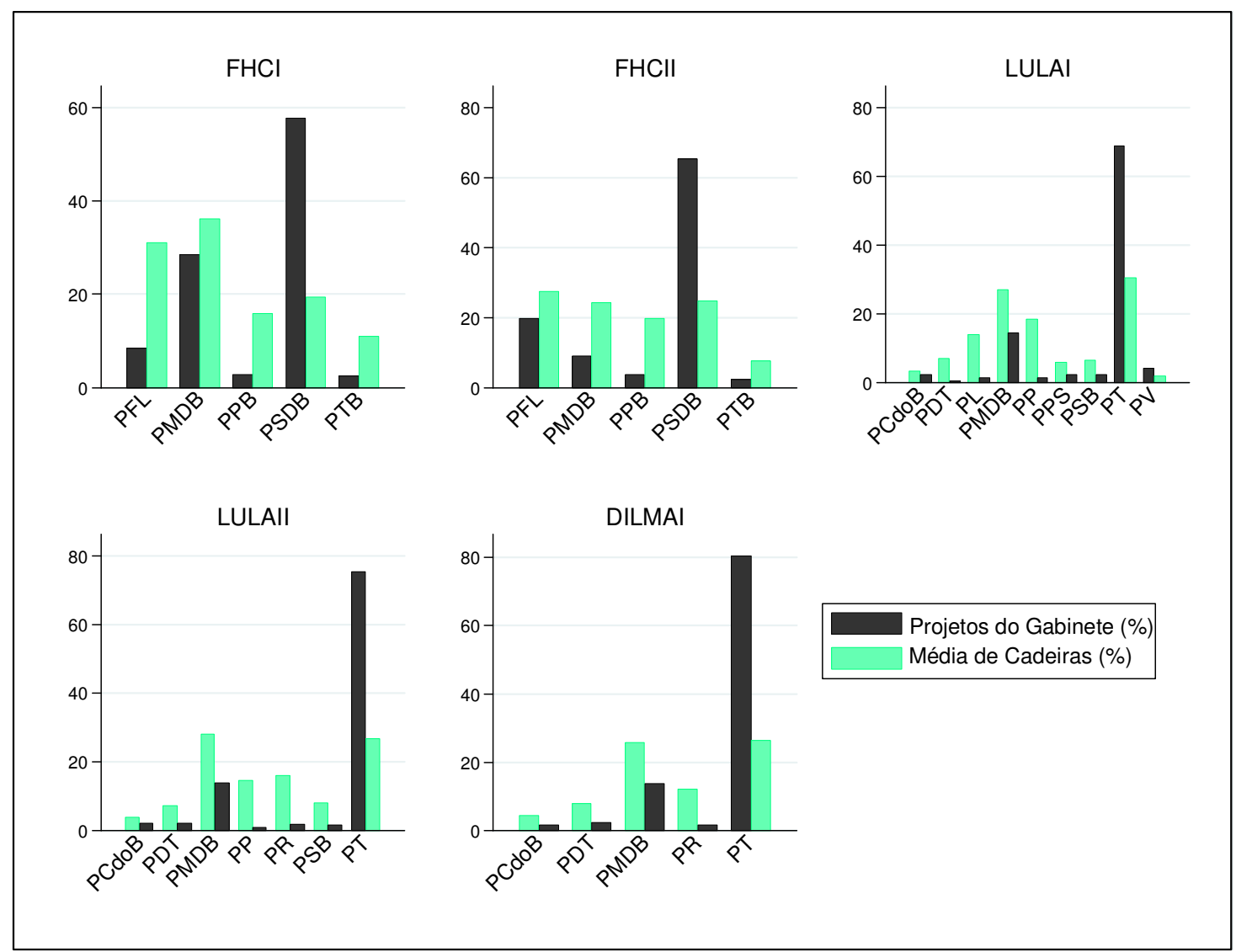

Fonte: NECI e Presidência da República.

O gráfico 5.1 informa que, nos cinco governos analisados (FHCI, FHCII, LULAI, LULAII e DILMAI), apenas o partido do presidente apresenta ganho relativo. Essa tendência acompanha as evidências apresentadas por Gaylord e Rennó (2015), segundo as quais o partido formador do gabinete é o ator com maior proeminência nas propostas que conformam a agenda de políticas do Executivo (p.260). Na mesma linha, Batista (2014) chama a atenção para quatro características que refletem o processo de formulação da agenda do governo entre 1995 e 2010: 1. aumento do número de projetos assinados apenas por membros do partido do presidente ${ }^{75} ; 2$. participação acima da média dos ministérios de coordenação ${ }^{76}$ na formulação da agenda legislativa do Executivo - não por coincidência órgãos ocupados por membros do partido do

\footnotetext{
${ }^{75}$ A autora não considera os ministros sem filiação partidária como sendo da cota do partido formador do gabinete. Isso significa que a influência do chefe do gabinete (presidente) sobre a agenda de políticas do Executivo é, muito provavelmente, ainda maior do que a reportada no referido trabalho.

${ }^{76}$ Nesta categoria, a autora considera as seguintes áreas: planejamento, fazenda, justiça e administração e reforma do Estado - este último, apenas durante o governo FHC.
} 
presidente; 3. diminuição de projetos de autoria de membros da coalizão; e 4. diminuição da participação dos ministros membros dos demais partidos da coalizão de governo no governo LULA vis-à-vis o governo FHC.

Ainda de acordo com o gráfico 5.1, apenas os partidos com maior peso legislativo - caso do PFL e PMDB nos dois mandatos do presidente FHC e do PMDB nos mandatos dos presidentes LULA e DILMA - conseguem se aproximar da relação de equivalência dada pelo seu peso legislativo. Em síntese, se essa fosse a única arena de observação, chegaríamos à indubitável conclusão de que a estratégia dos atores partidários de integrar coalizões de governo é subótima.

\section{Subjogo 2 (Parlamento - Formulação)}

A fase de discussão das políticas no parlamento é a segunda principal arena do jogo por três razões:

[i]. Nesta dimensão, os partidos da coalizão representados no Legislativo têm a chance de agregar suas preferências às políticas propostas pelo Executivo;

[ii]. É possível reduzir os custos da assimetria de informação inerente ao processo de delegação em gabinetes multipartidários. Dessa forma, mesmo aquelas políticas que não contam com o endosso de um dado partido representado no gabinete são passíveis de alteração, em função das preferências deste ator que podem ser expressas durante o transcurso do processo legislativo;

[iii]. É possível agregar preferências às áreas de policy delegadas para outros partidos do gabinete. Os partidos podem acrescentar, alterar, ou suprimir parte do texto de uma política que lhes interessa e que tenha sido proposta por outro partido do governo.

Do ponto de vista operacional, a forma mais apropriada de verificar os ganhos dos partidos do gabinete nesta dimensão é por meio da análise da capacidade de influência destes atores no parlamento. O gráfico 5.2 apresenta a porcentagem de modificações (dispositivos) realizadas pelos partidos da coalizão nos projetos oriundos do Executivo ${ }^{77}$ durante os governos FHC e LULA (1995-2010).

\footnotetext{
${ }^{77}$ Medidas provisórias (a partir de 2001), Projetos de Lei (1995-2010) e Projetos de Lei Complementar (1995-2010). A amostra conta com 179 projetos oriundos do Executivo (21375 dispositivos), sendo 101 Medidas Provisórias (13863 dispositivos), 70 Projetos de Lei (6062 dispositivos) e 8 Projetos de Lei Complementar (1450 dispositivos).
} 
Como é possível visualizar através do gráfico 5.2, os partidos com maior peso legislativo são também aqueles que realizam o maior número de modificações nas propostas de políticas oriundas do Executivo. Por isso, nos dois governos do presidente FHC, apenas PFL, PMDB e PSDB apresentam ganhos relativos. No caso dos dois governos do presidente LULA, além de PMDB e PT concentrarem as ações de modificação das propostas de políticas, alguns partidos com bancadas médias - PP, PR, PSB e PTB - apresentam perdas relativas menores do que seus parceiros de gabinete com menor peso legislativo. Dessa forma, os partidos com poucas cadeiras, via de regra $^{78}$, apresentam perdas relativas.

Em síntese, o peso legislativo muito importa para a capacidade dos partidos agregarem preferências às propostas de políticas públicas discutidas no Congresso Nacional. Nesta arena, o partido formador não consegue blindar - como é possível no gabinete $^{79}$ - as propostas do Executivo das influências dos outros partidos da coalizão com alto peso legislativo. Isso porque o critério regimental de proporcionalidade privilegia os maiores partidos no momento da distribuição das relatorias e presidências das comissões. Assim, os partidos com as maiores bancadas têm condições de ocupar espaços importantes dentro do Legislativo, viabilizando o acesso à informação e criando oportunidades para agregar preferências. Essa é a razão do partido do presidente apresentar perdas relativas nos governos FHCII e LULAI.

Isso não significa, contudo, que o partido formador passe a desempenhar um papel marginal, mas que a proeminência deste ator observada no subjogo 1 (gabinete) não se mantém no subjogo 2 (parlamento). Se esta arena de observação fosse tomada de forma isolada, seríamos levados a concluir que a estratégia dos partidos com baixo peso legislativo de participar da coalizão de governo é subótima.

\footnotetext{
78 Com exceção do PCdoB e PSB no governo LULAI.

${ }^{79}$ Depois de formuladas as propostas nos órgãos temáticos, por meio da análise jurídica realizada pela Secretaria de Assuntos Jurídicos (SAJ) e de mérito realizada pela Secretaria de Assuntos Gerais (SAG), a Casa Civil desempenha o papel de filtrar as proposições dos diversos órgãos da estrutura do Executivo. Como assevera Batista (2014), "uma vez realizada as análises, a Casa Civil tem o poder de solicitar ao órgão propositor modificações no projeto ou recusá-lo inteiramente, tanto por motivos jurídicos quanto por motivos de mérito. Se aprovado, o projeto é enviado ao presidente para que este seja submetido ao Congresso" (p.103).
} 
Gráfico 5.2. Participação nas modificações (dispositivos) das propostas de políticas do Executivo por partido e governo (1995-2010) ${ }^{80}$.

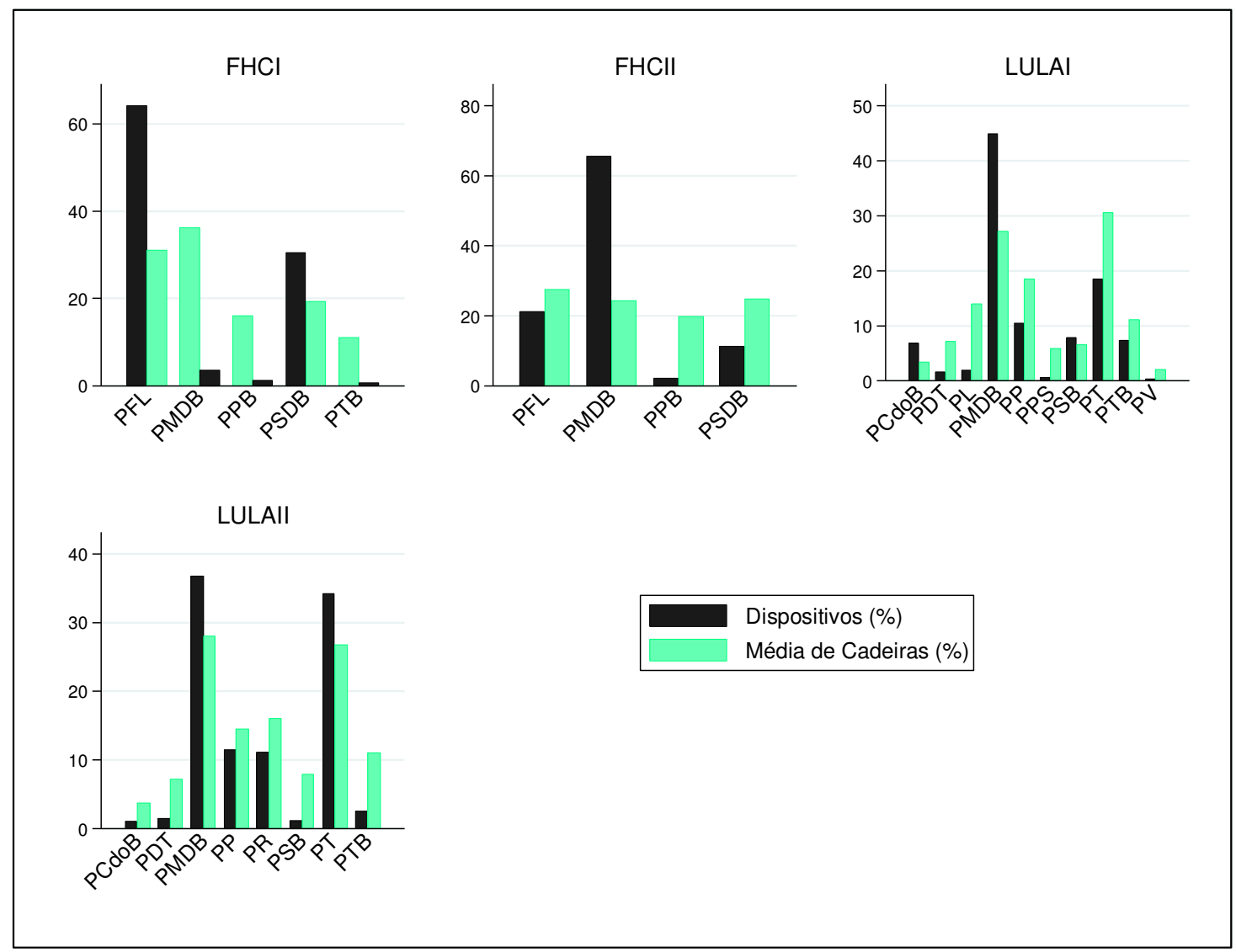

Fonte: Freitas $(2013)^{81}$ e CEBRAP.

\section{Subjogo 3 (Parlamento - Implementação)}

A fase de controle de implementação das políticas no parlamento é a terceira principal arena do jogo por três razões:

[i]. O custo dos partidos da coalizão para obtenção de informação sobre as políticas implementadas pelo Executivo é baixo. Como foi discutido no capítulo 3 deste trabalho, por meio dos requerimentos de informação, qualquer parlamentar pode

\footnotetext{
${ }^{80}$ Foram considerados apenas os projetos do Executivo que sofreram algum tipo de veto, parcial ou total. De acordo com Freitas (2013), "essas são certamente as matérias mais conflituosas ou as únicas onde o conflito entre Executivo e Legislativo é explícito e mensurável" (p.76).

${ }^{81}$ Estas informações foram originalmente organizadas por Freitas (2013), na tese intitulada "O Presidencialismo da Coalizão" (USP), e foram reproduzidas neste capítulo sob autorização. Para mais informações sobre a operacionalização e as análises realizadas pela autora utilizando a metodologia dos dispositivos acesse http://www.teses.usp.br/teses/disponiveis/8/8131/tde-08112013-102939/pt-br.php.
} 
protocolar na mesa das duas casas legislativas pedido solicitando informações a respeito do processo de implementação das políticas do governo;

[ii]. Por conseguinte, os custos da delegação em gabinetes multipartidários podem ser minorados. Por meio do controle de implementação, um dado ator pode se informar acerca das políticas do seu interesse que sejam executadas por outros partidos do gabinete, diminuindo a assimetria de informação e aumentado a sua chance de influenciar as políticas do Executivo;

[iii]. Como resultado, em função do baixo custo para obtenção de informação, a expectativa dos partidos com baixo peso legislativo de obter ganhos relativos aumenta.

Para a mensuração dos ganhos dos partidos do gabinete nesta arena, utilizo as ações de controle protocolados pelos partidos da coalizão na Câmara dos Deputados, nos governos FHC, LULA e DILMA (1995-2014) ${ }^{82}$.

Como podemos apreender do gráfico 5.3, nesta arena, os ganhos relativos em função do peso legislativo dos partidos tornam-se difusos. Esse padrão pode ser explicado por algumas razões. Em primeiro lugar, o partido do presidente (formador) apresenta perdas relativas em todos os governos analisados. Em segundo lugar, os partidos com maior peso legislativo também não registram ganhos em todo o período. Por fim, mas não menos importante, os partidos com médio e baixo peso legislativo, quando não apresentam ganhos relativos, diminuem substantivamente as perdas relativas vis-à-vis as outras arenas (subjogos).

É sintomático a esse respeito o padrão apresentado pelos partidos que contribuem com o menor número de cadeiras em cada governo ${ }^{83}$. PPB (FHC) e PCdoB (LULA e DILMA), os partidos com menores ganhos relativos nas outras dimensões, são os únicos atores que apresentam ganhos em todos os governos em que foram integrantes do gabinete. Essas são evidências de que este é um jogo de múltiplas arenas e payoffs variáveis.

\footnotetext{
${ }^{82}$ Nesse período, os partidos da coalizão protocolaram 22.688 ações de controle de implementação de políticas públicas.

${ }^{83}$ Dos partidos que permaneceram em pelo menos $80 \%$ dos gabinetes formados por cada um dos três presidentes analisados (FHC, LULA e DILMA), PPB e PCdoB foram aqueles que contribuíram com a menor quantidade de cadeiras para a coalizão de governo. Em termos percentuais, PPB e PCdoB contribuíram, em média, com 17,85 \% e 3,83\% dos membros da coalizão de governo, respectivamente.
} 
Gráfico 5.3. Participação nas ações de controle - via requerimento de informação - de implementação das políticas públicas do Executivo por partido e governo (1995-2014).

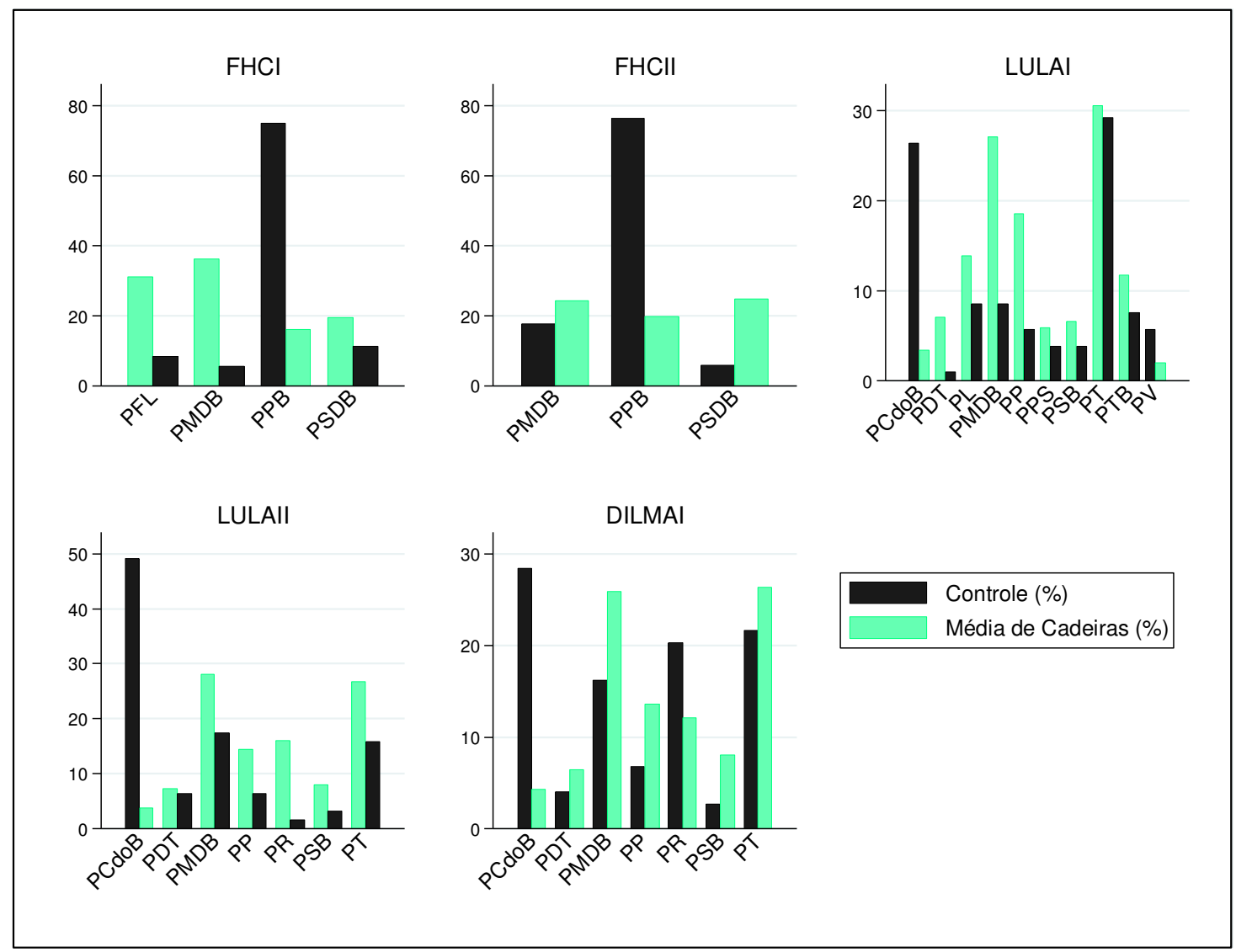

Fonte: NECI

A tabela 5.1 sumariza os payoffs de todos os partidos que integraram o gabinete no Brasil, entre 1995 e 2014, de acordo com os ganhos e perdas relativas nas três arenas discutidas neste capítulo ${ }^{84}$. Existe um padrão que pode ser verificado e que é dado pelas seguintes características:

1. Na arena A1 (gabinete), o partido formador possui proeminência na agregação de preferências e sempre apresenta ganhos relativos;

2. Na arena A1 (gabinete), os partidos com alto, médio e baixo peso legislativo sempre apresentam perdas relativas;

3. Na arena A2 (parlamento/formulação), o partido formador disputa a influência sobre as políticas com os partidos de maior peso legislativo;

84 O cálculo dos payoffs trata-se da diferença entre o ganho relativo em cada dimensão e o peso legislativo de cada partido. 
4. Na arena $\mathbf{A 2}$ (parlamento/formulação), via de regra, os partidos com alto peso legislativo apresentam ganhos relativos;

5. Na arena A3 (parlamento/implementação), o partido formador disputa a influência sobre as políticas com os partidos de médio e baixo peso legislativo;

6. Na arena $\mathbf{A 3}$ (parlamento/implementação), o partido formador sempre apresenta perdas relativas;

7. Na arena A3 (parlamento/implementação), os partidos com menor peso legislativo sempre obtêm ganhos relativos. 
Tabela 5.1. Partidos, arenas e payoffs variáveis (1995-2014).

\begin{tabular}{|c|c|c|c|c|c|c|c|c|c|c|c|c|c|c|c|}
\hline & \multicolumn{3}{|c|}{ FHCI } & \multicolumn{3}{|c|}{ FHCII } & \multicolumn{3}{|c|}{ LULAI } & \multicolumn{3}{|c|}{ LULAII } & \multicolumn{3}{|c|}{ DILMAI } \\
\hline & A1 & A2 & A3 & A1 & A2 & A3 & A1 & A2 & A3 & A1 & A2 & A3 & A1 & A2 & A3 \\
\hline \multicolumn{16}{|l|}{ Partido } \\
\hline PCdoB & - & - & - & - & - & - & $-1,12$ & 3,44 & 23,05 & $-1,51$ & $-2,69$ & 45,43 & $-2,71$ & & 45,43 \\
\hline PDT & - & - & - & - & - & - & $-6,63$ & $-5,55$ & $-6,14$ & $-4,98$ & $-5,77$ & $-0,90$ & $-5,51$ & & $-0,90$ \\
\hline PFL & $-22,57$ & 33,14 & $-22,69$ & $-7,72$ & 33,14 & $-14,03$ & - & - & - & - & - & - & - & - & - \\
\hline PL/PR & - & - & - & - & - & - & $-12,55$ & $-12,01$ & $-5,41$ & $-14,14$ & $-4,92$ & $-14,49$ & $-10,48$ & & $-14,49$ \\
\hline PMDB & $-7,72$ & 15,61 & $-30,61$ & $-15,26$ & $-32,61$ & $-6,67$ & $-12,70$ & 17,73 & $-18,62$ & $-14,15$ & 8,68 & $-10,61$ & $-12,04$ & & $-10,61$ \\
\hline $\mathrm{PPB} / \mathrm{PP}$ & $-13,13$ & $-14,76$ & 59,05 & $-16,00$ & $-14,76$ & 56,72 & $-17,21$ & $-8,12$ & $-12,90$ & $-13,54$ & $-2,99$ & $-8,16$ & $-14,37$ & & $-8,16$ \\
\hline PPS & - & - & - & - & - & - & $-3,65$ & $-5,34$ & $-2,13$ & - & - & - & - & - & - \\
\hline PRB & - & - & - & - & - & - & - & - & - & - & - & - & $-3,15$ & & $-2,79$ \\
\hline PSB & - & - & - & - & - & - & $-4,33$ & 1,20 & $-2,81$ & $-6,36$ & $-6,75$ & $-4,81$ & $-7,98$ & & $-4,81$ \\
\hline PSDB & 38,43 & 11,18 & $-8,21$ & 40,58 & 11,18 & $-18,85$ & - & - & - & - & - & - & - & - & - \\
\hline PT & - & - & - & - & - & - & 38,37 & $-12,02$ & $-1,30$ & 48,59 & 7,40 & $-10,94$ & 54,10 & & $-10,94$ \\
\hline РTB & $-8,45$ & $-10,40$ & 2,05 & - & - & - & $-5,21$ & $-3,74$ & $-4,15$ & $-2,18$ & $-8,50$ & $-2,73$ & - & - & - \\
\hline PV & - & - & - & - & - & - & $-1,01$ & $-1,74$ & 3,64 & - & - & - & - & - & - \\
\hline
\end{tabular}

Fonte: elaborada pelo autor a partir do NECI e CEBRAP. 
A análise dos ganhos dos partidos nas múltiplas arenas que envolvem a agregação de preferências às políticas públicas do Executivo, sugere que este é um jogo de barganhas sequenciais e payoffs variáveis. Embora no momento de formulação das políticas no gabinete o partido formador seja um ator proeminente, nas outras arenas (subjogos 1 e 2 ) os partidos parceiros de gabinete são capazes de diminuir a assimetria de informação e passam a ter condições de expressar suas preferências.

Gráfico 5.4. Influência dos partidos da coalizão de governo nas arenas de agregação de preferências, de acordo com o peso legislativo.
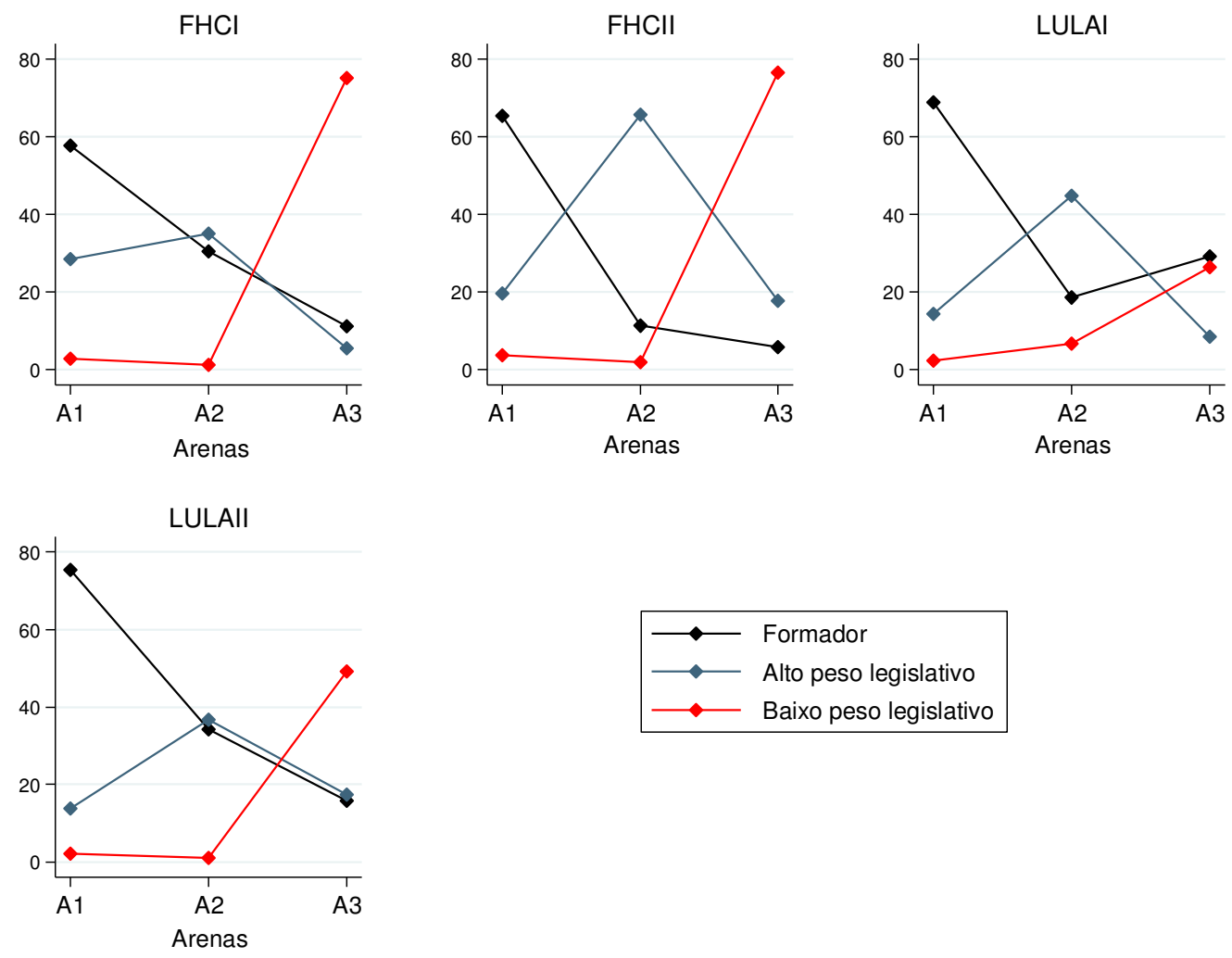

Fonte: CEBRAP e NECI.

O gráfico 5.4 apresenta a taxa de influência ${ }^{85}$ do partido formador, do partido com maior peso legislativo e do partido com menor peso legislativo ${ }^{86}$, em cada arena,

\footnotetext{
${ }^{85}$ A taxa de influência é medida pela participação percentual (representada nos gráficos 5.1, 5.2 e 5.3) dos partidos em cada uma das arenas de agregação de preferências.

${ }^{86}$ Nos dois mandatos do presidente FHC, o PMDB e PPB foram considerados, respectivamente, o partido com alto peso legislativo e o partido com baixo peso legislativo. Nos governos do presidente LULA, PMDB e PCdoB foram considerados, respectivamente, o partido com alto peso legislativo e o partido com baixo legislativo. O número de cadeiras e o peso legislativo de cada partido que ocupou o gabinete de governo no Brasil, entre 1995 e 2014, podem ser visualizados no apêndice $\mathbf{G}$ deste trabalho.
} 
nos dois mandatos dos presidentes FHC e LULA. O padrão destacado na tabela 5.1 fica ainda mais claro quando analisamos as tendências representadas nesse gráfico. A influência dos partidos nas arenas de decisão é caracterizada por uma relação de ganhos inversamente proporcionais. $\mathrm{O}$ ator que apresenta maior ganho relativo no gabinete (A1) é também aquele que menos influencia na fase de controle de implementação (A3). O contrário também é verdadeiro. $\mathrm{O}$ ator com menor ganho relativo no gabinete (A1) é aquele que apresenta a maior taxa de influência das ações de implementação de políticas públicas.

Nesta mesma linha, é sintomático o quanto o peso legislativo dos partidos está relacionado com a capacidade desses atores para influenciar as políticas públicas na fase de formulação. Em todos os governos analisados, o partido com maior peso legislativo foi o maior responsável por influenciar as propostas de políticas oriundas do Executivo. Nem mesmo nos mandatos do presidente LULA, quando a bancada do partido formador foi numericamente equivalente ao número de cadeiras do PMDB, o partido com maior peso legislativo deixou de ser o ator com maior proeminência nesta arena. Contudo, como também revela o gráfico 5.4, o partido com alto peso legislativo apresenta uma baixa taxa de influência na arena de controle de implementação (A3).

Isso significa que o objetivo de agregar preferências às políticas do Executivo é um jogo de payoffs variáveis para os integrantes do gabinete. Nenhum dos atores partidários ganha ou perde sempre. Na fase de formulação no parlamento, o peso legislativo dos partidos com maiores bancadas impõe constrangimentos ao partido formador, fazendo com que outras preferências tenham que ser necessariamente incorporadas às políticas públicas. Paralelamente, o controle de implementação das políticas serve principalmente aos interesses dos partidos com médio e baixo peso legislativo. Estes atores passam a ter condições de revindicar informações sobre as políticas do seu interesse, antes monopolizadas pelo partido formador e/ou os partidos responsáveis pelas áreas de policies.

Não obstante o controle de implementação ser, per se, apenas uma garantia de redução da assimetria de informação, é uma forma efetiva de realinhamento de preferências. Por meio do monitoramento das ações de implementação do Executivo, os partidos do gabinete são capazes de constranger seus parceiros de governo e, mesmo aqueles partidos com baixo peso legislativo passam a ter condições de influenciar as políticas do seu interesse. 
Como podemos depreender das evidências empíricas, apenas uma análise isolada das arenas de agregação de preferências permite validar os argumentos em favor de uma atuação unilateral do chefe do gabinete. Embora o presidente possa tentar viesar o conteúdo das políticas em favor do seu próprio partido, a estabilidade de governos multipartidários está condicionada à partilha de recursos para a implementação de políticas. As prerrogativas constitucionais que o tornam poderoso não permitem que o presidente brasileiro formule, discuta e implemente políticas em detrimento das preferências dos outros atores do gabinete.

No limite, isso significa que não existe uma agenda do presidente, mas uma agenda do Executivo composta a partir de preferências de atores diversos. Se é verdade que essas preferências podem ser negligenciadas num primeiro momento (gabinete), é igualmente verossímil que os partidos integrantes do gabinete possuem instrumentos de alinhamento de preferências nos momentos posteriores (formulação e implementação). Se a formação da coalizão de governo é baseada na expectativa dos partidos de influenciar a agenda de políticas do Executivo, a sustentação deste acordo político é, necessariamente, uma função da consecução deste objetivo. 


\section{Conclusão}

A principal conclusão deste trabalho é que, no presidencialismo multipartidário brasileiro, as políticas públicas implementadas pelo Executivo são resultantes do processo de agregação de preferências dos diferentes atores partidários que integram o gabinete de governo. Essa conclusão é amparada pelas seguintes evidências empíricas apresentadas ao longo dos cinco capítulos:

1. As regras formais do processo decisório em gabinetes de governos presidencialistas não constrangem o chefe do Executivo a distribuir recursos para a implementação de políticas públicas. Dessa forma, assim como nos sistemas parlamentarista e/ou semipresidencialista, a decisão de distribuir os recursos do gabinete para policy é de natureza estritamente política;

2. Os conflitos decorrentes do processo de distribuição de recursos são expressos na arena Legislativa e se materializam sob a forma de controle das ações de implementação de políticas públicas do Executivo;

3. Os partidos formam redes de controle horizontal para monitorar as políticas que lhes interessam. A densidade dessas redes varia de acordo com a dispersão de preferências no gabinete, ou seja, em função da expectativa da perda de informação derivada da relação de delegação entre os participantes do governo;

4. De forma contrária ao que prescrevem as análises que assumem o modelo officeseeking, os partidos não são indiferentes ao conteúdo e ao resultado das políticas que lhes foram negadas pelo presidente;

5. Como a distribuição de recursos para policy privilegia o partido formador do gabinete e o seu principal parceiro - via de regra o partido com maior peso legislativo -, estes atores ocupam posição de centralidade nas redes de controle horizontal;

6. Embora os partidos que não integram o governo também apresentem ações de controle das atividades do Executivo, são os partidos da coalizão de governo os principais atores responsáveis por acompanhar a implementação das políticas públicas;

7. Ao contrário dos partidos da oposição que se concentram no monitoramento de atos ilícitos do Poder Executivo, os partidos da coalizão controlam as áreas ministeriais mais salientes, principalmente aquelas ligadas às políticas sociais e de infraestrutura, em todos os níveis (local, regional, nacional) de implementação das políticas públicas.

8. Esse padrão se mantém em todas as redes construídas, utilizando diferentes medidas de controle horizontal (RIC, PFC e PDC). 
Estas evidências validam o pressuposto assumido neste trabalho de que os partidos são motivados pelo desejo de agregar suas preferências às políticas do governo. Além disso, a análise dos mecanismos de controle de implementação das políticas públicas permite dimensionar os ganhos que os partidos obtêm ao aceitar integrar coalizão de governo no Brasil. Se o peso legislativo dos partidos é um fator determinante para a capacidade de agregação de preferências nas fases de proposição (gabinete) e formulação (parlamento) das políticas, a fase de controle de implementação, em virtude do baixo custo para o monitoramento das políticas delegadas aos parceiros de governo, produz um efeito equalizador do acesso à informação.

É dizer que os partidos com médio e baixo peso legislativo passam a ter condições de se informar acerca das políticas monopolizadas pelo partido formador e/ou os maiores partidos do gabinete. Embora a correção da assimetria de informação não garanta a consideração das preferências daqueles partidos, o controle das ações de implementação do Executivo cria um espaço de vocalização de preferências para esses atores.

É preciso ressaltar, todavia, que a opção feita neste trabalho de extrair hipóteses da teoria da delegação produz algumas limitações que devem ser consideradas. Apesar de os modelos de delegação explicarem de maneira satisfatória os conflitos derivados da delegação de competência para terceiros, pouco contribuem para entender em que medida os instrumentos de controle - decorrentes da existência de conflitos entre os participantes do governo - são efetivos para a implementação de políticas de acordo com as preferências do Executivo. Isto é, esses trabalhos focam nos padrões e estratégias de delegação em detrimento de análises que observem substantivamente os resultados provenientes da interação entre o chefe do Executivo, os partidos que integram o gabinete e a burocracia (Huber; Shipan, 2007).

Dessa forma, as análises que partem das estratégias utilizadas por agentes e principals para a redução da assimetria de informação - [i]. decretos regulamentares (Epstein; O'halloran, 1999; Bawn, 1997; Huber; Shipan, 2002); [ii]. centralização presidencial (Howell; Lewis, 2002; Rudalevige; Lewis, 2005; Moe, 1985); [iii]. politização do alto escalão da burocracia (Moe, 1990; Lewis, 2007; Thies, 2001); [iv]. escrutínio (revisão) legislativo (McCubbins; Schwarts, 1984; Martin; Vanberg, 2004, 2011) - são inadequadas para predizer os resultados das políticas públicas. 
Em favor de uma perspectiva centrada nas arenas de decisão política, nesses modelos, não há uma medida substantiva das preferências de todos os agentes envolvidos na cadeia de implementação de uma dada política pública. Dessa forma, não é possível observar efetivamente o comportamento dos atores a partir da indução de um comportamento idealmente preferível. Em outros termos, tais análises permitem investigar em quais circunstâncias faz-se necessário controlar as ações dos atores parceiros na relação de delegação, mas não permitem deduzir se esses mecanismos de alinhamento de preferências são proficientes no sentido de garantir que o resultado de uma determinada política seja um produto destas ações de monitoramento (Luvertu; Weimer, 2009).

Faz-se necessário pensar, por exemplo, na disposição da burocracia para cooperar com os objetivos traçados por atores políticos. De acordo com Hogwood \& Gunn (1997), o ideal de burocracia racional instrumental preconizado por Max Weber se sustenta apenas se a etapa de implementação de uma política pública for ignorada. Além do alto grau de autonomia e discricionariedade dos burocratas responsáveis por executar as políticas (Lipsky, 1993), é preciso considerar o fato de que a tomada de decisão desses agentes pode ser embasada por objetivos diferentes daqueles preconizados pelo chefe da cadeia de delegação (Heclo, 1977).

Ademais, os policy outputs são explicados não apenas pelas estratégias dos atores que ocupam as arenas de decisão política, mas pela interação entre inputs sociais e os aspectos relacionados à dinâmica estatal (Jones; Baumgartner; 2007; Sabatier, 1993). Nesse sentido, vale ressaltar os desafios relacionados à implementação de uma política de acordo com objetivos programáticos traçados.

Pressman \& Wildavsky (1984) argumentam, por exemplo, que as metas estabelecidas para as políticas públicas são inalcançáveis. Na maior parte dos casos, não se trata da falta de acordo político ou problemas de natureza financeira, mas de problemas de interdependência entre as partes envolvidas na implementação. Quanto mais longa for a cadeia de transferência de responsabilidades, mais complexa será a implementação e, portanto, mais numerosas serão as oportunidades para desvios dos objetivos iniciais. Isto é, quanto mais atores dotados de capacidade decisória estiverem presentes na cadeia de implementação, menores as chances de implementação nos moldes idealmente estabelecidos pelo governo.

Como foi demonstrado neste trabalho, os partidos controlam a implementação de políticas públicas devido à expectativa de influenciar o seu resultado. Entretanto, não 
existem garantias de que isso ocorra de fato. Entre a proposição e a implementação existe, no caso brasileiro, um grande número de atores com capacidade para alterar o resultado de uma política pública (Arretche, 2001).

Embora haja uma tendência de extrapolação dos resultados, os modelos de delegação pouco têm a dizer sobre resultados de políticas. O potencial desta abordagem reside no fato de ser possível formular hipóteses falseáveis acerca das consequências da delegação de autoridade para atores com preferências distintas. Ainda assim, mesmo que stricto sensu não seja possível falar em garantia de resultados, é possível falar satisfatoriamente sobre as expectativas, conflitos e ganhos relacionadas à formulação e implementação das políticas públicas.

O presente trabalho contribui, dessa maneira, para uma adequada compreensão dos cálculos, estratégias e conflitos que envolvem a formulação e a implementação da agenda de políticas do Executivo, concluindo que não existe nenhuma evidência de que, no arranjo institucional brasileiro, as políticas públicas sejam um produto apenas das preferências do chefe do Executivo.

O fato de não haver interdependência entre os dois Poderes nos sistemas presidencialistas não nos autoriza a realizar análises que desconsiderem a relação de cooperação entre o Executivo e o Legislativo. É dizer que o maior entendimento dos conflitos deflagrados no gabinete passa pela melhor compreensão das estratégias adotadas pelos partidos da coalizão no Legislativo.

Embora esse entendimento não seja recente e tenha sido lançado, no Brasil, pela análise seminal realizada por Figueiredo \& Limongi (1995), por muito tempo, os analistas brasileiros se contentaram com o fato de que o nosso sistema político é capaz de produzir decisões. A análise das taxas de sucesso do Executivo é apenas a ponta do iceberg de um arranjo institucional sustentado por governos de coalizão, com distintos atores partidários e múltiplas preferências. Se toda uma geração de estudiosos das instituições políticas foi forçada pela literatura comparada a mostrar que no sistema presidencialista também existem condições para a existência de democracias estáveis, o acúmulo teórico e empírico dos últimos vinte anos nos permite pensar em desenhos de pesquisa mais ambiciosos, que permitam compreender o processo de construção das decisões, as estratégias de dissolução de conflitos e os mecanismos de alinhamento de preferências em governos multipartidários.

O sistema político brasileiro não é, como sugeriu Abranches (1988), um caso discrepante nas democracias contemporâneas. O termo "Presidencialismo de Coalizão", 
cunhado pelo referido autor e equivocadamente elevado à condição de categoria analítica, apenas contribuiu para diagnósticos superficiais e mal fundamentados do funcionamento das instituições políticas brasileiras. Da mesma forma que no parlamentarismo, no presidencialismo multipartidário brasileiro, os partidos que integram o governo competem por influência na agenda de políticas do Executivo. E, a despeito das prerrogativas do presidente brasileiro para tomar decisões de forma unilateral, as políticas públicas congregam, inevitavelmente, as preferências dos vários atores partidários que assumem os riscos e custos de integrar as coalizões de governo. 


\section{Referências}

Abranches, S (1988). Presidencialismo de coalizão: o dilema institucional brasileiro. Dados, 31(1), 5-38.

Alemán, E; Tsebelis, G (2011). Political parties and government coalitions in the Americas. Journal of Politics in Latin America, 3(1), 3-28.

Amorim Neto, O (2000). Gabinetes presidenciais, ciclos eleitorais e disciplina legislativa no Brasil. Dados, 43(3), 479-519.

(2006). The presidential calculus executive policy making and cabinet formation in the Americas. Comparative Political Studies, 39(4), 415-440.

; Santos, F (2003). O segredo ineficiente revisto: o que propõem e que aprovam os deputados brasileiros. DADOS - Revista de Ciências Sociais ,Rio de Janeiro,Vol.46,n 4 , pp.661a698.

Andeweg, R (1985). The Netherlands: Cabinet Committees in a Coalition Cabinet. Unlocking the Cabinet: Cabinet Structures in Comparative Perspective London, Sage.

(2000). Ministers as double agents? The delegation process between cabinet and ministers. European Journal of Political Research, 37(3), 377-395.

Ansolabehere, S; Snyder, J. M; Strauss, A. B; Ting, M. M (2005). Voting weights and formateur advantages in the formation of coalition governments. American Journal of Political Science, 49(3), 550-563.

Araújo, V (2015). Sistemas de Governo e Controle Político da Burocracia. nº 11, Leviathan (USP) - Cadernos de Pesquisa Política.

; Silva; T; Vieira, M (2015). Constitutional Design and Decision-Making Processes in Presidential Systems: An Analysis of the President's Executive Powers Over Cabinets. Presented at 73rd Annual Conference of the Midwest Political Science Association, Chicago.

; Freitas, A; Vieira, M (2015). Parties and control over policy: The presidential logic of government formation. Presented at 73rd Annual Conference of the Midwest Political Science Association, Chicago. 
Arretche, M (2001). Uma contribuição para fazermos avaliações menos ingênuas. In: Barreira, Maria Cecília Roxo Nobre \& Carvalho, Maria do Carmo Brant (orgs.) Tendências e perspectivas na avaliação de políticas e programas sociais. São Paulo: IEE/PUC-SP, 43-56.

Austen-Smith, D; Banks, J (1988). Elections, coalitions, and legislative outcomes. American Political Science Review, 82(02), 405-422.

Axelrod, R. M (1970). Conflict of interest: A theory of divergent goals with applications to politics. Markham Pub. Co.

Baron, D. P (1991). A spatial bargaining theory of government formation in parliamentary systems. American Political Science Review, 85(01), 137-164.

; Ferejohn, J. A (1989). Bargaining in legislatures. American political science review, 83(04), 1181-1206.

Batista, M (2013). O poder no Executivo: uma análise do papel da Presidência e dos Ministérios no presidencialismo de coalizão brasileiro (1995-2010). Opinião Pública, 19(2), 449-473.

(2014). O mistério dos ministérios: a governança da coalizão no presidencialismo brasileiro. Tese de Doutorado. Universidade Federal de Pernambuco. Recuperado de http://repositorio.ufpe.br/handle/123456789/12073

Bawn, K (1995). Political control versus expertise: Congressional choices about administrative procedures. American Political Science Review, 89(01), 62-73.

Brasil. Congresso. Câmara dos Deputados (2004). Questão de Ordem 469/2004. Câmara dos Deputados: Centro de Documentação e Informação.

Brasil. Congresso. Câmara dos Deputados (2015). Regimento interno da Câmara dos Deputados (Vol. 104). Edições Câmara.

Browne, E. C; Frendreis, J. P (1980). Allocating coalition payoffs by conventional norm: an assessment of the evidence from cabinet coalition situations. American Journal of Political Science, 753-768. 
; Dreijmanis, J (1982). Government coalitions in Western democracies.

Longman Publishing Group.

; Franklin, M. N (1973). Aspects of coalition payoffs in European parliamentary democracies. American Political Science Review, 67(02), 453469.

Budge, I; Keman, H (1993). Parties and democracy: Coalition formation and government functioning in twenty states. Oxford University Press.

Carroll, R; Cox, G. W (2007). The Logic of Gamson's Law: Pre-election Coalitions and Portfolio Allocations. American Journal of Political Science, 51(2), 300-313.

; Cox, G. W (2012). Shadowing Ministers Monitoring Partners in Coalition Governments. Comparative Political Studies, 45(2), 220-236.

Chaisty, P; Cheeseman, N; Power, T (2014). Rethinking the 'presidentialism debate: conceptualizing coalitional politics in cross-regional perspective. Democratization, 21(1), 72-94.

Cheibub, J. A (2007). Presidentialism, parliamentarism, and democracy. Cambridge University Press.

; Limongi, F (2002). Democratic institutions and regime survival: Parliamentary and presidential democracies reconsidered. Annual Review of Political Science, 5(1), 151-179.

; Limongi, F (2010). From Conflict to Coordination: Perspectives on the Study of Executive-Legislative Relations. Revista Ibero-Americana de Estudos Legislativos, 1(1), 38-53.

; Przeworski, A; Saiegh, S (2004). Government Coalition under Parliamentarism and Presidentialism. British Journal of Political Science, (34), $565-587$.

; Elkins, Z; Ginsburg, T (2014). Beyond Presidentialism and Parliamentarism. British Journal of Political Science, 44(03), 515-544.

Cox, G. W (1987). The Efficient Secret: The Cabinet and the Development of Political Parties in Victorian England. Cambridge University Press. 
Crombez, C (1996). Minority governments, minimal winning coalitions and surplus majorities in parliamentary systems. European Journal of Political Research, 29(1), 1-29.

Diermeier, D; Merlo, A (1998). Government turnover in parliamentary democracies. New York University. Type-script.

, Swaab, R. I; Medvec, V. H; Kern, M. C (2008). The micro-dynamics of coalition formation. Political Research Quarterly.

Downs, A (1957). An economic theory of political action in a democracy. The journal of political economy, 135-150.

Druckman, J; Roberts, A (2003). Coalition Governance in Eastern Europe: How Portfolio Allocation Differs in Eastern and Western Europe. In annual meeting of the American Political Science Association, Philadelphia.

Elgie, R (1997). Models of Executive Politics: A Framework for the Study of Executive Power Relations in Parliamentary and Semi-presidential Regimes. Political studies, 45(2), 217-231.

(2005). From Linz to Tsebelis: three waves of presidential/parliamentary studies? Democratization, 12(1), 106-122.

(2007). What is semi-presidentialism and where is it found. Semipresidentialism outside Europe, 1-13.

Epstein, D; O'halloran, S (1999). Delegating Powers: a transaction costs politics approach to policy making under separate powers. New York: Cambridge University Press.

Figueiredo, A. C (2007). Government Coalitions in Brazilian Democracy. Brazilian Political Science Review, 1(2), 182-216.

; Limongi, F (1995). Mudança Constitucional, Desempenho do Legislativo e Consolidação Institucional. Revista Brasileira de Ciências Sociais, 29, 175-200. 
; Limongi, F (1999). Executivo e Legislativo na nova ordem constitucional. Editora FGV Rio de Janeiro.

; Limongi, F (2000). Presidential power, legislative organization, and party behavior in Brazil. Comparative Politics, 151-170.

Fréchette, G. R; Kagel, J. H; Morelli, M (2005). Gamson's Law versus non-cooperative bargaining theory. Games and Economic Behavior, 51(2), 365-390.

Freitas, A. M (2013). O presidencialismo da coalizão. Universidade de São Paulo. Recuperado de http://www.teses.usp.br/teses/disponiveis/8/8131/tde-08112013102939/en.php

Gamson, W. A (1961). A theory of coalition formation. American sociological review, 373-382.

Gaylord, S; Rennó, L (2015). Opening the Black Box: Cabinet Authorship of Legislative Proposals in a Multiparty Presidential System. Presidential Studies Quarterly, 45(2), 247-269.

Gomes, K. M. P (2008). Proposta de Fiscalização e Controle: Um Instrumento de Controle do Legislativo sobre o Executivo. Monografia. Câmara dos Deputados.

Hacker, J. S; Pierson, P (2010). Winner-take-all politics: Public policy, political organization, and the precipitous rise of top incomes in the United States. Politics \& Society, 38(2), 152-204.

Harrington, J. E (1990). The power of the proposal maker in a model of endogenous agenda formation. Public Choice, 64(1), 1-20.

Heclo, H (1977). A government of strangers: Executive politics in Washington. Brookings Institution Press.

Hogwood, B; Gunn, L (1993). Why perfect implementation is unattainable. The policy process. A reader, 2, 217-25.

Horowitz, D. L (1990). Comparing democratic systems. Journal of Democracy, 1(4), 73-79.

Howell, W; Lewis, D (2002). Agencies by Presidential Design..The Journal of Politics, vol. $64, n^{\circ} 4$. 
Huber, J. D (1998). How does cabinet instability affect political performance? Portfolio volatility and health care cost containment in parliamentary democracies. American Political Science Review, 92(03), 577-591.

; Shipan, C (2002). Deliberate Discretion? The Institutional Foundations of Bureaucratic Autonomy. Cambridge University

Press, 2002.

; Shipan, C (2007). "Politics, Delegation, and Bureaucracy." In The Oxford Handbook Of Political Economy, ed. B, 2007.Weingast, R; Wittman, D.A New York: Oxford University Press, 256-72.

Inácio, M (2012). Coalition governments and the institutional development of the Presidency in Brazil. Paper presented at Special Seminars, University of Oxford, Latin American Center.

; Llanos, M (2015). The Institutional Presidency from a Comparative Perspective: Argentina and Brazil since the 1980s. Brazilian Political Science Review, 9(1), 39-64.

; Rezende, D (2015). Partidos Legislativos e Governo de Coalizão: Controle Horizontal das Políticas Públicas. Opinião Pública, 21(2), 296-335.

Jones, B. D; Baumgartner, F. R (2007). Punctuated Equilibrium Theory: Explaining Stability and Change in Public Policymaking. Theories of the Policy Process.

Kinzo, M. D. A (2006). Partidos, eleições e democracia no Brasil pós-1985. RBCS Vol. $19 \mathrm{n}^{\circ} .54$.

Lameirão, C (2015). A Casa Civil e a gestão da coordenação política governamental no presidencialismo de coalizão brasileiro, 1995-2010. Revista Ibero-Americana de Estudos Legislativos, 4(1).

Laver, M (2008). Governmental politics and the dynamics of multiparty competition. Political research quarterly, 61(3), 532-536.

; Schofield, N (1998). Multiparty government: The politics of coalition in Europe. University of Michigan Press. 
; Shepsle, K. A (1994). Cabinet ministers and parliamentary government. Cambridge: Cambridge University Press.

; Shepsle, K. A (1996). Making and Breaking Governments: Cabinets and Legislatures in Parliamentary Democracies. New York: Cambridge University Press.

Lavertu, S; Weimer, D. L (2009). Integrating delegation into the policy theory literature. Policy Studies Journal, 37(1), 93-102.

Lemos, L. B (2005a). Controle Legislativo em Democracias Presidencialistas: Brasil e EUA em perspectiva comparada. Tese de doutorado. Brasília: UnB. (2005b). Como o Congresso Brasileiro controla o Executivo? O uso de requerimentos de informação, convocação de autoridades e propostas de fiscalização e controle: in Llanos, M; Mustapic, A.M (orgs.), Controle Parlamentar na Alemanha, na Argentina e no Brasil. Rio de Janeiro, KonradAdenauer, pp. 85-115.

; Power, T. J (2013). Determinantes do Controle Horizontal em Parlamentos Reativos: O Caso do Brasil (1988-2005). DADOS - Revista de Ciências Sociais, 56(2), 383-412.

Lewis, D. E (2007). Testing Pendleton's Premise: Do Political Appointees Make Worse Bureaucrats? The Journal of Politics, v. 69, n. 4, p. 1073-1088.

Lijphart, A (1992). Parliamentary versus presidential government. Oxford University Press.

Lipsky, M (1993). Street-level bureaucracy: An introduction. The policy process: A reader.

Limongi, F; Figueiredo, A (2005). Processo orçamentário e comportamento legislativo: emendas individuais, apoio ao Executivo e programas de governo. Dados, 48(004), 737-776.

; Figueiredo, A. C (2008). Política Orçamentária no Presidencialismo de Coalizão. Rio de Janeiro: Editora FGV. 
; Figueiredo, A (2009). Poder de agenda e políticas substantivas.

Legislativo brasileiro em perspectiva comparada. Belo Horizonte: UFMG, 77104.

Linz, J. J (1990). The perils of presidentialism. Journal of democracy, 1(1), 51-69.

Luebbert, G. M (1986). Comparative democracy: policmaking and governing coalitions in Europe and Israel. Columbia University Press.

Lupia, A. (2003). Delegation and its Perils. In Delegation and Accountability in Parliamentary Democracies. Oxford: Oxford University Press.

; McCubbins, M. D (1998). The democratic dilemma: Can citizens learn what they need to know? Cambridge University Press.

Mackintosh, J (1969). A rejoinder. The British Prime Minister.

Magar, E; Moraes, J. A (2012). Factions with clout: Presidential cabinet coalition and policy in the Uruguayan parliament. Party Politics, 18(3), 427-451.

Mainwaring, S (1993). Presidentialism, Multipartism, and Democracy The Difficult Combination. Comparative political studies, 26(2), 198-228.

; Shugart, M. S (1997). Presidentialism and democracy in Latin America. Cambridge University Press.

Martínez-Gallardo, C (2010). Inside the Cabinet: the influence of ministers in the policymaking process. In: Scarrtascini, E; Stein; M. Tommasi; A. How Democracy Works: Political Institutions, Actors, and Arenas in Latin American Policymaking, 119-146.

Martin, L. W; Vanberg, G (2004). Policing the Bargain: Coalition Government and Parliamentary Scrutiny. American Journal of Political Science, 48(1), 13-27.

; Vanberg, G (2005). Coalition policymaking and legislative review. American Political Science Review, 99(01), 93-106.

; Vanberg, G (2008). Coalition government and political communication.

Political Research Quarterly, 61(3), 502-516. 
; Vanberg, G (2011). Parliaments and coalitions: The role of legislative institutions in multiparty governance. Oxford University Press.

McCubbins, M. D (1985). The legislative design of regulatory structure. American Journal of Political Science, 721-748.

; Schwartz, T (1984). Congressional Oversight Overlooked: Policy Patrols v. Fire Alarms. American Journal of Political Science, 28: 165-179.

Melo, C. R; Anastasia, F (2005). A reforma da previdência em dois tempos. Dados, 48(2), 301-332.

; Nunes, F (2009). Ideologia e distância entre preferências: uma comparação dos governos Lagos e Lula. In Legislativo Brasileiro em perspectiva comparada ( $1^{\circ}$ ed, Vol. 1). Belo Horizonte: Editora UFMG.

Melo, M. A; Pereira, C (2013). Making Brazil Work: Checking the President in a Multiparty System. Palgrave Macmillan.

Moe, T (1985). The politicized presidency. In: The new direction in American politics, edited by John Chubb and Paul E. Peterson. Washington, DC: Brookings Institution, 235-71.

(1990). The Politics of Structural Choice: Toward a Theory of Public Bureaucracy, in : O. Williamsom (ed), Organization Theory: From Chester Barnard to the Present and Beyond. New York, Oxford University Press. 1990.

Morelli, M. (1999). Demand competition and policy compromise in legislative bargaining. American Political Science Review, 93(04), 809-820.

Moury, C (2013). Coalition Government and Party Mandate: How coalition agreements constrain ministerial action. Routledge.

Müller, W. C; Strom, K (2003). Coalition governments in western Europe. Oxford University Press.

; Bergman, T; STROM, K (2008). Coalition Theory and Cabinet Governance: An Introduction. In Cabinets and Coalition Bargaining: The 
Democratic Life Cycle in Western Europe (p. 443). Oxford: Oxford University Press.

; Strøm, K (1999). Policy, office, or votes?: how political parties in Western Europe make hard decisions. Cambridge University Press.

; STROM, K (2003). Coalition Governments in Western Europe. Oxford: Oxford University Press.

O’Donnell, G (1998). Accountabillty Horizontal e Novas Poliarquias. Lua Nova, $\mathrm{n}^{\circ} 44$. Recuperado de http://www.scielo.br/pdf/ln/n44/a03n44.

Palermo, V. (2000). Como se governa o Brasil?: o debate sobre instituições políticas e gestão de governo. Dados v.43 n.3.

Pereira, C; Mueller, B (2003). Partidos fracos na arena eleitoral e partidos fortes na arena legislativa: a conexão eleitoral no Brasil. DADOS- Revista de Ciências Sociais, Rio de Janeiro,Vol.46,n ${ }^{4}$,pp.735a771.

; Power, T. J; Raile, E (2009). Presidencialismo de coalizão e recompensas paralelas: explicando o escândalo do Mensalão. In: Inácio \& Rennó, Legislativo brasileiro em perspectiva comparada (pp. 207-234). Editora UFMG.

Power, T. J; Gasiorowski, M. J. (1997). Institutional design and democratic consolidation in the Third World. Comparative Political Studies, 30(2), 123155.

; Zucco Jr, C (2009). Estimating ideology of Brazilian Legislative parties, 1990-2005: a research communication. Latin American Research Review, 44(1), 218-246.

Pressman, J. L; Wildavsky, A. B (1984). Implementation: how great expectations in Washington are dashed in Oakland. Univ of California Press.

Pridham, G (1986). Coalitional Behaviour in Theory and Practice: an inductive model for Western Europe. Cambridge University Press.

Ragsdale, L; Theis, J (1997). The Institucionalization of The American Presidency: 1924-1992. American Journal of Political Science, 41, 1280-1318. 
Raile, E. D; Pereira, C; Power, T. J (2011). The executive toolbox: Building legislative support in a multiparty presidential regime. Political Research Quarterly.

Rennó, L; Wojcik, S (2015). The Changing Role of Ministers in the Legislative Agenda in Brazil. Revista Ibero-Americana de Estudos Legislativos, 4(1).

Riker, W. H (1962). The theory of political coalitions. Yale University Press.

Rubinstein, A (1982). Perfect equilibrium in a bargaining model. Econometrica: Journal of the Econometric Society, 97-109.

Rudalevige, A; Lewis, D (2005). Parsing the Politicized Presidency: Centralization and Politicization as Presidential Strategies for Bureaucratic Control. Paper prepared for presentation at the 2005 Annual Meeting of the American Political Science Association, Washington, DC, September 1-4.

Russell, M., Gover, D; Wollter, K (2015). Does the Executive Dominate the Westminster Legislative Process?: Six Reasons for Doubt. Parliamentary Affairs.

Sabatier, P. A (2006). Policy Change and Learning: an Advocacy Coalition Approach (theoretical lenses on public policy).

Santos, F (1997). Patronagem e poder de agenda na política brasileira. Dados, 40(3).

Sartori, G (1994). A teoria da democracia revisitada: as questões clássicas. Tradução de Dinah de Abreu Azevedo. São Paulo: Editora Ática.

(1997). Comparative constitutional engineering: an inquiry into structures, incentives, and outcomes. NYU Press.

Schofield, N (1997). Reflections: Coalition politics and representative democracy. European Journal of Political Research, 31, p.183-92.

; Laver, M (1985). Bargaining theory and portfolio payoffs in European coalition governments 1945-83. British Journal of Political Science, 15(02), $143-164$. 
Shugart, M.; Carey, J (1992). Presidents and Assemblies: Constitutional Design and Electoral Dynamics. Cambridge University Press.

Stepan, A; Skach, C (1993). Constitutional frameworks and democratic consolidation: Parliamentarianism versus presidentialism. World Politics, 46(01), 1-22.

Strom, K (1990a). Minority government and majority rule. Cambridge University Press. (1990b). A behavioral theory of competitive political parties. American journal of political science, 565-598.

; Müller, W (2010). Parliamentary Control of Coalition Governments. Annual Review Political Science, 13, 517-535.

Tsebelis, G (1995). Decision making in political systems: Veto players in presidentialism, parliamentarism, multicameralism and multipartyism. British journal of political science, 25(03), 289-325

(1998). Jogos ocultos. São Paulo: Edusp.

Thies, M (2001). Keeping Tabs on Partners: The Logic of Delegation in Coalition Governments. American Journal of Political Science, 45(3), 580-598.

Vercesi, M (2012). Cabinets and Decision-Making Processes: Re-Assessing the Literature1. Journal of Comparative politics, 5(2), 4.

Verney, D. V (1992). Parliamentary government and presidential government. Parliamentary versus presidential government, 31, 47.

Vieira, M. M (2013). Controle político da burocracia no presidencialismo de coalizão. IESP/UERJ, Rio de Janeiro.

Warwick, P. V; Druckman, J. N (2001). Portfolio salience and the proportionality of payoffs in coalition governments. British Journal of Political Science, 31(04), 627-649. 
; Druckman, J. N (2006). The portfolio allocation paradox: An investigation into the nature of a very strong but puzzling relationship. European Journal of Political Research, 45(4), 635-665.

Wasserman, S; Faust, K (1994). Social network analysis: Methods and applications (Vol. 8). Cambridge university press.

Zucco, C (2013). Legislative Coalitions in Presidential Systems: The Case of Uruguay. Latin American Politics and Society 55 (1).

; Lauderdale, B. E (2011). Distinguishing between influences on Brazilian legislative behavior. Legislative Studies Quarterly, 36(3), 363-396. 
Apêndice A - Cálculo do grau de heterogeneidade do gabinete.

Grau de Heterogeneidade do Gabinete [varia entre 0 e 1] - quanto maior $o$ valor deste indicador, maior a distância entre as preferências dos atores presentes no Gabinete.

$$
\sum_{n=1}^{n} \mid \frac{|x-x i|}{n}
$$

Onde;

$x=$ preferência (score) do partido formador;

$x i=$ preferência do partido $(\mathrm{x})$ integrante do gabinete;

$n=$ número de partidos que integram o gabinete. 
Apêndice B - Figura B.1. Redes de baixa densidade.

\section{FHCII2}
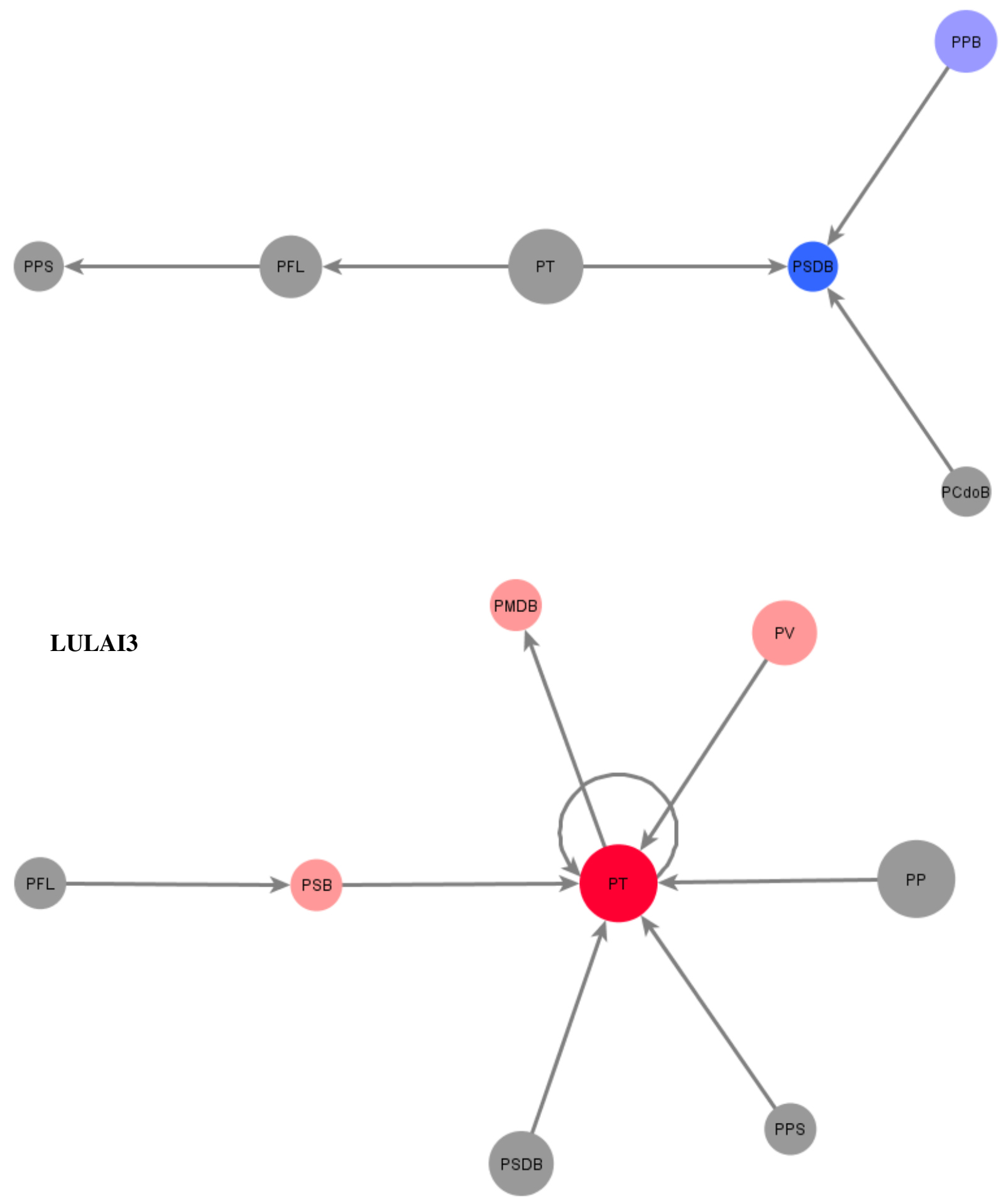

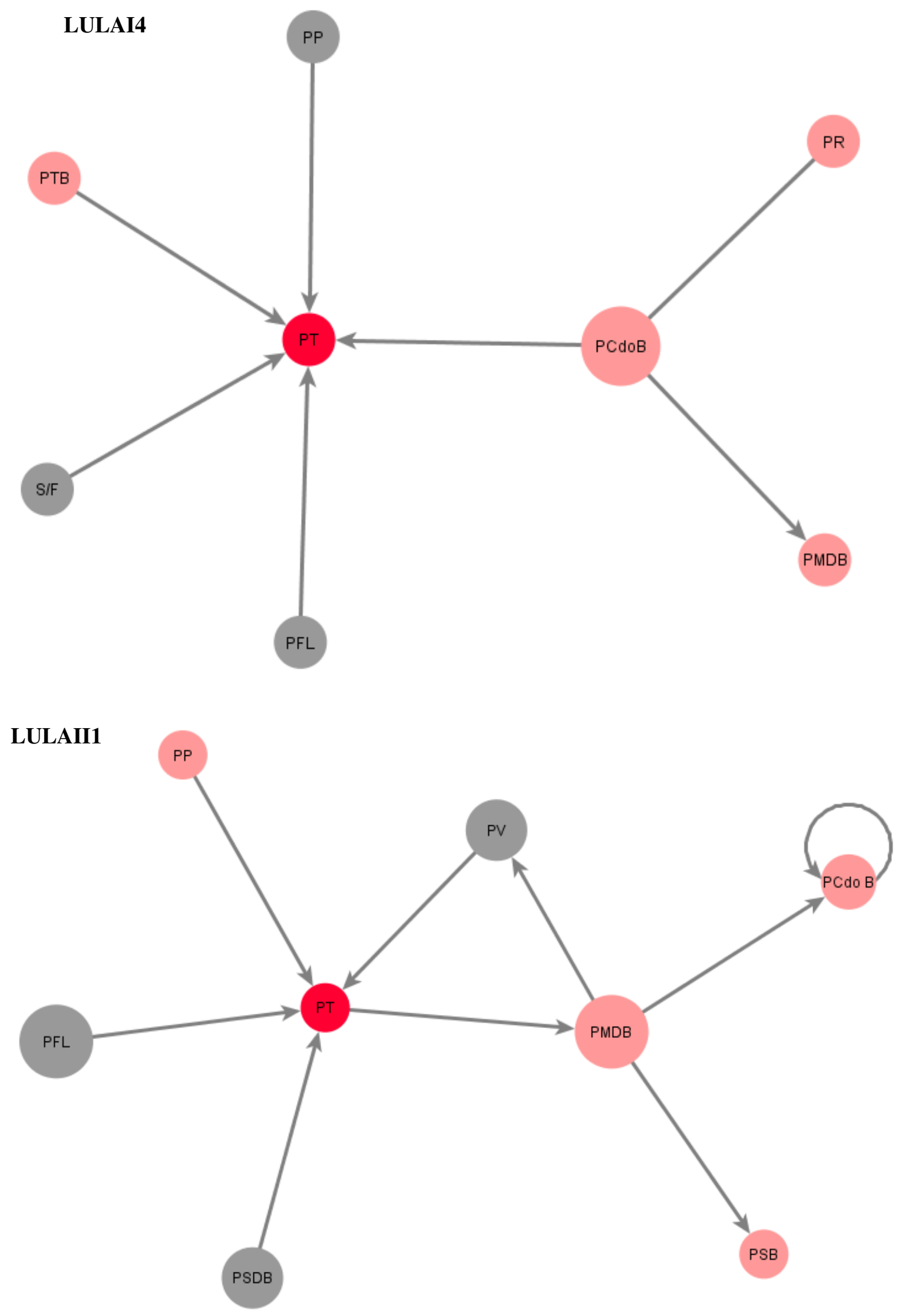
Apêndice C - Cálculo do grau de centralidade do ator na rede.

Medida padronizada do grau de centralidade dos atores partidários que integram as redes de controle intragabinete [varia entre 0 e 1]. Quanto maior $o$ valor deste indicador, maior o grau de centralidade de um dado ator na rede.

$$
C^{\prime} D\left(n_{i}\right)=\frac{X i+}{g-1} \quad C^{\prime} D\left(n_{i}\right)=\frac{\frac{\sum i j}{j}}{g-1}
$$

Onde,

xi = número relações observadas na rede;

$\mathrm{g}$ = número de relações possíveis. 
Apêndice D - Tabela D.1. Áreas de policy do partido formador e do principal parceiro do gabinete.

\begin{tabular}{|c|c|c|c|c|c|c|c|c|c|c|c|}
\hline \multicolumn{6}{|c|}{ FHCI1 } & \multicolumn{6}{|c|}{ FHCI2 } \\
\hline Formador & Áreas & $\% \mathrm{LOA}$ & $\%$ LOA & Áreas & Parceiro & Formador & Áreas & $\% \mathrm{LOA}$ & $\% \mathrm{LOA}$ & Áreas & Parceiro \\
\hline PSDB & Educação & 2,99 & 0,99 & Agricultura & PTB & PSDB & Educação & 3,31 & 1,36 & Agricultura & РТВ \\
\hline PSDB & Fazenda & 2,34 & 2,8 & Trabalho & РTB & PSDB & Fazenda & 2,89 & 3,2 & Trabalho & PTB \\
\hline PSDB & Saúde & 4,32 & & & & PSDB & Saúde & 4,66 & & & \\
\hline PSDB & Planejamento & 1,6 & & & & PSDB & Planejamento & 1,63 & & & \\
\hline PSDB & Ciên. Tecnologia & 0,27 & & & & PSDB & Ciên. Tecnologia & 0,38 & & & \\
\hline \multicolumn{6}{|c|}{ FHCII1 } & \multicolumn{6}{|c|}{ FHCII2 } \\
\hline Formador & Áreas & $\%$ LOA & $\%$ LOA & Áreas & Parceiro & Formador & Áreas & $\%$ LOA & $\%$ LOA & Áreas & Parceiro \\
\hline PSDB & Educação & 2,02 & 3,25 & Defesa & PFL & PSDB & Educação & 2,68 & 1,37 & Transportes & PMDB \\
\hline PSDB & Fazenda & 1,51 & & & & PSDB & Fazenda & 1,89 & 1,05 & Integração Nacional & PMDB \\
\hline PSDB & Saúde & 3,53 & & & & PSDB & Saúde & 4,39 & & & \\
\hline PSDB & Ciên. Tecnologia & 0,29 & & & & PSDB & Planejamento & 0,53 & & & \\
\hline \multirow[t]{3}{*}{ PSDB } & Desen. Agrário & 0,26 & & & & PSDB & Justiça & 0,57 & & & \\
\hline & & & & & & PSDB & Trabalho & 2,18 & & & \\
\hline & & & & & & PSDB & Defesa & 4,03 & & & \\
\hline
\end{tabular}




\begin{tabular}{|c|c|c|c|c|c|c|c|c|c|c|c|}
\hline \multicolumn{6}{|c|}{ LULAI1 } & \multicolumn{6}{|c|}{ LULAI2 } \\
\hline Formador & Áreas & $\% \mathrm{LOA}$ & $\%$ LOA & Áreas & Parceiro & Formador & Áreas & $\%$ LOA & $\% \mathrm{LOA}$ & Áreas & Parceiro \\
\hline PT & Educação & 1,74 & 1,1 & Transportes & PL & PT & Educação & 1,18 & 0,56 & Transportes & PL \\
\hline PT & Fazenda & 0,94 & & & & PT & Fazenda & 0,59 & 1,91 & Defesa & PL \\
\hline PT & Saúde & 2,95 & & & & $\mathrm{PT}$ & Saúde & 2,49 & & & \\
\hline PT & Trabalho & 1,51 & & & & PT & Trabalho & 1,43 & & & \\
\hline PT & Agricultura & 0,57 & & & & $\mathrm{PT}$ & Agricultura & 0,51 & & & \\
\hline PT & Defesa & 2,71 & & & & PT & Ass. Social & 0,56 & & & \\
\hline PT & Justiça & 0,42 & & & & PT & Justiça & 0,27 & & & \\
\hline PT & Minas e Energia & 0,29 & & & & $\mathrm{PT}$ & Planejamento & 0,35 & & & \\
\hline PT & Planejamento & 0,33 & & & & & & & & & \\
\hline \multicolumn{6}{|c|}{ LULAI3 } & \multicolumn{6}{|c|}{ LULAI4 } \\
\hline Formador & Áreas & $\%$ LOA & $\%$ LOA & Áreas & Parceiro & Formador & Áreas & $\% \mathrm{LOA}$ & $\%$ LOA & Áreas & Parceiro \\
\hline PT & Educação & 1,31 & 2,01 & Transportes & PL & PT & Educação & 1,31 & 2,01 & Transportes & PL \\
\hline PT & Fazenda & 0,66 & 0,57 & Defesa & PL & PT & Fazenda & 0,66 & 0,57 & Defesa & PL \\
\hline PT & Saúde & 2,52 & & & & PT & Saúde & 2,52 & & & \\
\hline PT & Trabalho & 1,45 & & & & PT & Trabalho & 1,45 & & & \\
\hline PT & Desen. Social & 0,99 & & & & PT & Desen. Social & 0,99 & & & \\
\hline PT & Agricultura & 0,33 & & & & PT & Agricultura & 0,33 & & & \\
\hline PT & Planejamento & 0,27 & & & & $\mathrm{PT}$ & Minas e Energia & 0,27 & & & \\
\hline PT & Cidades & 0,25 & & & & $\mathrm{PT}$ & Planejamento & 0,27 & & & \\
\hline PT & Ciên. Tecnologia & 0,38 & & & & PT & Cidades & 0,25 & & & \\
\hline $\mathrm{PT}$ & Minas e Energia & 0,27 & & & & $\mathrm{PT}$ & Ciên. Tecnologia & 0,38 & & & \\
\hline
\end{tabular}




\begin{tabular}{|c|c|c|c|c|c|c|c|c|c|c|c|}
\hline \multicolumn{6}{|c|}{ LULAI5 } & \multicolumn{6}{|c|}{ LULAII1 } \\
\hline Formador & Áreas & $\% \mathrm{LOA}$ & $\% \mathrm{LOA}$ & Áreas & Parceiro & Formador & Áreas & $\% \mathrm{LOA}$ & $\% \mathrm{LOA}$ & Áreas & Parceiro \\
\hline PT & Educação & 1,31 & 2,52 & Saúde & PMDB & PT & Educação & 1,75 & 3,07 & Saúde & PMDB \\
\hline PT & Fazenda & 0,66 & 2,01 & Defesa & PMDB & PT & Fazenda & 0,87 & 2,58 & Defesa & PMDB \\
\hline $\mathrm{PT}$ & Trabalho & 1,45 & 0,33 & Agricultura & PMDB & PT & Desen. Social & 1,59 & 0,29 & Comunicações & PMDB \\
\hline PT & Desen. Social & 0,99 & & & & PT & Justiça & 0,44 & 0,39 & Minas e Energia & PMDB \\
\hline PT & Justiça & 0,32 & & & & $\mathrm{PT}$ & Ciên. Tecnologia & 0,34 & 0,39 & Agricultura & PMDB \\
\hline PT & Ciên. Tecnologia & 0,32 & & & & PT & Planejamento & 0,38 & & & \\
\hline PT & Minas e Energia & 0,27 & & & & & & & & & \\
\hline $\mathrm{PT}$ & Planejamento & 0,27 & & & & & & & & & \\
\hline \multicolumn{6}{|c|}{ LULAII2 } & \multicolumn{6}{|c|}{ LULAII3 } \\
\hline Formador & Áreas & $\% \mathrm{LOA}$ & $\% \mathrm{LOA}$ & Áreas & Parceiro & Formador & Áreas & $\% \mathrm{LOA}$ & $\% \mathrm{LOA}$ & Áreas & Parceiro \\
\hline PT & Educação & 1,75 & 3,07 & Saúde & PMDB & PT & Educação & 2,56 & 3,76 & Saúde & PMDB \\
\hline PT & Fazenda & 0,87 & 2,58 & Defesa & PMDB & PT & Fazenda & 1,22 & 0,58 & Defesa & PMDB \\
\hline PT & Desen. Social & 1,59 & 0,29 & Comunicações & PMDB & PT & Desen. Social & 2,07 & 0,4 & Comunicações & PMDB \\
\hline PT & Justiça & 0,44 & 0,39 & Minas e Energia & PMDB & PT & Planejamento & 0,72 & 0,45 & Minas e Energia & PMDB \\
\hline PT & Ciên. Tecnologia & 0,34 & 0,39 & Agricultura & PMDB & PT & Justiça & 0,58 & 0,48 & Agricultura & PMDB \\
\hline \multirow[t]{2}{*}{$\mathrm{PT}$} & Planejamento & 0,38 & & & & PT & Ciên. Tecnologia & 0,38 & & & \\
\hline & & & & & & $\mathrm{PT}$ & Desen. Agrário & 0,3 & & & \\
\hline
\end{tabular}




\begin{tabular}{|c|c|c|c|c|c|c|c|c|c|c|c|}
\hline \multicolumn{6}{|c|}{ DILMAI1 } & \multicolumn{6}{|c|}{ DILMAI2 } \\
\hline Formador & Áreas & $\%$ LOA & $\%$ LOA & Áreas & Parceiro & Formador & Áreas & $\%$ LOA & $\%$ LOA & Áreas & Parceiro \\
\hline \multirow[t]{8}{*}{ PT } & Educação & 3,24 & 3,13 & Defesa & PMDB & PT & Educação & 3,45 & 3,01 & Defesa & PMDB \\
\hline & Saúde & 3,93 & 0,47 & Agricultura & PMDB & & Saúde & 4,27 & 0,48 & Agricultura & \\
\hline & Fazenda & 1,00 & 0,41 & Minas e Energia & PMDB & & Fazenda & 0,99 & 0,37 & Minas e Energia & \\
\hline & Desen. Social & 2,19 & & & & & Desen. Social & 2,56 & & & \\
\hline & Justiça & 0,83 & & & & & Justiça & 0,58 & & & \\
\hline & Planejamento & 0,57 & & & & & Planejamento & 0,38 & & & \\
\hline & & & & & & & Desen. Social & 2,56 & & & \\
\hline & & & & & & & Comunicações & 0,26 & & & \\
\hline \multicolumn{12}{|c|}{ DILMAI3 } \\
\hline Formador & Áreas & $\% \mathrm{LOA}$ & $\%$ LOA & Áreas & Parceiro & & & & & & \\
\hline \multirow[t]{10}{*}{ PT } & Educação & 3,75 & 3,07 & Defesa & PMDB & & & & & & \\
\hline & Saúde & 4,58 & 0,49 & Agricultura & PMDB & & & & & & \\
\hline & Fazenda & 1,12 & 0,42 & Integração Nacional & PMDB & & & & & & \\
\hline & Desen. Social & 2,87 & 0,5 & Minas e Energia & PMDB & & & & & & \\
\hline & Justiça & 0,54 & & & & & & & & & \\
\hline & Planejamento & 0,63 & & & & & & & & & \\
\hline & Desen. Social & 2,87 & & & & & & & & & \\
\hline & Comunicações & 0,25 & & & & & & & & & \\
\hline & Ciên. Tecnologia & 0,44 & & & & & & & & & \\
\hline & Desen. Agrário & 0,25 & & & & & & & & & \\
\hline
\end{tabular}

Fonte: CEBRAP/NECI 
Apêndice E - Tabela E.1. Exemplos dos requerimentos de informação (RIC) utilizados para compor as categorias da dimensão "Temática".

Tema Ementa

Administração Pública

Solicita Informações ao Ministério da Administração Federal e Reforma do Estado sobre Remuneração de Servidores Públicos Federais.

Solicita informações ao Senhor Ministro de Estado das Relações Exteriores sobre contratação de pessoal terceirizado na Administração Pública Federal.

Agronegócio

Solicita informações ao Senhor Presidente da Confederação da Agricultura e Pecuária do Brasil acerca da receita e da aplicação dos recursos do Serviço Nacional de Aprendizagem Rural.

Solicita informações ao Ministério da Fazenda - MF a respeito das ações implementadas para proceder à renegociação de dívidas dos produtores rurais, através dos normativos editados pelo Banco Central do Brasil.

Controle de Ilícitos

Solicita informações ao Sr. Ministro de Minas e Energia, Edison Lobão a respeito dos negócios que a Petrobras tem com a empresa OGX.

Solicita ao Ministério dos Transportes, através do Departamento Nacional de Infraestrutura Terrestre, informações sobre possíveis irregularidades nas obras de duplicação da BR-265, trecho Lavras / BR-381.

Cultura e Turismo

Solicita informações a excelentíssima Ministra da Cultura, Sra. Ana de Hollanda, sobre as atividades desenvolvidas pelo Plano Nacional de Livro e leitura no município de Sena Madureira, Estado do Acre.

Solicita informações ao Senhor Ministro de Estado da Cultura, no âmbito da Fundação Cultural Palmares acerca da política nacional de certificação de comunidades quilombolas no País.

Economia e Planejamento

Solicita informações ao Sr. Ministro da Fazenda sobre a elevação da taxa básica de juros.

Solicita informações ao Ministério da Fazenda sobre a evolução orçamentária dos gastos nos setores considerados sociais e os gastos com juros, encargos e serviços da dívida pública externa. 
Solicita informações ao Sr. Ministro da Defesa sobre projetos de obras do PAC - Programa de Aceleração do Crescimento - em aeroportos.

Solicita informações ao Senhor Ministro dos Transportes sobre o Plano Nacional de Logística e Transportes (PNLT).

Meio Ambiente

Solicita informações ao Sr. Ministro da Agricultura, Pecuária e Abastecimento, Roberto Rodrigues, sobre plantio de soja transegênica.

Solicita a Exma. Sra. Ministro do Meio Ambiente informações sobre lista de primatas brasileiros ameaçados de extinção.

Política Fiscal

Solicita informações ao Ministro da Fazenda sobre a arrecadação setorial e por regime de tributação do Imposto de Renda.

Solicita ao Senhor Ministro da Fazenda informações sobre a possibilidade de desobrigar as Caixas Escolares de apresentarem Declarações de Imposto de Renda.

Política Social

Requer informações ao Ministro da Educação, acerca da execução do Programa Nacional de Reestruturação e Aquisição de Equipamentos para a Rede Escolar Pública de Educação Infantil (Proinfância) Solicita informações ao Senhor Ministro de Estado da Saúde sobre a implantação da vacinação contra a hepatite A na rotina do Sistema Único de Saúde (SUS).

\section{Segurança Pública}

Solicita informações ao Senhor Ministro da Justiça a respeito da aplicação de recursos do Fundo Nacional de Segurança Pública.

Solicita informações ao Sr. Ministro de Estado da Justiça sobre a situação do sistema prisional brasileiro.

Fonte: Elaborado pelo autor a partir dos dados da Câmara dos Deputados 
Apêndice F - Quadro F.1. Exemplos dos requerimentos de informação (RIC) utilizados para compor as categorias da dimensão "Nível".

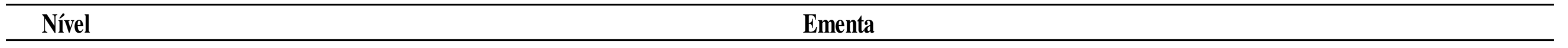

Individual

Solicita à Senhora Ministra Chefe da Casa Civil Dilma Rousseff informações pertinentes a respeito de matéria publicada no jornal 0 Globo.

Solicita informações ao Sr. Ministro-Chefe da Casa Civil sobre declarações do Senhor Presidente da República a jornalistas acerca do Governo Fernando Henrique Cardoso.

Local

Solicita ao Ministro de Estado da Saúde informações sobre denúncia de indícios de irregularidades na aplicação de recursos públicos destinados à saúde no município de Cachoeiro do Itapemirim, ES.

Solicita informações a excelentíssima Ministra da Cultura, Sra. Ana de Hollanda, sobre as atividades desenvolvidas pelo Plano Nacional de Livro e leitura no município de Xapuri, no estado do Acre.

Nacional

Requer informações ao Ministro da Educação Senhor José Henrique Paim sobre o Programa Nacional de Acesso ao Ensino Técnico e Emprego (Pronatec).

Solicita ao Senhor Ministro da Fazenda informações pertinentes as transferências e/ou repasses de recursos para a execução do Programa Minha Casa, Minha Vida - PMCMV.

Regional

Solicita ao Senhor Ministro da Educação informações sobre alocação de lanchas escolares na região Norte.

Solicita ao Senhor Ministro de Minas e Energia, no âmbito da Agência Nacional do Petróleo - ANP, informações sobre as prospecções no abastecimento do Gás Natural na região sul do País.

Setorial

Requer informações ao Sr. Ministro da Previdência Social, a respeito de cálculos e critérios atuariais de planos de benefícios da Caixa de Previdência dos Funcionários do Banco do Brasil - PREVI.

Requerimento de informações ao Ministro da Defesa sobre a Operação Amazon Guardian, que vem sendo realizada pela Organização não Governamental Greenpeace, na Amazônia. 
Apêndice G - Tabela G.1. Partidos do gabinete e peso legislativo por governo

\begin{tabular}{|c|c|c|c|c|c|c|c|}
\hline \multicolumn{3}{|c|}{ FHCI } & \multirow[b]{2}{*}{ Peso } & \multicolumn{4}{|c|}{ FHCII } \\
\hline Partido & $\%$ Cadeiras & $\mathbf{Z}$ & & Partido & $\%$ Cadeiras & $\mathbf{Z}$ & Peso \\
\hline PFL & 31,09 & 0,56 & Médio & PMDB & 31,2 & 3,00 & Alto \\
\hline PMDB & 35,17 & 1,00 & Alto & PFL & 29,32 & 2,32 & Alto \\
\hline PPB & 14,44 & $-1,17$ & Baixo & PPB & 15,75 & $-2,60$ & Baixo \\
\hline PSDB & 19,3 & $-0,66$ & Médio & PSDB & 23,73 & 0,29 & Médio \\
\hline \multicolumn{4}{|c|}{ LULAI } & \multicolumn{4}{|c|}{ LULAII } \\
\hline Partido & \% Cadeiras & $\mathbf{Z}$ & Peso & Partido & $\%$ Cadeiras & $\mathbf{Z}$ & Peso \\
\hline PCdoB & 2,82 & $-1,10$ & Baixo & PCdoB & 2,96 & $-1,28$ & Baixo \\
\hline PDT & 4,76 & $-0,80$ & Médio & PDT & 6,99 & $-0,80$ & Médio \\
\hline PL & 12,15 & 0,05 & Médio & PMDB & 27,07 & 1,27 & Alto \\
\hline PMDB & 23,36 & 1,08 & Alto & PP & 14,51 & $-0,04$ & Médio \\
\hline PP & 13,24 & 0,06 & Médio & PR & 15,08 & 0,02 & Médio \\
\hline PPS & 3,05 & $-0,97$ & Baixo & PSB & 7,58 & $-0,77$ & Médio \\
\hline PSB & 3,6 & $-0,92$ & Baixo & PT & 25,81 & 1,14 & Alto \\
\hline PT & 26,8 & 1,43 & Alto & & & & \\
\hline PTB & 8,95 & $-0,38$ & Médio & & & & \\
\hline $\mathrm{PV}$ & 1,27 & $-1,15$ & Baixo & & & & \\
\hline & DILMAI & & & & & & \\
\hline Partido & $\%$ Cadeiras & $\mathbf{Z}$ & Peso & & & & \\
\hline PCdoB & 4,32 & $-0,90$ & Baixo & & & & \\
\hline PDT & 6,43 & $-0,67$ & Médio & & & & \\
\hline PMDB & 25,86 & 1,47 & Alto & & & & \\
\hline PP & 13,59 & 0,12 & Médio & & & & \\
\hline $\mathrm{PR}$ & 12,11 & $-0,04$ & Médio & & & & \\
\hline PRB & 3,26 & $-1,01$ & Baixo & & & & \\
\hline PSB & 8,04 & $-0,49$ & Médio & & & & \\
\hline PT & 26,39 & 1,52 & Alto & & & & \\
\hline
\end{tabular}

